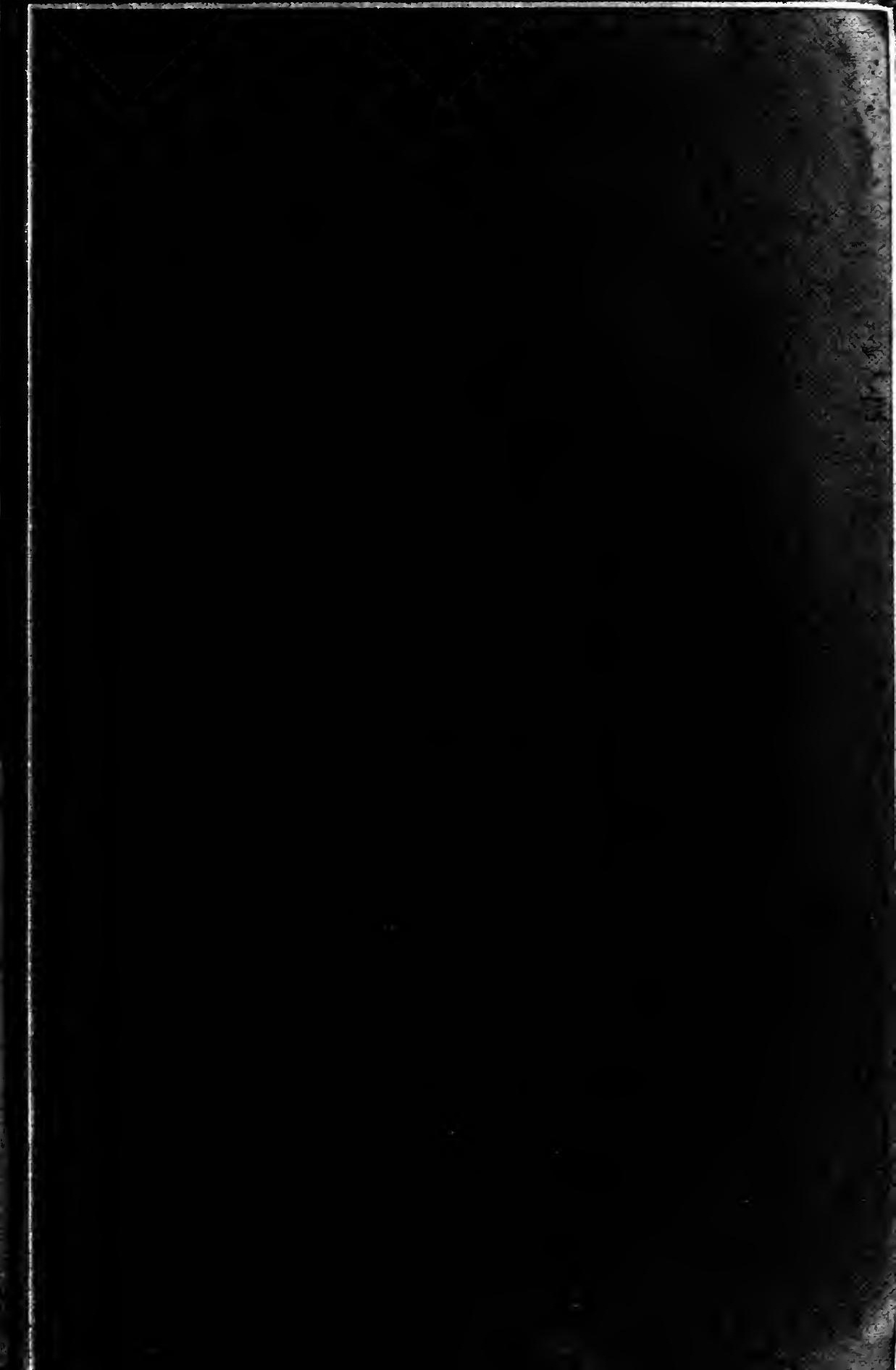




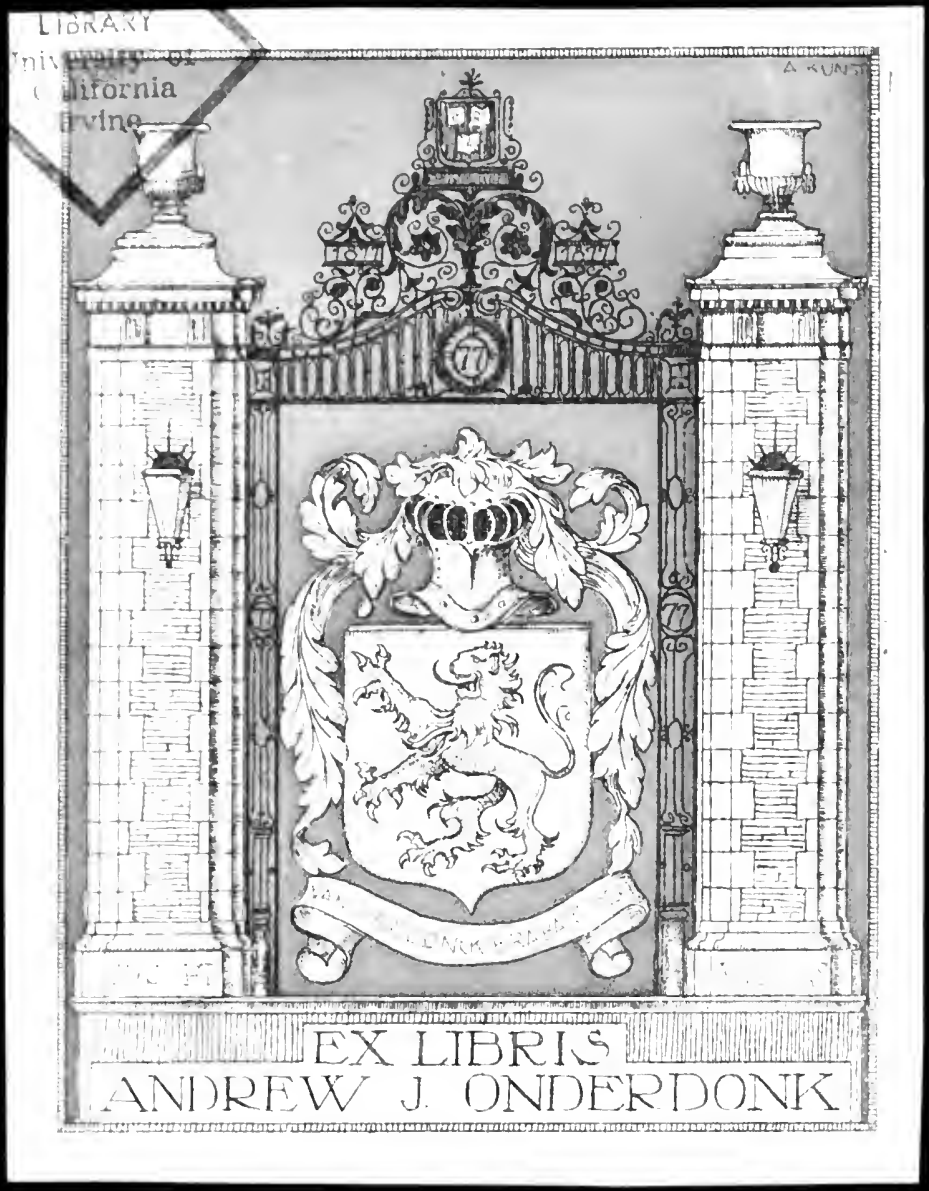


, 



\section{MR. SWINBURNE'S WORKS.}

MR. SWINBURNE'S COLLECTED POEMS. In 6 vols. crown 8vo. 36 s, net. (Sold only in Sets.)

MR. SWINBURNE'S TRAGEDIES. In 5 vols. crown 8vo. 30s. net. (Sold only in Sets.)

SELECTIONS FROM MR. SWINBURNE'S WORKS. Fcp. 8vo. 6 s. THE QUEEN.MOTHER ; and ROSAMOND. Crown 8vo. 7s. 6d. net.

ATALANTA IN CALYDON. Crown 8vo. 6s.

CHASTELARD : a Tragedy. Crown 8vo. 7 s.

POEMS AND BALLADS. First Srries. Crown 8 vo. gs.

POEMS AND BALlads. Second Series. Crown 8vo. gs.

POEMS AND BALLADS. ThiRd SERIEs. Crown 8vo. $7 s$.

SONGS BEFORE SUNRISE. Crown 8vo. xos. $6 d$.

BOTHWELL : a Tragedy. Crown 8vo. 12s. $6 d$.

SONGS OF TWO NATIONS. Crown 8vo. $6 \mathrm{~s}$.

GEORGE CHAPMAN. (In Vol. 11. of G Chapman's Works.) Cr. 8vo. 3s. 6d. ESSAYS AND STUDIES. Crown 8vo. i2s.

ERECHTHEUS : a Tragedy. Crown 8vo. 6s.

A NOTE ON CHARLOTTE BRONT $\ddot{\mathrm{E}}$. Crown 8vo. 6 s.

A STUDY OF SHAKESPEARE. Crown 8 vo. 8 s.

SONGS OF THE SPRINGTIDES. Crown 8 vo. $6 \mathrm{~s}$.

STUDIES IN SONG. Crown 8vo. 7s.

MARY STUART : a Tragedy. Crown 8 vo. 8 s.

TRISTRAM OF LXONESSE, and other Poems. Crown 8vo. 9s.

A CENTURY OF ROUNDELS. Small 4 to. $8 s$.

A MIDSUMMER HOLIDAY, and other Poems. Crown 8vo. 7 s.

MARINO FALIERO : a Tragedy. Crown 8vo. $6 \mathrm{~s}$

A STUDY OF VICTOR HUGO. Crown 8 vo. 6 s.

MISCELLANIES. Crown 8vo. I2s.

LOCRINE : a Tragedy. Crown 8 vo. 6 s.

A STUDY OF BEN JONSON. Crown 8vo. 75.

THE SISTERS : a Tragedy. Crown 8vo. $6 \mathrm{~s}$.

ASTROPHEL, and other Poems. Crown 8vo. 7 s.

STUDIES IN PROSE AND POETRY. Crown 8vo. gr.

THE TALE OF BALEN. Crown 8vo. 7s.

ROSAMUND, Queen of the Lombards : a Tragedy. Crown 8vo. 6s.

A CHANNEL PASSAGE, and other Poems. Crown 8vo. $7 s$.

LOVE'S CROSS-CURRENTS : a Year's Letters. Crown 8vo. 6s. net.

WILLIAM BLAKE. Crown 8vo. 6s. net.

THE DUKE OF GANDIA. Crown 8vo. 5 s.

THE AGE OF SHAKESPEARE. Crown 8vo. 6s. net.

London: CHATTO \& WINDUS, xn St. Martin's Lane, W.C. 
Digitized by the Internet Archive in 2007 with funding from

Microsoft Corporation

http://www.archive.org/details/poemsballadsseco00swiniala 


\section{$P R$ 5506 $\mathrm{PS}^{5}$ \\ 1908}

\section{POEMS AND BALLADS}

SECOND SERIES 
PRINTED BY

SPOTTISWOODE AND CO. LTD., NEW-STREET SQUARE LONDON 


\title{
POEMS AND BALLADS
}

\author{
SECOND SERIES
}

ALGERNON CHARLES SIVINBURNE

A NEW IMPRESSION

\section{LONDON \\ CHATTO \& WINDUS \\ 1908}





\section{IN SCR IBED}

TO

\section{RICHARD F. BURTON}

IN REDEMPTION OF AN OLD PLEDGE AND

IN RECOGNITION OF A FRIENDSHIP WHICH I MUST ALWAYS COUNT

AMONG THE HIGHEST HONOURS OF MY LIFE 



\section{CONTENTS}
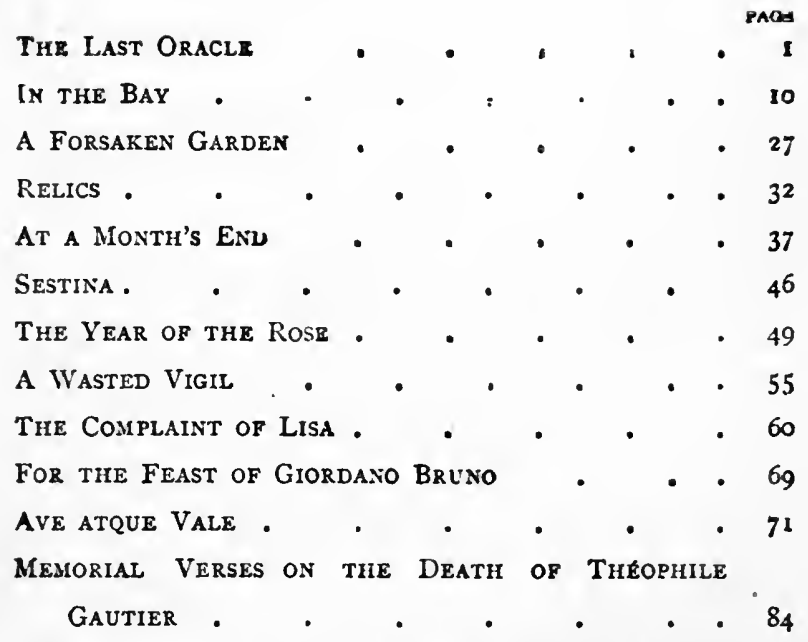

Sonvet (WITH A COPY OF MADEMOISELLE DE

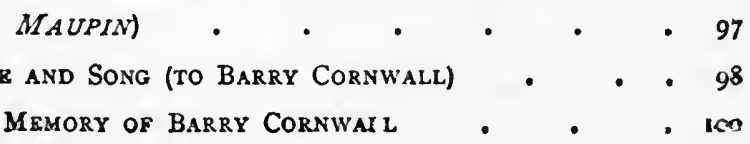


Epicede

TO Victor Hugo . INFERIAR

A Birth-Song Ex.VoTo

a Ballad of Dreamlaid Cyril tourneur

A ballad of françots Villon . Pastiche Before Sunset . SoNg -

A Vision of Spring in Winter. Choriambics . AT Parting

A Song in Season.

Two Leaders

VICTOR HUGO IN 1877 .

ChILD's SONg - . Triads .

Four Songs of Four Selsons:-

I. Winter in NorthumberLaNo

II. Spring in Tuscany

III. Summer in AUvergns

IV. Autumn in Cornwall The IVhite Czar RIZPAH

To Louis Kossuth 
Translations from tHe French of VilloN:-

The Complaint of the fair armouress .

- A Double ballad of Good Counsel .

- 194

Fragment on Death.

- 200

BALLAD OF THE LORDS OF OLd 27ME .

- 204

BALLAD OF THF WOMEN OF PARIS . •

- 206

- 208

BALlad Written for A Bridegroom • • . 210

Ballad against the Enemies of France . . 212

The Dispute of the Heart and Body of Fraxçuis

\section{VILLLON}

- Eistste in form of a Ballad to his Friends

THE EPITAPH IN FORM OF A

From Victor Hugo

Nocturne

ThEophile GautizR

ODE

In Obitum Theophili poete -

ad Catullum .

Dedication, 1878 .
- 215

. 219

- 222

- 225

- 227

- 230

- 232

- 235

- 237

- 239 



\section{THE LAST ORACLE.}

$$
\text { (A.D. 361.) }
$$

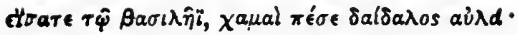

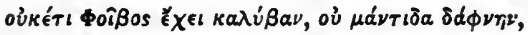

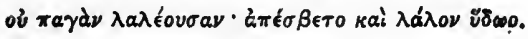

YEARS have risen and fallen in darkness or in twilight, Ages waxed and waned that knew not thee nor thine,

While the world sought light by night and sought not thy light,

Since the sad last pilgrim left thy dark mid shrine.

Dark the shrine and dumb the fount of song thence welling, Save for words more sad than tears of blood, that said:

Tell the king, on earth has fallen the glorious dwelling, And the watersprings that spake are quenched and deas Not a cell is left the God, no roof, no cover;

In his hand the prophet laurel flowers no mure. 
And the great king's high sad heart, thy true last lover,

Felt thine answer pierce and cleave it to the core.

And he bowed down his hopeless lead

In the drift of the wild world's tide,

And dying, Thou hast conquered, he said,

Galilean; he said it, and died.

And the world that was thine and was ours

When the Graces took hands with the Hours

Grew cold as a winter wave

In the wind from a wide-mouthed grave,

As a gulf wide open to swallow

The light that the world held dear.

$O$ father of all of us, Paian, Apollo,

Destroyer and healer, hear!

Age on age thy mouth was mute, thy face was hidden, And the lips and eyes that loved thee blind and dumb; Song forsook their tongues that held thy name forbidden, Light their eyes that saw the strange God's kingdom come. 
Fire for light and hell for heaven and psalms for prans

Filled the clearest eyes and lips most sweet of song,

When for chant of Greeks the wail of Galileans

Made the whole world moan with hymns of wrath and wrong.

Yea, not yet we see thee, father, as they saw thee,

They that worshipped when the world was theirs and thine,

They whose words had power by thine own power to draw thee

Down from heaven till earth seemed more than heaven divine.

For the shades are about us that hover

When darkness is half withdrawn

And the skirts of the dead night cover

The face of the live new dawn.

For the past is not utterly past

Though the word on its lips be the last,

And the time be gone by with its creed

When men were as beasts that bleed, 
As sheep or as swine that wallow,

In the shambles of faith and of fear.

O father of all of us, Paian, Apollo,

Destroyer and healer, hear!

Yet it may be, lord and father, could we know it,

We that love thee for our darkness shall have light

More than ever prophet hailed of old cr poet

Standing crowned and robed and sovereign in thy sight.

To the likeness of one God their dreams enthralled thee,

Who wast greater than all Gods that waned and grew;

Son of God the shining son of Time they called thee,

Who wast older, $O$ our father, than they knew.

For no thought of man made Gods to love or honour

Ere the song within the silent soul began,

Nor might earth in dream or deed take heaven upon her

Till the word was clothed with speech by lips of man.

And the word and the life wast thou,

The spirit of man and the breath;

A:ld before thee the Gods that bow

Take life at thine hands and death. 


\section{THE LAST ORACLE.}

For these are as ghosts that wane,

That are gone in an age or twain ;

Harsh, merciful, passionate, pure,

They perish, but thou shalt endure;

Be their flight with the swan or the swallow,

They pass as the flight of a year.

$O$ father of all of us, Paian, Apollo,

Destroyer and healer, hear !

Thou the word, the light, the life, the breath, the glory,

Strong to help and heal, to lighten and to slay,

Thine is all the song of man, the world's whole story ;

Not of morning and of evening is thy day.

Old and younger Gods are buried or begotten

From uprising to downsetting of thy sun,

Risen from eastward, fallen to westward and forgotten,

And their springs are many, but their end is one.

Divers births of godheads find one death appointed,

As the soul whence each was born makes room for each ; 
God by God goes out, discrowned and disanointed,

But the soul stands fast that gave them shape and speech.

Is the sun yet cast out of heaven?

Is the song yet cast out of man?

Life that had song for its leaven

To quicken the blood that ran

Through the veins of the songless years

More bitter and cold than tears,

Heaven that had thee for its one

Light, life, word, witness, $O$ sun,

Are they soundless and sightless and hollow,

Without eye, without speech, without ear?

$O$ father of all of us, Paian, Apollo,

Destroyer and healer, hear !

Time arose and smote thee silent at his warning,

Change and darkness fell on men that fell from thee;

Dark thou satest, veiled with light, behind the morning, Till the soul of man should lift up eyes and see. 
Tiil the blind mute soul get speech again and eyesight, Man may worship not the light of life within;

In his sight the stars whose fires grow dark in thy sight Shine as sunbeams on the night of death and $\sin$. Time again is risen with mightier word of warning, Change hath blown again a blast of louder breath ;

Clothed with clouds and stars and dreams that melt in morning,

Lo, the Gods that ruled by grace of sin and death !

They are conquered, they break, they are stricken.

Whose might made the whole world pale;

They are dust that shall rise not or quicken

Though the world for their death's sake wail.

As a hound on a wild beast's trace,

So time has their godhead in chase ;

As wolves when the hunt makes head,

They are scattered, they fly, they are fled;

They are fled beyond hail, beyond hollo,

And the cry of the chase, and the cheer.

O father of all of us, Paian, Apollo,

Destroyer and healer, hear 1 
Day by day thy shadow shines in heaven beholden,

Even the sun, the shining shadow of thy face :

King, the ways of heaven before thy feet grow golden;

God, the soul of earth is kindled with thy grace.

In thy lips the speech of man whence Gods were fashioned,

In thy soul the thought that makes them and unmakes;

By thy light and heat incarnate and impassioned,

Soul to soul of man gives light for light and takes.

As they knew thy name of old time could we know it,

Healer called of sickness, slayer invoked of wrong,

Light of eyes that saw thy light, God, king, priest, poet,

Song should bring thee back to heal us with thy song.

For thy kingdom is past not away,

Nor thy power from the place thereof hurled;

Out of heaven they shall cast not the day,

They shall cast not out song from the world.

By the song and the light they give

We know thy works that they live ;

With the gift thou hast given us of speech

We praise, we adore, we beseech, 
We arise at thy bidding and follow,

We cry to thee, answer, appear,

O father of all of us, Paian, Apollo,

Destroyer and healer, hear! 


\section{IN THE BAY.}

I.

BEYond the hollow sunset, ere a star

Take heart in heaven from eastward, while the west

Fulfilled of watery resonance and rest,

Is as a port with clouds for harbour bar

To fold the fleet in of the winds from far

That stir no plume now of the bland sea's breast :

II.

Above the soft sweep of the breathless bay

Southwestward, far past flight of night and day,

Lower than the sunken sunset sinks, and higher

Than dawn can freak the front of heaven with fire,

My thought with eyes and wings made wide makes way

To find the place of souls that I desire. 
III.

If any place for any soul there be,

Disrobed and disentrammelled ; if the might,

The fire and force that filled with ardent light

The souls whose snadow is half the light we see,

Survive and be suppressed not of the night ;

This hour should show what all day hid from ne.

Iv.

Night knows not, neither is it shown to day,

By sunlight nor by starlight is it shown,

Nor to the full moon's eye nor footfall known,

'Their world's untrodden and unkindled way.

Nor is the breath nor music of it blown

$w_{i t h}$ sounds of winter or with winds of May.

v.

But here, where light and darkness reconciled

Hold earth between them as a weanling child 
Between the balanced hands of death and birtn,

Even as they held the new-born shape of earth

When first life trembled in her limbs and smiled,

Here hope might think to find what hope were worth.

VI.

Past Hades, past Elysium, past the long

Slow smooth strong lapse of Lethe-past the tol

Wherein all souls are taken as a spoil,

The Stygian web of waters-if your song

Be quenched not, $\mathrm{O}$ our brethren, but be strone

As ere ye too shook off our temporal coil ;

vir.

If yet these twain survive your worldly breath,

Joy trampling sorrow, life devouring death,

If perfect life possess your life all through

And like your words your souls be deathless too,

To-night, of all whom night encompasseth,

My soul would commune with one soul of you 
viIr.

Above the sunset might I see thine eyes

That were above the sundawn in our skies,

Son of the songs of morning,- - thine that were

First lights to lighten that rekindling air

Wherethrough men saw the front of England rise

And heard thine loudest of the lyre-notes there-

\section{IX.}

If yet thy fire have not one spark the less,

O Titan, born of her a Titaness,

Across the sunrise and the sunset's mark

Send of thy lyre one sound, thy fire one spark,

To change this face of our unworthiness,

Across this hour dividing light from dark.

$\mathbf{x}$.

To change this face of our chill time, that hears

No song like thine of all that crowd its ears, 
Of all its lights that lighten all day long

Sees none like thy most fleet and fiery spnere's Outlightening Sirius-in its twilight throng No thunder and no sunrise like thy song.

XI.

Hath not the sea-wind swept the sea-line bare

To pave with stainless fire through stainless air

A passage for thine heavenlier feet to tread

Ungrieved of earthly floor-work? hath it spread

No covering splendid as the sun-god's hair

To veil or to reveal thy lordlier head?

XII.

Hath not the sunset strewn across the sea

A way majestical enough for thee?

What hour save this should be thine hour-and mine,

If thou have care of any less divine

Than thine own soul; if thou take thought of me,

Marlowe, as all my soul takes thought of thine? 
XIII.

Before the moon's face as before the sun

The morning star and evening star are one

For all men's lands as England. O, if night

Hang hard upon us,--ere our day take flight,

Shed thou some comfort from thy day long done

On us pale children of the latter light !

XIV.

For surely, brother and master and lord and king,

Where'er thy footfall and thy face make spring

In all souls' eyes that meet thee wheresoe'er, And have thy soul for sunshine and sweet airSome late love of thine old live land should cling, Some living love of England, round thee there.

$$
\text { Xv. }
$$

Here from her shore across her sunniest sen My soul makes question of the sun for tnee, 
And waves and beams make answer. When thy feet

Made her ways flowerier and their flowers more sweet

With childlike passage of a god to be,

Like spray these waves cast off her foemen's fleet.

XVI.

like foam they flung it from her, and like weed

Its wrecks were washed from scornful shoal to shoal,

From rock to rock reverberate; and the whole Sea laughed and lightened with a deathless deed That sowed our enemies in her field for seed And made her shores fit harbourage for thy soul.

XVII.

Then in her green south fields, a poor man's child, Thou hadst thy short sweet fill of half-blown joy,

That ripens all of us for time to cloy

With full-blown pain and passion; ere the wild World caught thee by the fiery heart, and smiled To make so swift end of the godlike boy. 
XVIII.

For thou, if ever godlike foot there trod

These fields of ours, wert surely like a god.

Who knows what splendour of strange dreams was shed

With sacred shadow and glimmer of gold and red

From hallowed windows, over stone and sod,

On thine unbowed bright insubmissive head?

xix.

The shadow stayed not, but the splendour stays,

Our brother, till the last of English days.

No day nor night on English earth shall be

For ever, spring nor summer, Junes nor Mays,

But somewhat as a sound or gleam of thee

Shall come on us like morning from the sea.

$\mathbf{x x}$.

Like sunrise never wholly risen, nor yet

Quenched ; or like sunset never wholly set, 
A light to lighten as from living eyes

The cold unlit close lids of one that lies

Dead, or a ray returned from death's far skies

To fire us living lest our lives forget.

XXI.

For in that heaven what light of lights may be.

What splendour of what stars, what spheres of flame

Sounding, that none may number nor may name,

We know not, even thy brethren; yea, not we

Whose eyes desire the light that lightened thee,

Whose ways and thine are one way and the same.

XXII.

But if the riddles that in sleep we read, And trust them not, be flattering truth indeed, As he that rose our mightiest called them,-he, Much higher than thou as thou much higher than weThere, might we say, all flower of all our seed, All singing souls are as one sounding sea. 
XXIII.

All those that here were of thy kind and kin,

Beside thee and below thee, full of love,

Full-souled for song,-and one alone above

Whose only light folds all your glories in-

With all birds' notes from nightingale to dove

Fill the world whither we too fain would win.

Xxiv.

The world that sees in heaven the sovereign light

Of sunlike Shakespeare, and the fiery night

Whose stars were watched of Webster ; and beneath,

The twin-souled brethren of the single wreath,

Grown in king's gardens, plucked from pastoral heath,

Wrought with all flowers for all men's heart's delight.

Xxv.

And that fixed fervour, iron-red like Mars,

In the mid moving tide of tenderer stars, 
That burned on loves and deeds the darkest done, Athwart the incestuous prisoner's bride-house bars; And thine, most highest of all their fires but one, Our morning star, sole risen before the sun.

\section{Xxvi.}

And one light risen since theirs to run such race

Thou hast seen, O Phosphor, from thy pride of place.

Thou hast seen Shelley, him that was to thee As light to fire or dawn to lightning; me, Me likewise, $\mathrm{O}$ our brother, shalt thou see, And I behold thee, face to glorious face?

\section{XXVII.}

You twain the same swift year of manhood swept

Down the steep darkness, and our father wept. And from the gleam of Apollonian tears

A holier aureole rounds your memories, kept Most fervent-fresh of all the singing spheres, And April-coloured through all months and years. 
XXVIII.

You twain fate spared not half your fiery span;

The longer date fulfils the lesser man.

Ye from beyond the dark dividing date

Stand smiling, crowned as gods with foot on fate.

For stronger was your blessing than his ban,

And earliest whom he struck, he struck too late.

XXIX.

Yet love and loathing, faith and unfaith yet

Bind less to greater souls in unison,

And one desire that makes three spirits as one

Takes great and small as in one spiritual net

Woven out of hope toward what shall yet be done

Ere hate or love remember or forget.

xxx.

Woven out of faith and hope and love too great

To bear the bonds of life and death and fate : 
Woven out of love and hope and faith too dear

To take the print of doubt and change and fear :

And interwoven with lines of wrath and hate

Blood-red with soils of many a sanguine year.

\section{XXXI.}

Who cannot hate, can love not; if he grieve,

His tears are barren as the unfruitful rain

That rears no harvest from the green sea's plain,

And as thorns crackling this man's laugh is vain.

Nor can belief touch, kindle, smite, reprieve

His heart who has not heart to disbelieve.

XXXII.

But you, most perfect in your hate and love,

Our great twin-spirited brethren; you that stand

Head by head glittering, hand made fast in hand, And underfoot the fang-drawn worm that strove To wound you living; from so far above, Look love, not scorn, on ours that was your land. 
XXXIII.

For love we lack, and help and heat and light

To clothe us and to comfort us with might.

What help is ours to take or give? but ye-

$O$, more than sunrise to the blind cold sea,

That wailed aloud with all her waves all night,

Much more, being much more glorious, should you be.

XXXIV.

As fire to frost, as ease to toil, as dew

To flowerless fields, as sleep to slackening pain,

As hope to souls long weaned from hope again

Returning, or as blood revived anew

To dry-drawn limbs and every pulseless vein,

Even so toward us should no man be but you.

xxxv,

One rose before the sunrise was, and one

Before the sunset, lovelier than the sun. 
And now the heaven is dark and bright and loud With wind and starry drift and moon and cloud, And night's cry rings in straining sheet and shroud, What help is ours if hope like yours be none?

XXXVI.

O well-beloved, our brethren, if ye be, Then are we not forsaken. This kind earth Made fragrant once for all time with your birth, And bright for all men with your love, and worth The clasp and kiss and wedlock of the sea, Were not your mother if not your brethren we.

\section{XXxvil.}

Because the days were dark with gods and kings And in time's hand the old hours of time as rods, When force and fear set hope and faith at odds, Ye failed not nor abased your plume-plucked wings; And we that front not more disastrous things, How should we fail in face of kings and gods? 
XXXVIII.

For now the deep dense plumes of night are thinned

Surely with winnowing of the glimmering wind

Whose feet are fledged with morning; and the breath

Begins in heaven that sings the dark to death.

And all the night wherein men groaned and sinned

Sickens at heart to hear what sundawn saith.

XXXIX.

$O$ first-born sons of hope and fairest, ye

Whose prows first clove the thought-unsounded sea

Whence all the dark dead centuries rose to bar

The spirit of man lest truth should make him free,

The sunrise and the sunset, seeing one star,

Take heart as we to know you that ye are.

$\mathrm{XL}$,

Ye rise not and ye set not; we that say

Ye rise and set like hopes that set and rise 
Look yet but seaward from a land-locked bay;

But where at last the sea's line is the sky's

And truth and hope one sunlight in your eyes,

No sunrise and no sunset marks their day. 


\section{A FORSAKEN GARDEN.}

IN a coign of the cliff between lowland and highland, At the sea-down's edge between windward and lee, Walled round with rocks as an inland island, The ghost of a garden fronts the sea.

A girdle of brushwood and thorn encloses

The steep square slope of the blossomless bed

Where the weeds that grew green from the graves of its roses

Now lie dead.

The fields fall southward, abrupt and broken,

To the low last edge of the long lone land.

If a step should sound or a word be spoken, Would a ghost not rise at the strange guest's hand? 
So long have the grey bare walks lain guestless,

Through branches and briars if a man make way,

He shall find no life but the sea-wind's, restless

Night and day.

The dense hard passage is blind and stifled

That crawls by a track none turn to climb To the strait waste place that the years have rifled Of all but the thorns that are touched not of time.

'The thorns he spares when the rose is taken;

The rocks are left when he wastes the plain. The wind that wanders, the weeds wind-shaken, These remain.

Not a flower to be pressed of the foot that falls not; As the heart of a dead man the seed-plots are dry;

From the thicket of thorns whence the nightingale calls not,

Could she call, there were never a rose to reply. 


$$
\text { A FORSAKEN GARDEN. }
$$

Over the meadows that blossom and wither

Rings but the note of a sea-bird's song ;

Only the sun and the rain come hither

All year long.

The sun burns sere and the rain dishevels

One gaunt bleak blossom of scentless breath.

Only the wind here hovers and revels

In a round where life seems barren as death.

Here there was laughing of old, there was weeping

Haply, of lovers none ever will know,

Whose eyes went seaward a hundred sleeping

Years ago.

Heart handfast in heart as they stood, 'Look thither,'

Did he whisper? 'look forth from the flowers to the sea ;

For the foam-flowers endure when the rose-blossoms wither,

And men that love lightly may die-but we?' 
And the same wind sang and the same waves whitened,

And or ever the garden's last petals were sl ed,

In the lips that had whispered, the eyes that had lightened, Love was dead.

Or they loved their life through, and then went whither? And were one to the end-but what end who knows? Love deep as the sea as a rose must wither, As the rose-red seaweed that mocks the rose. Shall the dead take thought for the dead to love them? What love was ever as deep as a grave?

They are loveless now as the grass above them Or the wave.

All are at one now, roses and lovers,

Not known of the cliffs and the fields and the sea. Not a breath of the time that has been hovers In the air now soft with a summer to be.

Not a breath shall there sweeten the seasons hereafter Of the flowers or the lovers that laugh now or weep, When as they that are free now of weeping and laughter We shall sleep. 
Here death may deal not again for ever;

Here change may come not till all change end.

From the graves they have made they shall rise up never,

Who have left nought living to ravage and rend.

Earth, stones, and thorns of the wild ground growing,

While the sun and the rain live, these shall be ;

Till a last wind's breath upon all these blowing

Roll the sea.

Till the slow sea rise and the sheer cliff crumble,

Till terrace and meadow the deep gulfs drink,

Till the strength of the waves of the high tides humble

The fields that lessen, the rocks that shrink,

Here now in his triumph where all things falter,

Stretched out on the spoils that his own hand spread,

As a god self-slain on his own strange altar,

Death lies dead. 


\section{RELICS.}

THis flower that smells of honey and the sea, White laurustine, seems in my hand to be A white star made of memory long ago

Lit in the heaven of dear times dead to me

A star out of the skies love used to know Here held in hand, a stray left yet to show What flowers my heart was full of in the days That are long since gone down dead memory's flow.

Dead memory that revives on doubtful ways, Half hearkening what the buried season says

Out of the world of the unapparent dead Where the lost Aprils are, and the lost Mays. 
Flower, once I knew thy star-white brethren bred Nigh where the last of all the land made head Against the sea, a keen-faced promontory, Flowers on salt wind and sprinkled sea-dews fed.

Their hearts were glad of the free place's glory; The wind that sang them all his stormy story Flad talked all winter to the sleepless spray, And as the sea's their hues were hard and hoary.

Like things born of the sea and the bright day, They laughed out at the years that could not slay, Live sons and joyous of unquiet hours, And stronger than all storms that range for prey.

And in the close indomitable flowers

A keen-edged odour of the sun and showers

Was as the smell of the fresh honeycomb Made sweet for mouths of none but paramours. 
Out of the hard green wall of leaves that clomb

They showed like windfalls of the snow-soft foam,

Or feathers from the weary south-wind's wing,

Fair as the spray that it came shoreward from.

And thou, as white, what word hast thou to bring ?

If my heart hearken, whereof wilt thou sing ?

For some sign surely thou too hast to bear,

Some word far south was taught thee of the spring.

White like a white rose, not like these that were

Taught of the wind's mouth and the winter air,

Poor tender thing of soft Italian bloom,

Where once thou grewest, what else for me grew there

Born in what spring and on what city's tomb,

By whose hand wast thou reached, and plucked for whom?

There hangs about thee, could the soul's sense tell,

An odour as of love and of love's doom. 
Of days more sweet than thou wast sweet to smell,

Of flower-soft thoughts that came to flower and fell,

Of loves that lived a lily's life and died,

Of dreams now dwelling where dead roses dwell.

0 white birth of the golden mountain-side

That for the sun's love makes its bosom wide

At sunrise, and with all its woods and flowers

Takes in the morning to its heart of pride 1

Thou hast a word of that one land of ours, And of the fair town called of the Fair Towers,

A word for me of my San Gimignan,

A word of April's greenest-girdled hours.

Of the old breached walls whereon the wallflowers ran

Called of Saint Fina, breachless now of man,

Though time with soft feet break them stone by stone, Who breaks down hour by hour his own reign's span. 
Of tne old cliff overcome and overgrown

That all that flowerage clothed as flesh clothes bone

That garment of acacias made for May,

Whereof here lies one witness overblown.

The fair brave trees with all their flowers at play, How king-like they stood up into the day!

How sweet the day was with them, and the night ! Such words of message have dead flowers to say.

This that the winter and the wind made bright, And this that lived upon Italian light,

Before I throw them and these words away, Who knows but I what memories too take flight? 
AT A MONTH'S END.

THE night last night was strange and shakeu :

More strange the change of you and me.

Once more, for the old love's love forsaken, We went out once more toward the sea.

For the old love's love-sake dead and buried, One last time, one more and no more, We watched the waves set in, the serried Spears of the tide storming the shore.

Hardly we saw the high moon hanging, Heard hardly through the windy night Far waters ringing, low reefs clanging, Under wan skies and waste white light. 
With chafe and change of surges chiming, The clashing channels rocked and rang

Large music, wave to wild wave timing, And all the choral water sang.

Faint lights fell this way, that way floated, Quick sparks of sea-fire keen like eyes From the rolled surf that flashed, and noted Shores and faint cliffs and bays and skies.

The ghost of sea that shrank up sighing At the sand's edge, a short sad breath Trembling to touch the goal, and dying With weak heart heaved up once in death-

The rustling sand and shingle shaken With light sweet touches and small soundThese could not move us, could not waken Hearts to look forth, eyes to look round. 
Silent we went an hour together, Under grey skies by waters white.

Our hearts were full of windy weather, Clouds and blown stars and broken light.

Full of cold clouds and moonbeams drifted And streaming storms and straying fires, Our souls in us were stirred and shifted By doubts and dreams and foiled desires.

Across, aslant, a scudding sea-mew

Swam, dipped, and dropped, and grazed the sea : And one with me I could not dream you ; And one with you I could not be.

As the white wing the white wave's fringes Touched and slid over and flashed pastAs a pale cloud a pale flame tinges From the moon's lowest light and last- 
As a star feels the sun and falters,

Touched to death by diviner eyesAs on the old gods' untended altars

The old fire of withered worship dies-

(Once only, once the shrine relighted

Sees the last fiery shadow shine,

Last shadow of flame and faith benighted,

Sees falter and flutter and fail the shrine)

So once with fiery breath and flying

Your winged heart touched mine and went, And the swift spirits kissed, and sighing,

Sundered and smiled and were content.

That only touch, that feeling only,

Enough we found, we found too much;

For the unlit sbrine is hardly lonely

As one the old fire forgets to touch. 
Slight as the sea's sight of the sea-mew, Slight as the sun's sight of the star : Fnough to show one must not deem you For love's sake other than you are.

Who snares and tames with fear and danger

A bright beast of a fiery kin,

Only to mar, only to change her Sleek supple soul and splendid skin?

Easy with blows to mar and maim her, Easy with bonds to bind and bruise;

What profit, if she yield her tamer The limbs to mar, the soul to lose?

Best leave or take the perfect creature,

Take all she is or leave complete ;

Transmute you will not form or feature, Change feet for wings or wings for feet. 
Strange eyes, new limbs, can no man give her ;

Sweet is the sweet thing as it is.

No soul she hath, we see, to outlive her ;

Hath she for that no lips to kiss?

So may one read his weird, and reason,

And with vain drugs assuage no pain.

For each man in his loving season

Fools and is fooled of these in vain.

Charms that allay not any longing,

Spells that appease not any grief,

Time brings us all by handfuls, wronging

All hurts with nothing of relief.

Ah, too soon shot, the fool's bolt misses I What help? the world is full of loves;

Night after night of running kisses,

Chirp after chirp of changing doves. 


$$
\text { AT A MONTHS END. }
$$

Should Love disown or disesteem you

For loving one man more or less?

You could not tame your light white sea-mew,

Nor I my sleek black pantheress.

For a new soul let whoso please pray,

We are what life made us, and shall be.

For you the jungle and me the sea-spray,

And south for you and north for me.

But this one broken foam-white feather

I throw you off the hither wing,

Splashed stiff with sea-scurf and salt weather,

This song for sleep to learn and sing-

Sing in your ear when, daytime over,

You, couched at long length on hot sand

With some sleek sun-discoloured lover, Wince from his breath as from a brand : 
Till the acrid hour aches out and ceases, And the sheathed eyeball sleepier swims, The deep flank smoothes its dimpling creases, And passion loosens all the limbs :

Till dreams of sharp grey north-sea weather Fall faint upon your fiery sleep, As on strange sands a strayed bird's feather The wind may choose to lose or keep.

But I, who leave my queen of panthers, As a tired honey-heavy bee

Gilt with sweet dust from gold-grained anthers Leaves the rose-chalice, what for me?

From the ardours of the chaliced centre, From the amorous anthers' golden grime, That scorch and smutch all wings that enter, I fly forth hot from honey-time. 


$$
\text { AT A MONTH'S END. }
$$

But as to a bee's gilt thighs and winglets

The flower-dust with the flower-smell clings ;

As a snake's mobile rampant ringlets

Leave the sand marked with print of rings;

So to my soul in surer fashion

Your savage stamp and savour hangs;

The print and perfume of old passion,

The wild-beast mark of panther's fangs. 


\section{SESTINA}

I sAw my soul at rest upon a day

As a bird sleeping in the nest of night,

Among soft leaves that give the starlight way

To touch its wings but not its eyes with lignt;

So that it knew as one in visions may,

And knew not as men waking, of delight.

This was the measure of my soul's delight ;

It had no power of joy to fly by day,

Nor part in the large lordship of the light ;

But in a secret moon-beholden way

Had all its will of dreams and pleasant night, And all the love and life that sleepers may. 
But such life's triumph as men waking may

It might not have to feed its faint delight

Between the stars by night and sun by day,

Shut up with green leaves and a little light ;

Because its way was as a lost star's way,

A world's not wholly known of day or night.

All loves and dreams and sounds and gleams of night

Made it all music that such minstrels may,

And all they had they gave it of delight;

But in the full face of the fire of day

What place shall be for any starry light,

What part of heaven in all the wide sun's way?

Yet the soul woke not, sleeping by the way,

Watched as a nursling of the large-eyed night,

And sought no strength nor knowledge of the day,

Nor closer touch conclusive of delight,

Nor mightier joy nor truer than dreamers may,

Nor more of song than they, nor more of light. 
For who sleeps once and sees the secret light Whereby sleep shows the soul a fairer way

Between the rise and rest of day and night, Shall care no more to fare as all men may, But be his place of pain or of delight, There shall he dwell, beholding night as day.

Sung, have thy day and take thy fill of light Before the night be fallen across thy way; Sing while he may, man hath no long delight. 
THE YEAR OF THE ROSE.

From the depths of the green garden-closes

Where the summer in darkness dozes

Till autumn pluck from his hand

An hour-glass that holds not a sand;

From the maze that a flower-belt encloses

To the stones and sea-grass on the strand

How red was the reign of the roses

Uver the rose-crowned land!

The year of the rose is brief;

From the first blade blown to the sheaf,

From the thin green leaf to the gold,

It has time to be sweet and grow old;

To triumph and leave not a leaf 
For witness in winter's sight

How lovers once in the light

Would mix their breath with its breath,

And its spirit was quenched not of night,

As love is subdued not of death.

In the red-rose land not a mile

Of the meadows from stile to stile,

Of the valleys from stream to stream,

But the air was a long sweet dream

And the earth was a sweet wide smile

Red-mouthed of a goddess, returned

From the sea which had borne her and burned,

That with one swift smile of her mouth

Looked full on the north as it yearned,

And the north was more than the south.

For the north, when winter was long,

In his heart had made him a song, 
And clothed it with wings of desire,

And shod it with shoon as of fire,

To carry the tale of his wrong

To the south-west wind by the sea,

That none might bear it but he

To the ear of the goddess unknown

Who waits till her time shall be

To take the world for a throne.

In the earth beneath, and above

In the heaven where her name is love,

She warms with light from her eyes

The seasons of life as they rise,

And her eyes are as eyes of a dove,

But the wings that lift her and bear

As an eagle's, and all her hair

As fire by the wind's breath curled,

And her passage is song through the air,

And her presence is spring through the world. 
So turned she northward and came, And the white-thorn land was aflame

With the fires that were shed from her feet,

That the north, by her love made sweet,

Should be called by a rose-red name;

And a murmur was heard as of doves,

And a music beginning of loves

In the light that the roses made,

Such light as the music loves,

The music of man with maid.

But the days drop one upon one,

Aud a chill soft wind is begun

In the heart of the rose-red maze

That weeps for the roseleaf days

And the reign of the rose undone

That ruled so long in the light,

And by spirit, and not by sight,

Through the darkness thrilled with its breath, 
Still ruled in the viewless night,

As love might rule over death.

The time of lovers is brief;

From the fair first joy to the grief

That tells when love is grown old,

From the warm wild kiss to the cold,

From the red to the white-rose leaf,

They have but a season to seem

As roseleaves lost on a stream

That part not and pass not apart

As a spirit from dream to dream,

As a sorrow from heart to heart.

From the bloom and the gloom that encloses

The death-bed of Love where he dozes

Till a relic be left not of sand

To the hour-glass that breaks in his hand; 
From the change in the grey garden-closes

To the last stray grass of the strand,

$A$ rain and ruin of roses

Over the red-rose land. 


\section{A WASTED VIGIL}

I.

Couldst thou not watch with me one hour? Behold,

Dawn skims the sea with flying feet of gold,

With sudden feet that graze the gradual sea;

Couldst thou not watch with me?

II.

What not one hour? for star by star the night

Falls, and her thousands world by world take flight ;

They die, and day survives, and what of thee ?

Couldst thou not watch with me?

III.

Lo, far in heaven the web of night undone,

And on the sudden sea the gradual sun; 
Wave to wave answers, tree responds to tree;

Couldst thou not watch with me?

IV.

Sunbeam by sunbeam creeps from line to line,

Foam by foam quickens on the brightening brine;

Sail by sail passes, flower by flower gets free;

Couldst thou not watch with me?

v.

Last year, a brief while since, an age ago,

A whole year past, with bud and bloom and snow,

$\mathrm{O}$ moon that wast in heaven, what friends were we!

Couldst thou not watch with me?

vi.

Old moons, and last year's flowers, and last year's snows!

Who now saith to thee, moon? or who saith, rose ?

$O$ dust and ashes, once found fair to see !

Couldst thou not watch with me ? 


\section{vir.}

O dust and ashes, once thought sweet to smell !

With me it is not, is it with thee well?

O sea-drift blown from windward back to lee!

Couldst thou not watch with me?

vIII.

The old year's dead hands are full of their dead flowers,

The old days are full of dead old loves of ours,

Born as a rose, and briefer born than she;

Couldst thou not watch with me?

IX.

Could two days live again of that dead year,

One would say, seeking us and passing here,

Where is she? and one answering, Where is het

Couldst thou not watch with me? 
$\mathbf{x}$

Nay, those two lovers are not anywhere ;

If we were they, none knows us what we were,

Nor aught of all their barren grief and glee.

Couldst thou not watch with me ?

\section{$\mathbf{x I .}$}

Half false, half fair, all feeble, be my verse

Upon thee not for blessing nor for curse

For some must stand, and some must fall or flee;

Coulust thou not watch with me?

XIr.

As a new moon above spent stars thou wast;

But stars endure after the moon is past.

Couldst thou not watch one hour, though I watch three?

Couldst thou not watch with me? 
XIII.

What of the night? The night is full, the tide

Storms inland, the most ancient rocks divide ;

Yet some endure, and bow nor head nor knee;

Couldst thou not watch with me?

XIV.

Since thou art not as these are, go thy ways;

Thou hast no part in all my nights and days.

Lie still, sleep on, be glad-as such things be ;

Thou couldst not watch with me. 
THE COMPLAINT OF LISA.

(Double Sestina.)

\section{DECAMERON, X. 7 .}

THERE is no woman living that draws breath

So sad as I, though all things sadden her.

There is not one upon life's weariest way

Who is weary as I am weary of all but death.

Toward whom I look as looks the sunflower

All day with all his whole soul toward the sun;

While in the sun's sight I make moan all day,

And all night on my sleepless maiden bed

Weep and call out on death, O Love, and thee,

That thou or he would take me to the dead,

And know not what thing evil I have done

That life should lay such heavy hand on me. 
Alas, Love, what is this thou wouldst with me?

What honour shalt thou have to quench my breath,

Or what shall my heart broken profit thee?

O Love, O great god Love, what have I done,

That thou shouldst hunger so after my death ?

My heart is harmless as my life's first day :

Seek out some false fair woman, and plague her

Till her tears even as my tears fill her bed :

I am the least flower in thy flowery way,

But till my time be come that I be dead

Let me live out my flower-time in the sun

Though my leaves shut before the sunflower.

O Love, Love, Love, the kingly sunflower !

Shall he the sun hath looked on look on me,

That live down here in shade, out of the sun,

Here living in the sorrow and shadow of death?

Shall he that feeds his heart full of the day

Care to give mine eyes light, or my lips breath ?

Because she loves him shall my lord love her 
Who is as a worm in my lord's kingly way?

I shall not see him or know him alive or dead;

But thou, I know thee, O Love, and pray to thee

That in brief while my brief life-days be done,

And the worm quickly make my marriage-bed.

For underground there is no sleepless bed :

But here since I beheld my sunflower

These eyes have slept not, seeing all night and day

His sunlike eyes, and face fronting the sun.

Wherefore if anywhere be any death,

I would fain find and fold him fast to me,

That I may sleep with the world's eldest dead,

With her that died seven centuries since, and her

That went last night down the night-wandering way.

For this is sleep indeed, when labour is done,

Without love, without dreams, and without breath,

And without thought, $O$ name unnamed ! of thee.

Ah, but, forgetting all things, shall I thee?

Wilt thou not be as now about my bed 
There underground as here before the sun?

Siall not thy vision vex me alive and dead,

Thy moving vision without form or breath?

I read long since the bitter tale of her

Who read the tale of Launcelot on a day,

And died, and had no quiet after death,

But was moved ever along a weary way,

Lost with her love in the underworld; ah me,

$\mathrm{O}$ my king, $\mathrm{O}$ my lordly sunflower,

Would God to me too such a thing were done!

But if such sweet and bitter things be done,

Then, flying from life, I shall not fly from thee.

For in that living world without a sun

Thy vision will lay hold upon me dead,

And meet and mock me, and mar my peace in death.

Yet if being wroth God had such pity on her,

Who was a sinner and foolish in her day,

That even in hell they twain should breathe one brexth,

Why should he not in some wise pity me?

So if I sleep not in my soft strait bed 
I may look up and see my sunflower As he the sun, in some divine strange way.

$\mathrm{O}$ poor my heart, well knowest thou in what way

This sore sweet evil unto us was done.

For on a holy and a heavy day

I was arisen out of my still small bed

To see the knights tilt, and one said to me

'The king,' and seeing him, somewhat stopped my breath, And if the girl spake more, I heard not her, For only I saw what I shall see when dead, A kingly flower of knights, a sunflower, That shone against the sunlight like the sun, And like a fire, $\mathrm{O}$ heart, consuming thee, The fire of love that lights the pyre of death

Howbeit I shall not die an evil death Who have loved in such a sad and sinless way, That this my love, lord, was no shame to thee. So when mine eyes are shut against the sun, 
$O$ my soul's sun, $O$ the world's sunflower,

Thou nor no man will quite despise me dead.

And dying I pray with all my low last breath

That thy whole life may be as was that day,

That feast-day that made trothplight death and me,

Giving the world light of thy great deeds done ;

And that fair face brightening thy bridal bed.

That God be good as God hath been to her.

That all things goodly and glad remain with her, All things that make glad life and goodly death;

That as a bee sucks from a sunflower

Honey, when summer draws delighted breath,

Her soul may drink of thy soul in like way,

And love make life a fruitful marriage-bed

Where day may bring forth fruits of joy to day

And night to night till days and nights be dead.

And as she gives light of her love to thee,

Give thou to her the old glory of days long done; 
And either give some heat of light to me,

To warm me where I sleep without the sun.

O sunflower made drunken with the sun,

O knight whose lady's heart draws thine to her,

Great king, glad lover, I have a word to thee.

There is a weed lives out of the sun's way,

Hid from the heat deep in the meadow's bed,

That swoons and whitens at the wind's least breath,

A flower star-shaped, that all a summer day

Will gaze her soul out on the sunflower

For very love till twilight finds her dead.

But the great sunflower heeds not her poor death.

Knows not when all her loving life is done;

And so much knows my lord the king of me.

Aye, all day long he has no eye for me;

With golden eye following the golden sun

From rose-coloured to purple-pillowed bed,

From birthplace to the flame-lit place of death. 
From eastern end to western of his way.

So mine eye follows thee, my sunflower,

So the white star-flower turns and yearns to thee,

The sick weak weed, not well alive or dead,

Trod underfoot if any pass by her,

Pale, without colour of summer or summer breath

In the shrunk shuddering petals, that have done

No work but love, and die before the day.

But thou, to-day, to-morrow, and every day,

$B e$ glad and great, $O$ love whose love slays me.

Thy fervent flower made fruitful from the sun

Shall drop its golden seed in the world's way,

That all men thereof nourished shall praise thee

For grain and flower and fruit of works well done ;

Till thy shed seed, $O$ shining sunflower,

Bring forth such growth of the world's garden-bed

As like the sun shall outlive age and death.

And yet I would thine heart had heed of her 
Who loves thee alive; but not till she be cead.

Come, Love, then, quickly, and take her utmost breath.

Song, speak for me who am dumb as are the dead;

From my sad bed of tears I send forth thee,

To fly all day from sun's birth to sun's death

Down the sun's way after the flying sun,

For love of her that gave thee wings and breath

Ere day be done, to seek the sunflower. 
FOR THE FEAST OF GIORDANO BRUNO, PHILOSOPHER AND MARTYR.

I.

SoN of the lightning and the light that glows

Beyond the lightning's or the morning's light,

Soul splendid with all-righteous love of right,

In whose keen fire all hopes and fears and woes

Were clean consumed, and from their ashes rose

Transfigured, and intolerable to sight

Save of purged eyes whose lids had cast off night,

In love's and wisdom's likeness when they close,

Embracing, and between them truth stands fast,

Embraced of either; thou whose feet were set

On English earth while this was England yet,

Our friend that art, our Sidney's friend that wast,

Heart hardier found and higher than all men's past,

Shall we not praise thee though thine own forget? 
70 FOR THE FEAST OF GIORDANO BRUNO.

II.

Lift up thy light on us and on thine own,

O soul whose spirit on earth was as a rod

To scourge off priests, a sword to pierce their God,

A staff for man's free thought to walk alone,

A lamp to lead him far from shrine and throne

On ways untrodden where his fathers trod

Ere earth's heart withered at a high priest's nod

And all men's mouths that made not prayer made moan.

From bonds and torments and the ravening flame

Surely thy spirit of sense rose up to greet

Lucretius, where such only spirits meet,

And walk with him apart till Shelley came

To make the heaven of heavens more heavenly sweet

And mix with yours a third incorporate name. 


\section{AVE ATQUE VALE. \\ IN MEMORY OF CHARLES BAUDELAIRE.}

Nous Jevrions pourtant lui porter quelques fleurs; Les morts, les paurres morts, ont de grandes douleurs, Et quand Octobre souffle, émondeur des vieux arbres, Son vent mélancolique à l'entour de leurs marbres, Certe, ils doivent trouver les vivants bien ingrate.

Les Fleurs du Mal.

I.

Shall I strew on thee rose or rue or laurel,

Brother, on this that was the veil of thee?

Or quiet sea-flower moulded by the sea,

Or simplest growth of meadow-sweet or. sorrel,

Such as the summer-sleepy Dryads weave,

Waked up by snow-soft sudden rains at eve ?

Or wilt thou rather, as on earth before,

Half-faded fiery blossoms, pale with heat

And full of bitter summer, but more sweet 
To thee than gleanings of a northern shore Trod hy no tropic feet?

II.

For always thee the fervid languid glories

Allured of heavier suns in mightier skies;

Thine ears knew all the wandering watery sighs Where the sea sobs round Lesbian promontories,

The barren kiss of piteous wave to wave

That knows not where is that Leucadian grave

Which hides too deep the supreme head of song.

Áh, salt and sterile as her kisses were,

The wild sea winds her and the green gulfs bear

Hither and thither, and vex and work her wrong,

Blind gods that cannot spare.

III.

Thou sawest, in thine old singing season, brother,

Secrets and sorrows unbeheld of us :

Fierce loves, and lovely leaf-buds poisonous, 
Bare to thy subtler eye, but for none other

Blowing by night in some unbreathed-in clime;

The hidden harvest of luxurious time,

Sin without shape, and pleasure without speech;

And where strange dreams in a tumultuous sleep

Make the shut eyes of stricken spirits weep;

And with each face thou sawest the shadow on each,

Seeing as men sow men reap.

Iv.

$O$ sleepless heart and sombre soul unsleeping,

That were athirst for sleep and no more life

And no more love, for peace and no more strife !

Now the dim gods of death have in their keeping

Spirit and body and all the springs of song,

Is it well now where love can do no wrong,

Where stingless pleasure has no foam or fang

Behind the unopening closure of her lips?

Is it not well where soul from body slips

And flesh from bone divides without a pang

As dew from flower-bell drips? 
v.

It is enough; the end and the beginning

Are one thing to thee, who art past the end.

$O$ hand unclasped of unbeholden friend,

For thee no fruits to pluck, no palms for winning,

No triumph and no labour and no lust,

Only dead yew-leaves and a little dust.

$\mathrm{O}$ quiet eyes wherein the light saith nought,

Whereto the day is dumb, nor any night

With obscure finger silences your sight,

Nor in your speech the sudden soul speaks thought,

Sleep, and have sleep for light.

VI.

Now all strange hours and all strange loves are over,

Dreams and desires and sombre songs and sweet,

Hast thou found place at the great knees and feet

Of some pale Titan-woman like a lover,

Such as thy vision here solicited, 
Under the shadow of her fair vast head,

The deep division of prodigious breasts,

The solemn slope of mighty limbs asleep,

The weight of awful tresses that still keep

The savour and shade of old-world pine-forests

Where the wet hill-winds weep?

\section{vII.}

IIast thou found any likeness for thy vision?

$O$ gardener of strange flowers, what bud, what bloom,

Hast thou found sown, what gathered in the gloom?

What of despair, of rapture, of derision,

What of life is there, what of ill or good?

Are the fruits grey like dust or bright like blood?

Does the dim ground grow any seed of ours,

The faint fields quicken any terrene root,

In low lands where the sun and moon are mute

And all the stars keep silence? Are there flowers

At all, or any fruit? 


\section{VIII.}

Alas, but though my flying song flies after,

$O$ sweet strange elder singer, thy more fleet

Singing, and footprints of thy fleeter feet,

Some dim derision of mysterious laughter

From the blind tongueless warders of the dead,

Some gainless glimpse of Proserpine's veiled head,

Some little sound of unregarded tears

Wept by effaced unprofitable eyes,

And from pale mouths some cadence of dead sighs-

These only, these the hearkening spirit hears,

Sees only such things rise.

IX.

Thou art far too far for wings of words to follow,

Far too far off for thought or any prayer

What ails us with thee, who art wind and air ?

What ails us gazing where all seen is hollow ?

Yet with some fancy, yet with some desire, 
Dreams pursue death as winds a flying fire,

Our dreams pursue our dead and do not find.

Still, and more swift than they, the thin flame flies,

The low light fails us in elusive skies,

Still the foiled earnest ear is deaf, and blind Are still the eluded eyes.

$\mathbf{x}$

Not thee, $O$ never thee, in all time's changes,

Not thee, but this the sound of thy sad soul,

The shadow of thy swift spirit, this shut scroll

I lay my hand on, and not death estranges

My spirit from communion of thy song-

These memories and these melodies that throng

Veiled porches of a Muse funereal-

These I salute, these touch, these clasp and told

As though a hand were in my hand to hold,

Or through mine ears a mourning musical

Of many mourners rolled. 
XI.

I among these, I also, in such station

As when the pyre was charred, and piled the sods,

And offering to the dead made, and their gods,

The old mourners had, standing to make libation,

I stand, and to the gods and to the dead

Do reverence without prayer or praise. and shed

Offering to these unknown, the gods of gloom,

And what of honey and spice my seedlands bear,

And what I may of fruits in this chilled air,

And lay, Orestes-like, across the tomb

A curl of severed hair.

\section{XII.}

But by no hand nor any treason stricken,

Not like the low-lying head of Him, the King,

The flame that made of Troy a ruinous thing,

Thou liest and on this dust nc tears could quicken 
There fall no tears like theirs that all men hear

Fall tear by sweet imperishable tear

Down the opening leaves of holy poets' pages.

Thee not Orestes, not Electra mourns;

But bending us-ward with memorial urns

The most high Muses that fulfil all ages

Weep, and our God's heart yearns.

XII1.

For, sparing of his sacred strength, not often

Among us darkling here the lord of light

Makes manifest his music and his might

In hearts that open and in lips that soften

With the soft flame and heat of songs that shine.

Thy lips indeed he touched with bitter wine,

And nourished them indeed with bitter bread;

Yet surely from his hand thy soul's food came,

The fire that scarred thy spirit at his flame

Was lighted, and thine hungering heart he fed

Who feeds our hearts with fame. 


\section{XIV}

Therefore he too now at thy soul's sunsetting,

God of all suns and songs, he too bends down

To mix his laurel with thy cypress crown.

And save thy dust from blame and from forgetting.

Therefore he too, seeing all thou wert and art,

Compassionate, with sad and sacred heart,

Mourns thee of many his children the last dead,

And hallows with strange tears and alien sighs

Thine unmelodious mouth and sunless eyes,

And over thine irrevocable head

Sheds light from the under skies.

xv.

And one weeps with him in the ways Lethean,

And stains with tears her changing bosom chill :

That obscure Venus of the hollow hill,

That thing transformed which was the Cytherean, 
With lips that lost their Grecian laugh divine

Long since, and face no more called Erycine;

A ghost, a bitter and luxurious god.

Thee also with fair flesh and singing spell

Did she, a sad and second prey, compel

Into the footless places once more trod,

And shadows hot from hell.

xvr.

And now no sacred staff shall break in blossom,

No choral salutation lure to light

A spirit sick with perfume and sweet night

And love's tired eyes and hands and barren bosom.

There is no help for these things; none to mend;

And none to mar; not all our songs, $O$ friend, Will make death clear or make life durable.

Howbeit with rose and ivy and wild vine And with wild notes about this dust of thine At least I fill the place where white dreams dwell And wreathe an unseen shrine. 
XVII.

Sleep ; and if life was bitter to thee, pardon,

If sweet, give thanks; thou hast no more to live ;

And to give thanks is good, and to forgive.

Out of the mystic and the mournful garden

Where all day through thine hands in barren braid

Wove the sick flowers of secrecy and shade,

Green buds of sorrow and sin, and remnants grey,

Sweet-smelling, pale with poison, sanguine-hearted,

Passions that sprang from sleep and thoughts that started,

Shall death not bring us all as thee one day Among the days departed?

XVIII.

For thee, $\mathrm{O}$ now a silent soul, my brother,

Take at my hands this garland, and farewell.

Thin is the leaf, and chill the wintry smell,

And chill the solemn earth, a fatal mother, 


\section{AVE ATQUE VALE.}

With sadder than the Niobean womb,

And in the hollow of her breasts a tomb.

Content thee, howsoe'er, whose days are done ;

There lies not any troublous thing before,

Nor sight nor sound to war against thee more,

For whom all winds are quiet as the sun,

All vaters as the shore. 


\section{MEMORIAL VERSES}

ON THE DEATH OF THÉOPHILE GAUTIER.

DEATH, what hast thou to do with me? So saith

Love, with eyes set against the face of Death;

What have I done, $O$ thou strong Death, to thee,

That mine own lips should wither from thy breath?

Though thou be blind as fire or as the sea,

Why should thy waves and storms make war on me?

Is it for hate thou hast to find me fair,

Or for desire to kiss, if it might be,

My very mouth of song, and kill me there?

So with keen rains vexing his crownless hair,

With bright feet bruised from no delightful way,

Through darkness and the disenchanted air, 
Lost Love went weeping half a winter's day. And the armed wind that smote him seemed to say, How shall the dew live when the dawn is fled, Or wherefore should the Mayflower outlast May ?

Then Death took Love by the right hand and said, Smiling : Come now and look upon thy dead. But Love cast down the glories of his eyes, And bowed down like a flower his flowerless head.

And Death spake, saying : What ails thee in such wise, Being god, to shut thy sight up from the skies ? If thou canst see not, hast thou ears to hear? Or is thy soul too as a leaf that dies?

Even as he spake with fleshless lips of fear, But soft as sleep sings in a tired man's ear, Behold, the winter was not, and its might Fell, and fruits broke forth of the barren year. 
And upon earth was largess of great light, And moving music winged for worldwide flight,

And shapes and sounds of gods beheld and heard And day's foot set upon the neck of night.

And with such song the hollow ways were stirred As of a god's heart hidden in a bird,

Or as the whole soul of the sun in spring Should find full utterance in one flower-soft word,

And all the season should break forth and sing From one flower's lips, in one rose triumphing; Such breath and light of song as of a flame Made ears and spirits of them that heard it ring.

And Love beholding knew not for the same The shape that led him, nor in face nor name, For he was bright and great of thews and fair, And in Love's eyes he was not Death, but Fame. 
Not that grey ghost whose life is empty and bare And his limbs moulded out of mortal air,

A cloud of change that shifts into a shower And dies and leaves no light for time to wear:

But a god clothed with his own joy and power, A god re-risen out of his mortal hour Immortal, king and lord of time and space, With eyes that look on them as from a tower.

And where he stood the pale sepulchral place Bloomed, as new life might in a bloodless face, And where men sorrowing came to seek a tomb With funeral flowers and tears for grief and grace,

They saw with light as of a world in bloom The portal of the House of Fame illume The ways of life wherein we toiling tread, And watched the darkness as a brand consume. 
And through the gates where rule the deathless dead

The sound of a new singer's soul was shed

That sang among his kinsfolk, and a beam

Shot from the star on a new ruler's head.

A new star lighting the Lethean stream,

A new song mixed into the song supreme

Made of all souls of singers and their might,

That makes of life and time and death a dream.

Thy star, thy song, $O$ soul that in our sight

Wast as a sun that made for man's delight

Flowers and all fruits in season, being so near

The sun-god's face, our god that gives us light.

To him of all gods that we love or fear

Thou among all men by thy name wast dear,

Dear to the god that gives us spirit of song

To bind and burn all hearts of men that hear. 
The god that makes men's words too sweet and strong

For life or time or death to do them wrong,

Who sealed with his thy spirit for a sign

And filled it with his breath thy whole life long.

Who made thy moist lips fiery with new wine

Pressed from the grapes of song the sovereign vine,

And with all love of all things loveliest

Gave thy soul power to make them more divine.

That thou might'st breathe upon the breathless rest Of marble, till the brows and lips and breast

Felt fall from off them as a cancelled curse

That speechless sleep wherewith they lived opprest.

Who gave thee strength and heat of spirit to pierce

All clouds of form and colour that disperse,

And leave the spirit of beauty to remould

In types of clean chryselephantine verse. 
Who gave thee words more golden than fine gold

To carve in shapes more glorious than of old,

And build thy songs up in the sight of time As statues set in godhead manifold :

In sight and scorn of temporal change and ciime That meet the sun re-risen with refluent rhyme -As god to god might answer face to faceFrom lips whereon the morning strikes sublime.

Dear to the god, our god who gave thee place Among the chosen of days, the royal race, The lords of light, whose eyes of old and ears Saw even on earth and heard him for a space.

There are the souls of those once mortal years That wrought with fire of joy and light of tears In words divine as deeds that grew thereof Such music as he swoons with love who hears. 
There are the lives that lighten from above

Our under lives, the spheral souls that move

Through the ancient heaven of song-illumined air

Whence we that hear them singing die with love.

There all the crowred Hellenic heads, and there

The old gods who made men godlike as they were,

The lyric lips wherefrom all songs take fire,

live eyes, and light of Apollonian hair.

There, round the sovereign passion of that lyre

Which the stars hear and tremble with desire,

The ninefold light Pierian is made one

That here we see divided, and aspire,

Seeing, after this or that crown to be won;

But where they hear the singing of the sun,

All form, all sound, all colour, and all thought

Are as one body and soul in unison. 
There the song sung shines as a picture wrought,

The painted mouths sing that on earth say nought, The carven limbs have sense of blood and growth And large-eyed life that seeks nor lacks not aught.

There all the music of thy living mouth Lives, and all loves wrought of thine hand in youth And bound about the breasts and brows with gold And coloured pale or dusk from north or south.

Fair living things made to thy will of old, Born of thy lips, no births of mortal mould, That in the world of song about thee wait Where thought and truth are one and manifold.

Within the graven lintels of the gate That here divides our vision and our fate, The direams we walk in and the truths of sleep, All sense and spirit have life inseparate. 
There what one thinks, is his to grasp and keep;

There are no dreams, but very joys to reap,

No foiled desires that die before delight,

No fears to see across our joys and weep.

There hast thou all thy will of thought and sight,

All hope for harvest, and all heaven for flight ;

The sunrise of whose golden-mouthed glad head

To paler songless ghosts was heat and light.

Here where the sunset of our year is red

Men think of thee as of the summer dead,

Gone forth before the snows, before thy day,

With unshod feet, with brows unchapleted.

Couldst thou not wait till age had wound, they say,

Round those wreathed brows his soft white blossoms? Nay,

Why shouldst thou vex thy soul with this harsh air,

Thy bright-winged soul, once free to take its way? 
Nor for men's reverence hadst thou need to wear

The holy flower of grey time-hallowed hair ;

Nor were it fit that aught of thee grew old,

Fair lover all thy days of all things fair.

And hear we not thy words of molten gold

Singing? or is their light and heat acold

Whereat men warmed their spirits? Nay, for all

These yet are with us, ours to hear and hold.

The lovely laughter, the clear tears, the call

Of love to love on ways where shadows fall,

Through doors of dim division and disguise,

And music made of doubts unmusical ;

The love that caught strange light from death's own eyes,! And filled death's lips with fiery words and sighs, And half asleep let feed from veins of his Her close red warm snake's mouth, Egyptian-wise : 
And that great night of love more strange than this, ${ }^{1}$ When she that made the whole world's bale and bliss

Made king of all the world's desire a slave, And killed him in mid kingdom with a kiss;

Veiled loves that shifted shapes and shafts, and gave, ${ }^{2}$

Laughing, strange gifts to hands that durst not crave, Flowers double-blossomed, fruits of scent and hue Sweet as the bride-bed, stranger than the grave ;

All joys and wonders of old lives and new That ever in love's shine or shadow grew, And all the grief whereof he dreams and grieves, And all sweet roots fed on his light and dew;

All these through thee our spirit of sense perceives, As threads in the unseen woof thy music weaves, Birds caught and snared that fill our ears with thee, Bay-blossoms in thy wreath of brow-bound leaves.

- Une Nuit de Cléopatre. 2 Mademoiselle de Maupint. 
Mixed with the masque of death's old comedy

Though thou too pass, have here our flowers, that we For all the flowers thou gav'st upon thee shed, And pass not crownless to Persephone.

Blue lotus-blooms and white and rosy-red We wind with poppies for thy silent head, And on this margin of the sundering sea Leave thy sweet light to rise upon the dead. 


\section{SONNET.}

(WITH A COPY OF MADEMOISELLE DE MAUPIN.)

Tris is the golden book of spirit and sense,

The holy writ of beauty; he that wrought

Made it with dreams and faultless words and thought

That seeks and finds and loses in the dense

Dim air of life that beauty's excellence

Wherewith love makes one hour of life distraught

And all hours after follow and find not aught.

Here is that height of all love's eminence

Where man may breathe but for a breathing-space

And feel his soul burn as an altar-fire

To the unknown God of unachieved desire,

And from the middle mystery of the place

Watch lights that break, hear sounds as of a quire,

But see not twice unveiled the veiled God's face. 
AGE AND SONG.

(TO BARRY CORNWALI.)

I.

IN vain men tell us time can alter

Old loves or make old memories falter,

- That with the old year the old year's life closes.

The old dew still falls on the old sweet flowers,

The old sun revives the new-fledged hours,

The old summer rears the new-born roses.

II.

Much more a Muse that bears upon her

Raiment and wreath and flower of honour,

Gathered long since and long since woven,

Fades not or falls as fall the vernal

Blossoms that bear no fruit eternal,

By summer or winter charred or cloven. 
111.

No time casts down, no time upraises,

Such loves, such memories, and such praises, As need no grace of sun or shower,

No saving screen from frost or thunder

To tend and house around and under The imperishable and fearless flower.

IV.

Old thanks, old thoughts, old aspirations,

Outlive men's lives and lives of nations,

Dead, but for one thing which survives-

The inalienable and unpriced treasure,

The old joy of power, the old pride of pleasure,

That lives in light above men's lives. 


\section{IN MEMORY OF BARRY CORNWALL.}

(OCtober $4,1874$.

I,

IN the garden of death, where the singers whose names are deathless

One with another make music unheard of men,

Where the dead sweet roses fade not of lips long breath. less,

And the fair eyes shine that shall weep not or change again,

Who comes now crowned with the blossom of snow-white years?

What music is this that the world of the dead men hears?

II.

Beloved of men, whose words on our lips were honey, Whose name in our ears and our fathers' ears was sweet, 
Like summer gone forth of the land his songs made sunny, To the beautiful veiled bright world where the glad ghosts meet,

Child, father, bridegroom and bride, and anguish and rest,

No soul shall pass of a singer than this more blest.

III.

Blest for the years' sweet sake that were filled and brightened,

As a forest with birds, with the fruit and the flower of his song;

For the souls' sake blest that heard, and their cares were lightened,

For the hearts' sake blest that have fostered his name so long ;

By the living and dead lips blest that have loved his name, And clothed with their praise and crowned with their love for fance. 
IV.

$\mathrm{Ah}$, fair and fragrant his fame as flowers that close not,

'That shrink not by day for heat or for cold by night,

As a thought in the heart shall increase when the heart's self knows not,

Shall endure in our ears as a sound, in our eyes as a light ;

Shall wax with the years that wane and the seasons' chime, As a white rose thornless that grows in the garden of time.

$$
\text { v. }
$$

The same year calls, and one goes hence with another, And men sit sad that were glad for their sweet songs' sake ;

The same year beckons, and elder with younger brother

Takes mutely the cup from his hand that we all shail take. ${ }^{1}$

They pass ere the leaves be past or the snows be come; And the birds are loud, but the lips that outsang them dumb.

' Sydney Dobell died August 22, 1874. 
IN MEMORY OF BARRY CORNWALL. 103

VI.

rime takes them home that we loved, fair names and famous,

To the soft long sleep, to the broad sweet bosom of death ;

Rut the flower of their souls he shall take not away to slıame us,

Nor the lips lack song for ever that now lack breath.

For with us shall the music and perfume that die not dwell,

Though the dead to our dead bid welcome, and we farewoll. 


\section{EPICEDE.}

(James Lorimer Graham died at Florence, April 30, 1876.)

Life may give for love to death

Little ; what are life's gifts worth

To the dead wrapt round with earth ?

Yet from lips of living breath

Sighs or words we are fain to give,

All that yet, while yet we live,

Life may give for love to death.

Dead so long before his day,

Passed out of the Italian sun

To the dark where all is done,

Fallen upon the verge of May; 
Here at life's and April's end

How should song salute my friend

Dead so long before his day?

Not a kindlier life or sweeter

Time, that lights and quenches men,

Now may quench or light again,

Mingling with the mystic metre

Woven of all men's lives with his

Not a clearer note than this,

Not a kindlier life or sweeter.

In this heavenliest part of earth

He that living loved the light,

Light and song, may rest aright,

One in death, if strange in birth,

With the deathless dead that make

Life the lovelier for their sake

In this heavenliest part of earth. 
Light, and song, and sleep at last-

Struggling hands and suppliant knees

Get no goodlier gift than these.

Song that holds remembrance fast,

Light that lightens death, attend

Round their graves who have to friend

Light, and song, and sleep at last 


\section{TO VICTOR HUGO.}

HE had no children, who for love of men, Being God, endured of Gods such things as thou, Father ; nor on his thunder-beaten brow Fell such a woe as bows thine head again, Twice bowed before, though godlike, in man's ken, And seen too high for any stroke to bow Save this of some strange God's that bends it now The third time with such weight as bruised it then. Fain would grief speak, fain utter for love's sake Some word; but comfort who might bid thee take? What God in your own tongue shall talk with thee, Showing how all souls that look upon the sun Shall be for thee one spirit and thy son, And thy soul's child the soul of man to ke? Fanuary 3, 1876 . 


\section{INFERIAE.}

SPRING, and the light and sound of things on earth Requickening, all within our green sea's girth ;

A time of passage or a time of birth

Fourscore years since as this year, first and last.

The sun is all about the world we see,

The breath and strength of very spring; and we

Live, love, and feed on our own hearts; but he Whose heart fed mine has passed into the past.

Past, all things born with sense and blood and breath;

The flesh hears nought that now the spirit saith.

If death be like as birth and birth as death, The first was fair-more fair should be the last. 
Fourscore years since, and come but one month more

The count were perfect of his mortal score

Whose sail went seaward yesterday from shore

To cross the last of many an unsailed sea.

Light, love and labour up to life's last height,

These three were stars unsetting in his sight;

Even as the sun is life and heat and light

And sets not nor is dark when dark are we.

The life, the spirit, and the work were one

That here-ah, who shall say, that here are done?

Not I, that know not; father, not thy son,

For all the darkness of the night and sea.

March 5, 1877. 


\section{A BIRTH-SONG.}

(For Olivia Frances Madox Rossetti, born September 20, 1875.)

Out of the dark sweet sleep

Where no dreams laugh or weep

Borne through bright gates of birth

Into the dim sweet light

Where day still dreams of night

While heaven takes form on earth.

White rose of spirit and flesh, red lily of love,

What note of song have we

Fit for the birds and thee,

Fair nestling couched beneath the mother-dove?

Nay, in some more divine

Small speechless song of thine 
Some news too good for words,

Heart-hushed and smiling, we

Might hope to have of thee.

The youngest of God's birds,

If thy sweet sense might mix itself with ours.

If ours might understand

The language of thy land,

Ere thine become the tongue of mortal hours:

Ere thy lips learn too soon

Their soft first human tune,

Sweet, but less sweet than now,

And thy raised eyes to read

Glad and good things indeed,

But none so sweet as thou :

Ere thought lift up their flower-soft lids to see

What life and love on earth

Bring thee for gifts at birth,

But none so good as thine who hast given us thee: 
Now, ere thy sense forget

The heaven that fills it yet,

Now, sleeping or awake,

If thou couldst tell, or we

Ask and be heard of thee,

For love's undying sake,

From thy dumb lips divine and bright mute speech

Such news might touch our ear

That then would burn to hear

Too high a message now for man's to reach.

Ere the gold hair of corn

Had withered wast thou born,

To make the good time glad;

The time that but last year

Fell colder than a tear

On hearts and hopes turned sad.

Ifigh hopes and hearts requickening in thy dawn,

Even theirs whose life-springs, child, 


$$
\text { A BIRTH-SONG. }
$$

Filled thine with life and smiled,

But then wept blood for half their own withdrawn.'

If death and birth be one,

And set with rise of sun,

And truth with dreams divine,

Some word might come with thee

From over the still sea

Deep hid in shade or shine,

Crossed by the crossing sails of death and birth,

Word of some sweet new thing

Fit for such lips to bring,

Some word of love, some afterthought of earth.

If love be strong as death,

By what so natural breath

As thine could this be said?

By what so lovely way

Could love send word to say

He lives and is not dead?

1 Oliver Madox Brown died November 5, 1874, in bis twentieth year. 
Such word alone were fit for only thee,

If his and thine have met

Where spirits rise and set,

His whom we see not, thine whom scarce we see,

His there new-born, as thou

New-born among us now ;

His, here so fruitful-souled,

Now veiled and silent here,

Now dumb as thou last year,

A ghost of one year old :

If lights that change their sphere in changing meet,

Some ray might his not give

To thine who wast to live,

And make thy present with his past life sweet?

Let dreams that laugh or weep,

All glad and sad dreams, sleep;

Truth more than dreams is dear. 
Let thoughts that change and fly,

Sweet thoughts and swift, go by ;

More than all thought is here.

More than all hope can forge or memory feign

The life that in our eyes,

Made out of love's life, lies,

And flower-like fed with love for sun and rain.

Twice royal in its root

The sweet small olive-shoot

Here set in sacred earth;

Twice dowered with glorious grace

From either heaven-born race

First blended in its birth;

Fair God or Genius of so fair an hour,

For love of either name

Twice crowned, with love and fame,

Guard and be gracious to the fair-named flower.

Ortober 19, 1875 . 


\section{EX-VOTO.}

WHEN their last hour shall rise

Pale on these mortal eyes,

Herself like one that dies,

And kiss me dying

The cold last kiss, and fold

Close round my limbs her cold

Soft shade as raiment rolled

And leave thern lying,

If aught my soul would say

Might move to hear me pray

The birth-god of my day

That he might hearken,

This grace my heart should crave 
To find no landward grave

That worldly springs make brave,

World's winters darken,

Nor grow through gradual hours

The cold blind seed of flowers

Made by new beams and showere

From limbs that moulder,

Nor take my part with earth,

But find for death's new birth

A bed of larger girth,

More chaste and colder.

Not earth's for spring and fall,

Not earth's at heart, not all

Earth's making, though men call

Earth only mother,

Not hers at heart she bare

Me, but thy child, $O$ fair

Sea, and thy brother's care,

The wind thy brother. 
Yours was I born, and ye,

The sea-wind and the sea,

Made all my soul in me

A song for ever,

A harp to string and smite

For love's sake of the bright:

Wind and the sea's delight,

To fail them never :

Not while on this side death

I hear what either saith

And drink of either's breath

With heart's thanksgiving

That in my veins like wine

Some sharp salt blood of thine:

Some springtide pulse of brine,

Yet leaps up living.

When thy salt lips wellnigh

Sucked in my mouth's last sigh,

Grudged I so much to die 
This death as others?

Was it no ease to think

The chalice from whose brink

Fate gave me death to drink

Was thine-my mother's?

Thee too, the all-fostering earth,

Fair as thy fairest birth,

More than thy worthiest worth,

We call, we know thee,

More sweet and just and dread

'Inan live men highest of head

Or even thy holiest dead

Laid low below thee.

The sunbeam on the sheaf,

'The dewfall on the leaf,

All joy, all grace, all grief,

Are thine for giving ; 
Of thee our loves are born,

Our lives and loves, that mourn

And triumph ; tares with com,

Dead seed with living :

All good and ill things done

In eyeshot of the sun

At last in thee made one

Rest well contented;

All words of all man's breath

And works he doth or saith,

All wholly done to death,

None long lamented.

A slave to sons of thee,

Thou, seeming, yet art free;

But who shall make the sea

Serve even in seeming?

What plough shall bid it bear

Seed to the sun and the air,

Fruit for thy strong sons' fare,

Fresh wine's foam streaming? 
What oldworld son of thine,

Made drunk with death as wine,

Hath drunk the bright sea's brine

With lips of laughter?

Thy blood they drink; but he

Who hath drunken of the sea

Once deeplier than of thee

Shall drink not after.

Of thee thy sons of men

Drink deep, and thirst again ;

For wine in feasts, and then

In fields for slaughter;

But thirst shall touch not him

Who hath felt with sense grown dim

Rise, covering lip and limb,

The wan sea's water.

All fire of thirst that aches

The salt sea cools and slakes

More than all springs or lakes, 
Freshets or shallows ;

Wells where no beam can burn

Through frondage of the fern

That hides from hart and hern

The haunt it hallows.

Peace with all graves on earth

For death or sleep or birth

Be alway, one in worth

One with another;

But when my time shall be,

O mother, O my sea,

Alive or dead, take me,

Me too, my mother. 
A BALLAD OF DREAMLAND.

I HID my heart.in a nest of roses,

Out of the sun's way, hidden apart ;

In a softer bed than the soft white snow's is,

Under the roses I hid my heart.

Why would it sleep not? why should it start,

When never a leaf of the rose-tree stirred?

What made sleep flutter his wings and part?

Only the song of a secret bird.

Lie still, I said, for the wind's wing cioses,

And mild leaves muffle the keen sun's dart;

Iie still, for the wind on the warm sea dozes,

And the wind is unquieter yet than thou art.

Does a thought in thee still as a thorn's wound smart? 
Does the fang still fret thee of hope deferred?

What bids the lids of thy sleep dispart?

Only the song of a secret bird.

The green land's name that a charm enctoses,

It never was writ in the traveller's chart,

And sweet on its trees as the fruit that grows is,

It never was sold in the merchant's mart.

The swallows of dreams through its dim fields dart,

And sleep's are the tunes in its tree-tops heard;

No hound's note wakens the wildwood hart,

Only the song of a secret bird.

\section{ENVOI.}

In the world of dreams I have chosen my part,

To sleep for a season and hear no word

Of true love's truth or of light love's art,

Only the song of a secret bird 


\section{CYRIL TOURNEUR.}

A SEA that heaves with horror of the night, As maddened by the moon that hangs aghast With strain and torment of the ravening blast, Haggard as hell, a bleak blind bloody light ;

No shore but one red reef of rock in sight, Whereon the waifs of many a wreck were cast And shattered in the fierce nights overpast Wherein more souls toward hell than heaven took flight; And 'twixt the shark-toothed rocks and swallowing shoals A cry as out of hell from all these souis

Sent through the sheer gorge of the slaughtering $s \in a_{2}$ Whose thousand throats, full-fed with life by death, Fill the black air with foam and furious breath; And over all these one star-Chastity. 


\section{A BALLAD OF FRANÇOIS VILLON,}

PRINCE OF ALL BALLAD-MAKERS.

BIRD of the bitter bright grey golden morn

Scarce risen upon the dusk of dolorous years,

First of us all and sweetest singer born

Whose far shrill note the world of new men hears

Cleave the cold shuddering shade as twilight clears;

When song new-born put off the old world's attire

And felt its tune on her changed lips expire,

Writ foremost on the roll of them that came Fresh girt for service of the latter lyre, Villon, our sad bad glad mad brother's name ! 
Alas the joy, the sorrow, and the scorn,

That clothed thy life with hopes and sins and fears, And gave thee stones for bread and tares for corn And plume-plucked gaol-birds for thy starveling peers

Till death clipt close their flight with shameful shears; Till shifts came short and loves were hard to hire, When lilt of song nor twitch of twangling wire

Could buy thee bread or kisses; when light fame Spurned like a ball and haled through brake and briar, Villon, our sad bad glad mad brother's name!

Poor splendid wings so frayed and soiled and torn! Poor kind wild eyes so dashed with light quick tears!

Poor perfect voice, most blithe when most forlorn,

That rings athwart the sea whence no man steers

Like joy-bells crossed with death-bells in our ears !

What far delight has cooled the fierce desire

That like some ravenous bird was strong to tire 
On that frail flesh and soul consumed with flame, But left more sweet than roses to respire, Villon, our sad bad glad mad brother's name?

\section{ENVOI.}

Prince of sweet songs made out of tears and fire,

A harlot was thy nurse, a God thy sire;

Shame soiled thy song, and song assoiled thy shame. But from thy feet now death has washed the mire, Love reads out first at head of all our quire, Villon, our sad bad glad mad brother's name. 


\section{FASTICHE.}

Now the days are all gone over

Of our singing, love by lover,

Days of summer-coloured seas

Blown adrift through beam and breeze.

Now the nights are all past over

Of our dreaming, dreams that hover

In a mist of fair false things,

Nights afloat on wide wan wings.

Now the loves with faith for mother

Now the fears with hope for brother,

Scarce are with us as strange words,

Notes from songs of last year's birds. 
Now all good that comes or goes is

As the smell of last year's roses,

As the radiance in our eyes

Shot from summer's ere he dies.

Now the morning faintlier risen

Seems no God come forth of prison,

But a bird of plume-plucked wing,

Pale with thoughts of evening.

Now hath hope, outraced in running,

Given the torch up of his cunning

And the palm he thought to wear

Even to his own strong child-despair. 


\section{BEFORE SUNSET}

IN the lower lands of day On the hither side of night,

There is nothing that will stay, There are all things soft to sight;

Lighted shade and shadowy light

In the wayside and the way,

Hours the sun has spared to smite,

Flowers the rain has left to play.

Shall these hours run down and say

No good thing of thee and me?

Time that made us and will slay

Laughs at love in me and thee; 
But if here the flowers may see

One whole hour of amorous breath, Time shall die, and love shall be Lord as time was over death. 
LOVE laid his sleepless head

On a thorny rosy bed;

And his eyes with tears were red,

And pale his lips as the dead.

And fear and sorrow and scorn

Kept watch by his head forlorn.

Till the night was overworn

And the world was merry with morn.

And Joy came up with the day

And kissed Love's lips as he lay,

And the watchers ghostly and grey

Sped from his pillow away. 
And his eyes as the dawn grew bright,

And his lips waxed ruddy as light:

Sorrow may reign for a night,

But day shall bring back delight. 
A VISION OF SPRING IN WINTER.

I.

O TENDER time that love thinks long to see, Sweet foot of spring that with her footfall sows

Late snowlike flowery leavings of the snows,

Be not too long irresolute to be ;

O mother-month, where have they hidden thee?

Out of the pale time of the flowerless rose

I reach my heart out toward the springtime lands,

I stretch my spirit forth to the fair hours,

The purplest of the prime;

I lean my soul down over them, with hands Made wide to take the ghostly growths of flowers;

I send my love back to the lovely time. 
136. A VISION OF SPRING IN WINTER.

II.

Where has the greeñood hid thy gracious head?

Veiled with what visions while the grey world grieves,

Or muffled with what shadows of green leaves,

What warm intangible green shadows spread

To sweeten the sweet twilight for thy bed ?

What sleep enchants thee? what delight deceives?

Where the deep dreamlike dew before the dawn

Feels not the fingers of the sunlight yet

Its silver web unweave,

Thy footless ghost on some unfonted lawn

Whose air the unrisen sunbeams fear to fret

Lives a ghost's life of daylong dawn and eve.

III.

Sunrise it sees not, neither set of star,

Large nightfall, nor imperial plenilune,

Nor strong sweet shape of the full-breasted noon;

But where the silver-sandalled shadows are, 
Too soft for arrows of the sun to mar,

Moves with the mild gait of an ungrown moon :

Hard overhead the half-lit crescent swims,

The tender-coloured night draws hardly breath,

The light is listening;

They watch the dawn of slender-shapen limbs,

Virginal, born again of doubtful death,

Chill foster-father of the weanling spring.

IV.

As sweet desire of day before the day,

As dreams of love before the true love born,

From the outer edge of winter overworn

The ghost arisen of May before the May

Takes through dim air her unawakened way,

The gracious ghost of morning risen ere morn.

With little unblown breasts and child-eyed looks

Following, the very maid, the girl-child spring,

Lifts windward her bright brows,

Dips her light feet in warm and moving brooks, 
138 A VISION OF SPRING IN WINTER.

And kindles with her own mouth's colouring The fearful firstlings of the plumeless boughs.

v.

I seek thee sleeping, and awhile I see,

Fair face that art not, how thy maiden breatn

Shall put at last the deadly days to death

And fill the fields and fire the woods with thee

And seaward hollows where my feet would be

When heaven shall hear the word that April saith

To change the cold heart of the weary time,

To stir and soften all the time to tears,

Tears joyfuller than mirth ;

As even to May's clear height the young days climb

With feet not swifter than those fair first years

Whose flowers revive not with thy flowers on easth

vi.

I would not bid thee, though I might, give back

One good thing youth has given and borne away;

I crave not any comfort of the day 
That is not, nor on time's retrodden track

Would turn to meet the white-robed hours or black

That long since left me on their mortal way;

Nor light nor love that has been, nor the breath

That comes with morning from the sun to be And sets light hope on fire;

No fruit, no flower thought once too fair for death, No flower nor hour once fallen from life's green tree, No leaf once plucked or once fulfilled desire.

\section{v11.}

The morning song beneath the stars that fled

With twilight through the moonless mountain air,

While youth with burning lips and wreathless hair

Sang toward the sun that was to crown his head,

Rising; the hopes that triumphed and fell dead,

The sweet swift eyes and songs of hours that were;

These may'st thou not give back for ever; these,

As at the sea's heart all her wrecks lie waste, 


\section{A VISION OF SPRING IN WINTER.}

\section{Lie deeper than the sea;}

But flowers thou may'st, and winds, and hours of ease,

And all its April to the world thou may'st

Give back, and half my April back to me. 


\section{CHORIAMBICS.}

LOVE, what ailed thee to leave life that was made lovely, we thought, with love?

What sweet visions of sleep lured thee away, down from the light above?

What strange faces of dreams, voices that called, hands that were raised to wave,

Lured or led thee, alas, out of the sun, down to the sunless grave?

Ah, thy luminous eyes I once was their light fed with the fire of day ;

Now their shadowy lids cover them close, hush them and hide away. 
$\mathrm{Ah}$, thy snow-coloured hands! once were they chains, mighty to bind me fast;

Now no blood in them burns, mindless of love, senseless of passion past.

Ah, thy beautiful hair! so was it once braided for me, for me ;

Now for death is it crowned, only for death, lover and lord of thee.

Sweet, the kisses of death set on thy lips, colder are they than mine;

Colder surely than past kisses that love poured for thy lips as wine.

Lov'st thou death? is his face fairer than love's, brighter to look upon?

Seest thou light in his eyes, light by which love's pales and is overshone? 
Lo the roses of death, grey as the dust, chiller of leaf than snow!

Why let fall from thy hand love's that were thine, roses that loved thee so?

Large red lilies of love, sceptral and tall, lovely for eyes to see;

Thornless blossom of love, full of the sun, fruits that were reared for thee.

Now death's poppies alone circle thy hair, girdle thy breasts as white;

Bloodless blossoms of death, leaves that have sprung never against the light.

Nay then, sleep if thou wilt; love is content; what should he do to weep ?

Sweet was love to thee once; $\mathrm{ncw}$ in thine eyes sweeter than love is sleep. 
AT PARTING.

FOR 3 day and a night Love sang to us, played with us, Folded us round from the dark and the light; And our hearts were fulfilled of the music he made with us, Made with our hearts and our lips while he stayed with us, Stayed in mid passage his pinions from flight For a day and a night.

From his foes that kept watch with his wings had he hidden us,

Covered us close from the eyes that would smite,

From the feet that had tracked and the tongues that had chidden us

Sheltering in shade of the myrtles forbidden us

Spirit and flesh growing one with delight

For a day and a night. 
But his wings will not rest and his feet will not stay for us :

Morning is here in the joy of its might ;

With his breath has he sweetened a night and a day for us $;$

Now let him pass, and the myrtles make way for us ;

Love can but last in us here at his height

For a day and a night. 
A SONG IN SEASON.

I

'THou whose beauty

Knows no duty

Due to love that moves thee never;

Thou whose mercies

Are men's curses,

And thy smile a scourge for ever;

II.

Thou that givest

Death and livest

On the death of thy sweet giving;

Thou that sparest

Not nor carest

Though thy scorn leave no love living; 
III.

Thou whose rootless

Flower is fruitless

As the pride its heart encloses,

But thine eyes are

As May skies are,

And thy words like spoken roses;

IV.

Thou whose grace is

In men's faces

Fierce and wayward as thy will is;

Thou whose peerless

Eyes are tearless,

And thy thoughts as cold sweet lilies;

จ.

Thou that takest

Hearts and makest 
Wrecks of loves to strew behind thee, Whom the swallow Sure should follow, linding summer where we find thee:

$$
\text { vi. }
$$

Thou that wakest

Hearts and breakest, And thy broken hearts forgive thee,

That wilt make no

Pause and take no

Gift that love for love might give thee;

$$
\text { VII. }
$$

Thou that bindest

Eyes and blindest,

Serving worst who served thee longest;

Thou that speakest, And the weakest

Heart is his that was the strongest; 
vili.

Take in season

Thought with reason;

Think what gifts are ours for giving;

Hear what beauty

Owes of duty

To the love that keeps it living.

IX.

Dust that covers

Long dead lovers

Song blows off with breath that brightens;

At its flashes

Their white ashes

Burst in bloom that lives and lightens.

$\mathbf{x}$

Had they bent not

Head or lent not 
Ear to love and amorous duties,

Song had never

Saved for ever,

Love, the least of all their beauties.

$\mathbf{X I}$.

All the golden

Names of olden

Women yet by men's love cherished,

All our dearest

Thoughts hold nearest,

Had they loved not, all had perished

XII.

If no fruit is

Of thy beauties,

Tell me yet, since none may win them,

What and wherefore

Love should care for

Of all good things hidden in them ? 
XIIL.

Pain for profit

Comes but of it,

If the lips that lure their lover's

Hold no treasure

Past the measure

Of the lightest hour that hovers.

\section{XIv.}

If they give not

Or forgive not

Gifts or thefts for grace or guerdon,

Love that misses

Fruit of kisses

Long will bear no thankless burden.

xv.

If they care not

Though love were not, 
If no breath of his burn through them, Joy must borrow Song from sorrow,

Fear teach hope the way to woo them.

$$
\text { XVI. }
$$

Grief has ineasures

Soft as pleasure's,

Fear has moods that hope lies deep in,

Songs to sing him,

Dreams to bring him,

And a red.rose bed to sleep in.

$$
\text { XVII. }
$$

Hope with fearless

Looks and tearless

Lies and laughs too near the thunder;

Fear hath sweeter

Speech and meeter

For heart's love to hide him under. 
XVIII.

Joy by daytime

Fills his playtime

Full of songs loud mirth takes pride in;

Night and morrow

Weave round sorrow

Thoughts as soft as sleep to hide in.

\section{XIX.}

Graceless faces,

Loveless graces,

Are but motes in light that quicken,

Sands that run down

Ere the sundown,

Roseleaves dead ere autumn sicken.

$\mathbf{x x}$.

Fair and fruitless

Charms are bootless 
Spells to ward off age's peril ;

Lips that give not

Love shall live not,

Eyes that meet not eyes are sterile.

$\mathbf{X X I}$.

But the beauty

Bound in duty

Fast to love that falls off never

Love shall cherish

Lest it perish,

And its root bears fruit for ever. 


\section{TWO LEADERS.}

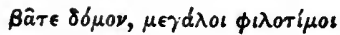

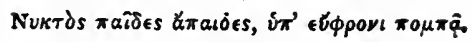

$O$ GREAT and wise, clear-souled and high of heart, One the last flower of Catholic love, that grows Amid bare thorns their only thornless rose,

From the fierce juggling of the priests' loud mart Yet alien, yet unspotted and apart

From the blind hard foul rout whose shameless shows Mock the sweet heaven whose secret no man knows With prayers and curses and the soothsayer's art;

One like a storm-god of the northern foam Strong, wrought of rock that breasts and breaks the sea And thunders back its thunder, rhyme for rhyme Answering, as though to outroar the tides of time 
And bid the world's wave back-what song should be Theirs that with praise would bring and sing you home?

II.

With all our hearts we praise you whom ye hate,

High souls that hate us; for our hopes are higher, And higher than yours the goal of our desire,

Though high your ends be as your hearts are great. Your world of Gods and kings, of shrine and state, Was of the night when hope and fear stood nigher, Wherein men walked by light of stars and fire Till man by day stood equal with his fate.

Honour not hate we give you, love not fear,

Last prophets of past kind, who fill the dome Of great dead Gods with wrath and wail, nor hear Time's word and man's: 'Go honoured hence, go home,

Night's childless children; here your hour is done ; Pass with the stars, and leave us with the sun.' 
VICTOR HUGO IN 1877.

- Dazzle mine eyes, or do I see three suns?

A BOVE the spring-tide sundawn of the year,

A sunlike star, not born of day or night,

Filled the fair heaven of spring with heavenlier light,

Made of all ages orbed in one sole sphere

Whose light was as a Titan's smile or tear ;

Then rose a ray more flowerlike, starry white,

Like a child's eye grown lovelier with delight,

Sweet as a child's heart-lightening laugh to hear ;

And last a fire from heaven, a fiery rain

As of God's wrath on the unclean cities, fell

And lit the shuddering shades of half-seen hell

That shrank before it and were cloven in twain;

A beacon fired by lightning, whence all time

Sees red the bare black ruins of a crime. 
CHILD'S SONG.

WhAT is gold worth, say,

Worth for work or play,

Worth to keep or pay,

Hide or throw away,

Hope about or fear?

What is love worth, pray?

Worth a tear?

Golden on the mould

Lie the dead leaves rolled

Of the wet woods old,

Yellow leaves and cold,

Woods without a dove;

Gold is worth but gold;

Love's worth love. 
TRIADS.

1.

is

THE word of the sun to the sky,

The word of the wind to the sea,

The word of the moon to the night,

What may it be?

II.

The sense to the flower of the fly,

The sense of the bird to the tree,

The sense to the cloud of the light,

Who can tell me?

III.

The song of the fields to the kye,

The song of the lime to the bee,

The song of the depth to the height,

Who knows all three? 


\section{II.}

I.

The message of April to May

That May sends on into June

And June gives out to July

For birthday boon ;

II.

The delight of the dawn in the day,

The delight of the day in the noon,

The delight of a song in a sigh

That breaks the tune;

III.

The secret of passing away,

The cost of the change of the moon,

None knows it with ear or with eye,

But all will soon. 


\section{III.}

I.

The live wave's love for the shore,

The shore's for the wave as it dies,

The love of the thunder-fire

That sears the skies.

I1.

We shall know not though life wax hoar,

Till all life, spent into sighs,

Burn out as consumed with desire

Of death's strange eyes;

ILI.

Till the secret be secret no more

In the light of one hour as it flies,

Be the hour as of suns that expire

Or suns that rise. 

FOUR SONGS OF FOUR SEASONS.

\section{I.}

WINTER IN NORTHUMBERLAND.

I.

OUTSIDE the garden

The wet skies harden;

The gates are barred on

The summer side :

'Shut out the flower-time,

Sunbeam and shower-time;

Make way for our time,'

Wild winds have cried.

Green once and cheery,

The woods, worn weary,

Sigh as the dreary

Weak sun goes home: 
164 FOUR SONGS OF FOUR SEASONS.

A great wind grapples

The wave, and dapples

The dead green floor of the sea with foam.

11.

Through fell and moorland,

And salt-sea foreland,

Our noisy norland

Resounds and rings ;

Waste waves thereunder

Are blown in sunder,

And winds make thunder

With cloudwide wings;

Sea-drift makes dimmer

The beacon's glimmer;

Nor sail nor swimmer

Can try the tides;

And snowdrifts thicken

Where, when leaves quicker,

Under the heather the sundew hides. 
III.

Green land and red land,

Moorside and headland,

Are white as dead land,

Are all as one;

Nor honied heather,

Nor bells to gather,

Fair with fair weatner

And faithful sun :

Fierce frost has eaten

All flowers that sweeten

The fells rain-beaten;

And winds their foes

Have made the snow's bed

Down in the rose-bed;

Deep in the snow's bed bury the rose.

IV.

Bury her deeper

Than any sleeper; 
Sweet dreams will keep her

All day, all night ;

Though sleep benumb her

And time o'ercome her,

She dreams of summer,

And takes delight,

Dreaming and sleeping

In love's good keeping,

While rain is weeping

And no leaves cling;

Winds will come bringing her

Comfort, and singing her

Stories and songs and good news of the spring.

$$
\text { v. }
$$

Draw the white curtain

Close, and be certain

She takes no hurt in

Her soft low bed; 
She feels no colder,

And grows not older,

Though snows enfold her

From foot to head ;

She turns not chilly

Like weed and lily

In marsh or hilly

High watershed,

Or green soft island

In lakes of highland;

She sleeps awhile, and she is not dead.

vi.

For all the hours,

Come sun, come showers,

Are friends of flowers,

And fairies all ;

When frost entrapped her,

They came and lapped her

In leaves, and wrapped her

With shroud and pall; 
In red leaves wound her,

With dead leaves bound her

Dead brows, and round her

A death-knell rang;

Rang the death-bell for her,

Sang, 'is it well for her,

Well, is it well with you, rose?' they sang.

vir.

$O$ what and where is

The rose now, fairies,

So shrill the air is,

So wild the sky?

Poor last of roses,

Her worst of woes is

The noise she knows is

The winter's cry ;

His hunting hollo

Has scared the swallow;

Fain would she follow

And fain would tly : 


\section{But wind unsettles}

Her poor last petals ;

Had she but wings, and she would not die.

viII.

Come, as you love her,

Come close and cover

Her white face over,

And forth again

Ere sunset glances

On foam that dances,

Through lowering lances

Of bright white rain ;

And make your playume

Of winter's daytime,

As if the Maytime

Were here to sing;

As if the snowballs

Were soft like blowballs,

Blown in a mist from the stalk in the sprirg. 
170 FOUR SONGS OF FOUR SEASONS.

IX.

Each reed that grows in

Our stream is frozen,

The fields it flows in

Are hard and black ;

The water-fairy

Waits wise and wary

Till time shall vary

And thaws come back.

'O sister, water,'

The wind besought hel;

- O twin-born daughte

Of spring with me,

Stay with me, play with me,

Take the warm way with me,

Straight for the summer and oversea.

$\mathbf{x}$

But winds will vary,

And wise and wary 
The patient fairy

Of water waits ;

All shrunk and wizen,

In iron prison,

Till spring re-risen

Unbar the gates ;

Till, as with clamour

Of axe and hammer,

Chained streams that stammer

And struggle in straits

Burst bonds that shiver,

And thaws deliver

The roaring river in stormy spates.

XI.

In fierce March weather

White waves break tether,

And whirled together

At either hand, 
Like weeds uplifted,

The tree-trunks rifted

In spars are drifted,

Like foam or sand,

Past swamp and sallow

And reed-beds callow,

Through pool and shallow.

To wind and lee,

Till, no more tongue-tied,

Full flood and young tide

Roar down the rapids and storm the sta.

XII.

As men's cheeks faded

On shores invaded,

When shorewards waded

The lords of fight ;

When churl and craven

Saw hard on haven

The wide-winged raven

At mainmast height ; 
FOUR SONGS OF FOUR SEASONS.

When monks affrighted

To windward sighted

The birds full-flighted

Of swift sea-kings ;

So earth turns paler

When Storm the sailor

Steers in with a roar in the race of his wings

XIII.

O strong sea-sailor,

Whose cheek turns paler

For wind or hail or

For fear of thee?

$O$ far sea-farer.

$\mathrm{O}$ thunder-bearer,

Thy songs are rarer

Than soft songs be.

$O$ fleet-foot stranger,

$O$ north-sea ranger

Through days of danger

And ways of fear. 
174 FOUR SONGS OF FOUR SEASONS.

Blow thy horn here for us,

Blow the sky clear for us,

Send us the song of the sea to hear.

XIV.

Roll the strong stream of it

Up, till the scream of it

Wake from a dream of it

Children that sleep,

Seamen that fare for them

Forth, with a prayer for them ;

Shall not God care for them,

Angels not keep ?

Spare not the surges

Thy stormy scourges;

Spare us the dirges

Of wives that weep.

Turn back the waves for us :

Dig no fresh graves for us,

Wind, in the manifold gulfs of the deep. 
Xv.

O stout north-easter,

Sea-king, land-waster,

For all thine haste, or

Thy stormy skill,

Yet hadst thou never,

For all endeavour,

Strength to dissever

Or strength to spill,

Save of his giving

Who gave our living,

Whose hands are weaving

What ours fulfil ;

Whose feet tread under

The storms and thunder;

Who made our wonder to work his will.

\section{XVI.}

His years and hours,

His world's blind powers, 
146 FOUR SONGS OF FOUR SEASONS.

His stars and flowers,

His nights and days,

Sea-tide and river,

And waves that shiver,

Praise God, the giver

Of tongues to praise.

Winds in their blowing,

And fruits in growing;

Time in its going,

While time shall be;

In death and living,

With one thanksgiving,

Praise him whose hand is the strength of the sea. 
II.

SPRING IN TUSCANY.

ROSE-RED lilies that bloom on the banner;

Rose-cheeked gardens that revel in spring;

Rose-mouthed acacias that laugh as they climb,

Like plumes for a queen's hand fashioned to fan her

With wind more soft than a wild dove's wing,

What do they sing in the spring of their time?

If this be the rose that the world hears singing, Soft in the soft night, loud in the day, Songs for the fire-flies to dance as they hear;

If that be the song of the nightingale, springing

Forth in the form of a rose in May,

What do they say of the way of the year? 
What of the way of the world gone Maying,

What of the work of the buds in the bowers,

What of the will of the wind on the wall,

Fluttering the wall-flowers, sighing and playing,

Shrinking again as a bird that cowers,

Thinking of hours when the flowers have to fall?

Out of the throats of the loud birds showering,

Out of the folds where the flag-lilies leap,

Out of the mouths of the roses stirred,

Out of the herbs on the walls reflowering,

Out of the heights where the sheer snows sleep,

Out of the deep and the steep, one word.

One from the lips of the lily-flames leaping,

The glad red lilies that burn in our sight,

The great live lilies for standard and crown;

One from the steeps where the pines stand sleeping,

One from the deep land, one from the height,

One from the light and the might of the town. 
The lowlands laugh with delight of the highlands, Whence May winds feed them with balm and breatl.

From hills that beheld in the years behind A shape as of one from the blest souls' islands, Made fair by a soul too fair for death, With eyes on the light that should smite them blind.

Vallombrosa remotely remembers,

Perchance, what still to us seems so near

That time not darkens it, change not mars,

The foot that she knew when her leaves were September's,

The face lift up to the star-blind seer,

That saw from his prison arisen his stars.

And Pisa broods on her dead, not mourning,

For love of her loveliness given them in fee ;

And Prato gleams with the glad monk's gift

Whose hand was there as the hand of morning;

And Siena, set in the sand's red sea,

Lifts loftier her head than the red sand's drift. 
And far to the fair south-westward lightens,

Girdled and sandalled and plumed with flowers,

At sunset over the love-lit lands,

The hill-side's crown where the wild hill brightens,

Saint Fina's town of the Beautiful Towers,

Hailing the sun with a hundred hands.

Land of us all that have loved thee dearliest,

Mother of men that were lords of man,

Whose name in the world's heart works as a spell, My last song's light, and the star of mine earliest, As we turn from thee, sweet, who wast ours for a span, Fare well we may not who say farewell. 


\section{III.}

SUMMER IN AUVERGNE.

The sundawn fills the land

Full as a feaster's hand

Fills full with bloom of bland

Bright wine his cup;

Flows full to flood that fills

From the arch of air it thriils

Those rust-red iron hills

With morning up.

Dawn, as a panther springs,

With fierce and fire-fledged wings

Leaps on the land that rings

From her bright feet 
182 FUUR SONGS OF FOUR SEASONS.

Through all its lava-black

Cones that cast answer back

And cliffs of footless track

Where thunders meet.

The light speaks wide and loud

From deeps blown clean of cloud

As though day's heart were proud

And heaven's were glad;

The towers brown-striped and grey

Take fire from heaven of day

As though the prayers they pray

Their answers had.

Higher in these high first hours

Wax all the keen church towers,

And higher all hearts of ours

Than the old hills' crown, 
Higher than the pillared height

Of that strange cliff-side bright

With basalt towers whose might

Strong time bows down.

And the old fierce ruin there

Of the old wild princes' lair

Whose blood in mine hath share

Gapes gaunt and great

Toward heaven that Iong ago

Watched all the wan land's woe

Whereon the wind would blow

Of their bleak hate.

Dead are those deeds; but yet

Their memory seems to fret

Lands that might else forget

That old world's brand; 
184 FOUR SONGS OF FOUR SEASONS.

Dead all their sins and days;

Yet in this red clime's rays

Some fiery memory stays

That scars their land. 
AUTUMN IN CORNWALL.

THE year lies fallen and faded

On cliffs by clouds invaded,

With tongues of storms upbraided.

With wrath of waves bedinned ;

And inland, wild with warning,

As in deaf ears or scorning,

The clarion even and morning

Rings of the south-west wind.

The wild bents wane and wither

In blasts whose breath bows hither

Their grey-grown heads and thither,

Unblest of rain or sun; 
The pale fierce heavens are crowded

With shapes like dreams beclouded, As though the old year enshrouded Lay, long ere life were done.

Full-charged with oldworld wonders, From dusk Tintagel thunders A note that smites and sunders The hard frore fields of air, A trumpet stormier-sounded

Than once from lists rebounded When strong men sense-confounded Fell thick in tourney there.

From scarce a duskier dwelling

Such notes of wail rose welling

Through the outer darkness, telling

In the awful singer's ears 
What souls the darkness covers,

What love-lost souls of lovers,

Whose cry still hangs and hovers

In each man's born that hears.

For there by Hector's brother

And yet some thousand other

He that had grief to mother

Passed pale from Dante's sight;

With one fast linked as fearless,

Perchance, there only tearless;

Iscult and Tristram, peerless

And perfect queen and knight.

A shrill-winged sound comes flying

North, as of wild souls crying

'The cry of things undying,

That know what life must be; 
188 HOUR SONGS OF FOUR SEASONS.

Or as the old year's heart, stricken

Too sore for hope to quicken

By thoughts like thorns that thicken,

Broke, breaking with the sea. 


\section{THE WHITE CZAR.}

[In an English magazine of 1877 there appeared a version of some insolent lines addressed by 'A Russian Poet to the Empress of India.' To these the first of the two following sonnets was designed to serve by way of counterblast. The writer will scarcely be suspected of royalism or imperialism; but it seemed to him that an insult levelled by Muscovite lips at the ruler of England might perhaps be less unfitly than unofficially resented by an Englishman who was also a republican.]

I.

GehazI by the hue that chills thy cheek

And Pilate by the hue that sears thine hand

Whence all earth's waters cannot wash the brand

That signs thy soul a manslayer's though thou speak

All Christ, with lips most murderous and most meek-- 
Thou set thy foot where England's used to stand I

Thou reach thy rod forth over Indian land! Slave of the slaves that call thee lord, and weak As their foul tongues who praise thee! son of them Whose presence put the snows and stars to shame In centuries dead and damned that reek below Curse-consecrated, crowned with crime and flame To them that bare thee like them shalt thou go Forth of man's life-a leper white as snow.

II.

Cail for clear water, wash thine hands, be clean, Cry, What is truth? O Pilate; thou shalt know Haply too soon, and gnash thy teeth for woe Ere the outer darkness take thee round unseen That hides the red ghosts of thy race obscene Bound nine times round with hell's most dolorous flow And in its pools thy crownless head lie low By his of Spain who dared an English queen 
With half a world to hearten him for fight,

Till the wind gave his warriors and their might To shipwreck and the corpse-encumbered sea.

But thou, take heed, ere yet thy lips wax white,

Lest as it was with Philip so it be,

$O$ white of name and red of hand, with thee. 
How many sons, how many generations,

For how long years hast thou bewept, and known

Nor end of torment nor surcease of moan,

Rachel or Rizpah, wofullest of nations,

Crowned with the crowning sign of desolations, And couldst not even scare off with hand or groan Those carrion birds devouring bone by bone The children of thy thousand tribulations?

Thou wast our warrior once; thy sons long dead Against a foe less foul than this made head, Poland, in years that sound and shine afar; Ere the east beheld in thy bright sword-blade's stead The rotten corpse-light of the Russian star That lights towards hell his bondslaves and their Czar. 


\section{3}

\section{TO LOUIS KOSSUTH.}

1877.

Light of our fathers' eyes, and in our own

Star of the unsetting sunset ! for thy name,

That on the front of noon was as a flame

In the great year nigh thirty years agone

When all the heavens of Europe shook and shone

With stormy wind and lightning, keeps its fame

And bears its witness all day through the same;

Not for past days and great deeds past alone,

Kossuth, we praise thee as our Landor praised,

But that now too we know thy voice upraised,

Thy voice, the trumpet of the truth of God,

Thine hand, the thunder-bearer's, raised to smite

As with heaven's lightning for a sword and rod

Men's heads abased before the Muscovite. 
TRANSLATIONS FROM THE FRENCH OF VILLON,

THE COMPLAINT OF THE FAIR ARMOURESS.

I.

Meseemeth I heard cry and groan

That sweet who was the armourer's maid;

For her young years she made sore moan,

And right upon this wise she said;

- Ah fierce old age with foul bald head,

To spoil fair things thou art over fain ;

Who holdeth me? who? would God I were deadI

Would God I were well dead and slain !

Ir.

' Lo, thou hast broken the sweet yoke

That my high beauty held above

All priests and clerks and merchant-folk;

There was not one but for my love 
Would give me gold and gold enough,

Though sorrow his very heart had riven,

To win from me such wage thereof

As now no thief would take if given.

111.

'I was right chary of the same,

God wot it was my great folly,

For love of one sly knave of them,

Good store of that same sweet had he;

For all my subtle wiles, perdie,

God wot I loved him well enow;

Right evilly he handled me,

But he loved well my gold, I trow.

$$
\text { Iv. }
$$

- Though I gat bruises green and black,

I loved him never the less a jot;

Though he bound burdens on my back,

If he said "Kiss me and heed it not" 
Right little pain I felt, God wot,

When that foul thief's mouth, found so sweet,

Kissed me-Much good thereof I got !

I keep the sin and the shame of it.

$$
\text { v. }
$$

'And he died thirty year agonc.

I am old now, no sweet thing to see;

By God, though, when I think thereon, And of that good glad time, woe's me, And stare upon my changed body Stark naked, that has been so sweet, Lean, wizen, like a small dry tree, I am nigh mad with the pain of it.

vi.

'Where is my faultless forehead's white, The lifted eyebrows, soft gold hair, Eyes wide apart and keen of sight, With subtle skill in the amorous air; 
The straight nose, great nor small, but fair,

The small carved ears of shapeliest growth,

Chin dimpling, colour good to wear,

And sweet red splendid kissing mouth ?

VII.

- The shapely slender shoulders small,

Long arms, hands wrought in glorious wise,

Round little breasts, the hips withal

High, full of flesh, not scant of size,

Fit for all amorous masteries ;

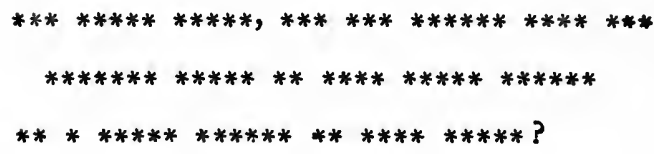

VIII.

'A writhled forehead, hair gone grey,

Fallen eyebrows, eyes gone blind and red,

Their laughs and looks all fled away,

Yea, all that smote men's hearts are fled; 
The bowed nose, fallen from goodlihead;

Foul flapping ears like water-flags;

Peaked chin, and cheeks all waste and dead. And lips that are two skinny rags :

IX.

- Thus endeth all the beauty of us.

The arms made short, the hands made lean,

The shoulders bowed and ruinous,

The breasts, alack! all fallen in;

The flanks too, like the breasts, grown thin;

********************,*******!

For the lank thighs, no thighs but skin, They are specked with spots like sausage-meat.

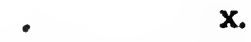

'So we make moan for the old sweet days,

Poor old light women, two or three

Squatting above the straw-fire's blaze,

The bosom crushed against the knee, 


\section{FRENCH OF VILLON.}

Like faggots on a heap we be,

Round fires soon lit, soon quenched and done;

And we were once so sweet, even we !

Thus fareth mi ny and many an one.' 
A DOUBLE BALLAD OF GOOD COUNSEL.

Now take your fill of love and glee,

And after balls and banquets hie ;

In the end ye'll get no good for fee,

But just heads broken by and by ;

Light loves make beasts of men that sigh;

They changed the faith of Solomon,

And left not Samson lights to spy ;

Good luck has he that deals with none!

Sweet Orpheus, lord of minstrelsy,

For this with flute and pipe came nigh

The danger of the dog's heads three

That ravening at hell's door doth lie ; 
Fain was Narcissus, fair and shy,

For love's love lightly lost and won;

In a deep well to drown and die :

Good luck has he that deals with none !

Sardana, flower of chivalry,

Who conquered Crete with horn and cry,

For this was fain a maid to be

And learn with girls the thread to ply;

King David, wise in prophecy,

Forgot the fear of God for one

Seen washing either shapely thigh;

Good luck has he that deals with none !

For this did Amnon, craftily

Feigning to eat of cakes of rye,

Deflower his sister fair to see,

Which was foul incest; and hereby 
Was Herod moved, it is no lie,

'To lop the head of Baptist John

For dance and jig and psaltery ;

Good luck has he that deals with none!

Next of myself I tell, poor me,

How thrashed like clothes at wash was I

Stark naked, I must needs agree ;

Who made me eat so sour a pie

But Katherine of Vaucelles? thereby,

Noé took third part of that fun;

Such wedding-gloves are ill to buy;

Good luck has he that deals with none!

But for that young man fair and free

To pass those young maids lightly by,

Nay, would you burn him quick, not he ;

Like broom-horsed witches though he fry, 
They are sweet as civet in his eye ;

But trust them, and you're fooled anon ;

For white or brown, and low or high,

Good luck has he that deals with none! 


\section{FRAGMENT ON DEATH.}

AND Paris be it or Helen dying,

Who dies soever, dies with pain.

He that lacks breath and wind for sighing,

His gall bursts on his heart; and then

He sweats, God knows what sweat !-again,

No man may ease him of his grief;

Child, brother, sister, none were fain

To bail him thence for his relief.

Death makes him shudder, swoon, wax pale,

Nose bend, veins stretch, and breath surrender,

Neck swell, flesh soften, joints that fail

Crack their strained nerves and arteries slender, 
O woman's body found so tender,

Smooth, sweet, so precious in men's eyes,

Must thou too bear such count to render?

Yes; or pass quick into the skies.

[In the original here follows Villon s masterpiece, the matchless Ballad of the Ladies of Old Time, so incomparably rendered in the marvellous version of D. G. Rossetti ; followed in its turn by the succeeding poem, as inferior to its companion as is my attempt at translation of it to his triumph in that higher and harder feld.A.C. S.] 
BALLAD OF THE LORDS OF OLD TIME.

(AFTER THE FORMER ARGUMENT.)

What more? Where is the third Calixt,

Last of that name now dead and gone,

Who held four years the Papalist?

Alphonso king of Aragon,

The gracious lord, duke of Bourbon,

And Arthur, duke of old Britaine?

And Charles the Seventh, that worthy one?

Even with the good knight Charlemairi.

The Scot too, king of mount and mist,

With half his face vermilion,

Men tell us, like an amethyst

From brow to chin that blazed and shone; 
The Cypriote king of old renown,

Alas! and that good king of Spain,

Whose name I cannot think upon?

Even with the good knight Charlemain.

No more to say of them I list ;

'Tis all but vain, all dead and done :

For death may no man born resist,

Nor make appeal when death comes on.

I make yet one more question;

Where's Lancelot, king of far Bohain ?

Where's he whose grandson called him son?

Even with the good knight Charlemain.

Where is Guesclin, the good Breton?

The lord of the eastern mountain-chain,

And the good late duke of Alençon?

Even with the good knight Charlemain. 
BALLAD OF THE WOMEN OF PARIS.

Albeit the Venice girls get praise

For their sweet speech and tender air,

And though the old women have wise ways

Of chaffering for amorous ware,

Yet at my peril dare I swear,

Search Rome, where God's grace mainly tarries,

Florence and Savoy, everywhere,

There's no good girl's lip out of Paris.

The Naples women, as folk prattle. Are sweetly spoken and subtle enough :

German girls are good at tattle,

And Prussians make their boast thereof; 
Take Fgypt for the next remove,

Or that waste land the Tartar harries,

Spain or Greece, for the matter of love,

There's no good girl's lip out of Paris.

Breton and Swiss know nought of the matter,

Gascony girls or girls of Toulouse ;

Two fishwives here with a half-hour's chatter

Would shut them up by threes and twos;

Calais, Lorraine, and all their crews,

(Names enow the mad song marries)

England and Picardy, search them and choose,

There's no good girl's lip out of Paris.

Prince, give praise to our French ladies

For the sweet sound their speaking carries;

'Twixt Rome and Cadiz many a maid is,

But no good girl's lip out of Paris. 
BALLAD WRITTEN FOR A BRIDEGROOM

WHICH VILLON GAVE TO A GENTLEMAN NEWLY MARRIED TO SEND TO HIS WIFE WHOM HE HAD WON WITH THE SWORD.

AT daybreak, when the falcon claps his wings,

No whit for grief, but noble heart and high,

With loud glad noise he stirs himself and springs,

And takes his meat and toward his lure draws nigh;

Such good I wish you ! Yea, and heartily

I am fired with hope of true love's meed to get;

Know that Love writes it in his book; for why,

This is the end for which we twain are met.

Mine own heart's lady with no gainsayings

You shall be always wholly till I die;

And in my right against all bitter things

Sweet laurel with fresh rose its force shall try; 
Seeing reason wills not that I cast love by

(Nor here with reason shall I chide or fret)

Nor cease to serve, but serve more constantly ;

This is the end for which we twain are met.

And, which is more, when grief about me clings

Through Fortune's fit or fume of jealousy,

Your sweet kind eye beats down her threatenings

As wind doth smoke; such power sits in your eye.

Thus in your field my seed of harvestry

Thrives, for the fruit is like me that I set ;

God bids me tend it with good husbandry;

This is the end for which we twain are met.

Princess, give ear to this my summary ;

That heart of mine your heart's love should forget,

Shall never be : like trust in you put I :

This is the end for which we twain are met. 
BALIAD AGAINST THE ENEMIES OF FRANCE.

MAY he fall in with beasts that scatter fire,

Like Jason, when he sought the fleece of gold,

Or change from man to beast three years entire,

As King Nebuchadnezzar did of old ;

Or else have times as shameful and as bad

As Trojan folk for ravished Helen had;

Or gulfed with Proserpine and Tantalus

Let hell's deep fen devour him dolorous,

With worse to bear than Job's worst sufferance,

Bound in his prison-maze with Dædalus,

Who could wish evil to the state of France !

May he four months, like bitterns in the mire.

Howl with head downmost in the lake-springs cold, 
Or to bear harness like strong bulls for hire

To the Great Turk for money down be sold;

Or thirty years like Magdalen live sad,

With neither wool nor web of linen clad;

Drown like Narciss', or swing down pendulous

Like Absalom with locks luxurious,

Or liker Judas fallen to reprobance ;

Or find such death as Simon sorcerous,

Who could wish evil to the state of France !

May the old times come of fierce Octavian's ire,

And in his belly molten coin be told;

May he like Victor in the mill expire,

Crushed between moving millstones on him rolled,

Or in deep sea drenched breathless, more adrad

Than in the whale's bulk Jonas, when God bade :

From Phœbus' light, from Juno's treasure-house

Driven, and from joys of Venus amorous,

And cursed of God most high to the utterance,

As was the Syrian king Antiochus,

Who could wish evil to the state of France I 
Prince, may the bright-winged brood of Eolus

To sea-king Glaucus' wild wood cavernous

Bear him bereft of peace and hope's least glance,

For worthless is he to get good of us,

Who could wish evil to the state of France $i$ 
THE DISPUTE OF THE HEART AND BODY OF FRANÇOIS VILLON.

Who is this I hear ?-Lo, this is I, thine heart, That holds on merely now by a slender string. Strength fails me, shape and sense are rent apart, The blood in me is turned to a bitter thing, Seeing thee skulk here like a dog shivering. Yea, and for what?-For that thy sense found sweet.What irks it thee?-I feel the sting of it.-

Leave me at peace.-Why?-Nay now, leave me at peace ;

I will repent when I grow ripe in wit.-

I say no more.-I care not though thou cease.- 
What art thou, trow ?-A man worth praise, perfay. -

This is thy thirtieth year of wayfaring.-

'Tis a mule's age.-Art thou a boy still ?-Nay.-

Is it hot lust that spurs thee with its sting,

Grasping thy throat? Know'st thou not anything ?-

Yea, black and white, when milk is specked with fiies,

I can make out_-No more?-Nay, in no wise.

Shall I begin again the count of these?-

Thou art undone.-I will make shift to rise.-

I say no more.-I care not though thou cease.-

I have the sorrow of it, and thou the smart.

Wert thou a poor mad fool or weak of wit,

Then might'st thou plead this pretext with thine heart;

But if thou know not good from evil a whit,

Either thy head is hard as stone to hit,

Or shame, not honour, gives thee most content.

What canst thou answer to this argument ?- 
When I am dead I shall be well at ease.-

God! what good hope!-Thou art over eloquent.-

I say no more.-I care not though thou cease.-

Whence is this ill ?-From sorrow and not from sin. When Saturn packed my wallet up for me

I well believe he put these ills therein.-

Fool, wilt thou make thy servant lord of thee?

Hear now the wise king's counsel; thus saith he:

All power upon the stars a wise man hath;

There is no planet that shall do him scathe.-

Nay, as they made me I grow and I decrease.-

What say'st thou ?-Truly this is all my faith.-

I say no more.-I care not though thou cease.-

Wouldst thou live still ?-God help me that I may !-

Then thou must-What? turn penitent and pray ?-

Read always-What ?-Grave words and good to say; 
Leave off the ways of fools, lest they displease.Good; I will do it.-Wilt thou remember ?-Yea.Abide not till there come an evil day. I say no more.-I care not though thou cease. 
EPISTLB IN FORM OF A BALLAD TO HIS FRIENDS.

Have pity, pity, friends, have pity on me,

Thus much at least, may it please you, of your grace !

I lie not under hazel or hawthorn-tree

Down in this dungeon ditch, mine exile's place

By leave of God and fortune's foul disgrace.

Girls, lovers, glad young folk and newly wed,

Jumpers and jugglers, tumbling heel o'er head,

Swift as a dart, and sharp as needle-ware,

Throats clear as bells that ring the kine to shed,

Your poor old friend, what, will you leave him there?

Singers that sing at pleasure, lawlessly,

Light, laughing, gay of word and deed, that race 
And run like folk light-witted as ye be

And have in hand nor current coin nor base,

Ye wait too long, for now he's dying apace.

Rhymers of lays and roundels sung and read,

Ye'll brew him broth too late when he lies dead.

Nor wind nor lightning, sunbeam nor fresh air,

May pierce the thick wall's bound where lies his bed;

Your poor old friend, what, will you leave him there?

O noble folk from tithes and taxes free,

Come and behold him in this piteous case,

Ye that nor king nor emperor holds in fee,

But only God in heaven; behold his face

Who needs must fast, Sundays and holidays,

Which makes his teeth like rakes; and when he hath fed

With never a cake for banquet but dry bread,

Must drench his bowels with much cold watery fare,

With board nor stool, but low on earth instead;

Your poor old friend, what, will you leave him there? 
Princes afore-named, old and young foresaid,

Get me the king's seal and my pardon sped,

And hoist me in some basket up with care :

So swine will help each other ill bested,

For where one squeaks they run in heaps ahead.

Your poor old friend, what, will you leave him there? 


\section{THE EPITAPH IN FORM OF A BALLAD}

WHICH VILLON MADE FOR HIMSELF AND HIS COMRADES, EXPECTING TO BE HANGED ALONG WITH THEM.

MEN, brother men, that after us yet live,

Let not your hearts too hard against us be ;

For if some pity of us poor men ye give,

The sooner God shall take of you pity.

Here are we five or six strung up, you see,

And here the flesh that all too well we fed

Bit by bit eaten and rotten, rent and shred,

And we the bones grow dust and ash withal;

Let no man laugh at us discomforted,

But pray to God that he forgive us all.

If we call on you, brothers, to forgive,

Ye should not hold our prayer in scorn, though we 
Were slain by law; ye know that all alive Have not wit alway to walk righteously ;

Make therefore intercession heartily

With him that of a virgin's womb was bred,

That his grace be not as a dry well-head

For us, nor let hell's thunder on us fall ;

We are dead, let no man harry or vex us dead,

But pray to God that he forgive us all.

The rain has washed and laundered us all five,

And the sun dried and blackened; yea, perdie,

Ravens and pies with beaks that rend and rive

Have dug our eyes out, and plucked off for fee

Our beards and eyebrows; never are we free,

Not once, to rest ; but here and there still sped,

Drive at its wild will by the wind's change led,

More pecked of birds than fruits on garden-wall;

Men, for God's love, let no gibe here be said,

But pray to God that he forgive us all. 
Prince Jesus, that of all art lord and head,

Keep us, that hell be not our bitter bed ;

We have nought to do in such a master's hall.

Be not ye therefore of our fellowhead,

But pray to God that he forgive us all. 


\section{FROM VICTOR HUGO.}

TAKE heed of this small child of earth;

He is great : he hath in him God most high.

Children before their fleshly birth

Are lights alive in the blue sky.

In our light bitter world of wrong

They come; God gives us them awhile.

His speech is in their stammering tongue,

And his forgiveness in their smile.

Their sweet light rests upon our eyes

Alas! their right to joy is plain.

If they are hungry, Paradise

Weeps, and, if cold, Heaven thrills with pain 
The want that saps their sinless flower Speaks judgment on sin's ministers.

Man holds an angel in his power. Ah! deep in Heaven what thunder stirs,

When God seeks out these tender things

Whom in the shadow where we sleep

He sends us clothed about with wings, And finds them ragged babes that weep! 
NOCTURNE.

LA nuit écoute et se penche sur l'onde

Pour y cueillir rien qu'un souffle d'amour;

Pas de lueur, pas de musique au monde,

Pas de sommeil pour moi ni de séjour.

O mère, ô Nuit, de ta source profonde

Verse-nous, verse enfin l'oubli du jour

Verse l'oubli de l'angoisse et du jour;

Chante; ton chant assoupit l'âme et l'onde :

Fais de ton sein pour mon âme un séjour,

Elle est bien lasse, ô mère, de ce monde,

Où le baiser ne veut pas dire amour,

Où lâme aimée est moins que toi profonde. 
Car toute chose aimée est moins profonde,

O Nuit, que toi, fille et mère du jour;

Toi dont l'attente est le répit du monde,

Toi dont le souffle est plein de mots d'amour,

Toi dont l'haleine enfle et réprime l'onde,

Toi dont l'ombre a tout le ciel pour séjour.

La misère humble et lasse, sans séjour, S'abrite et dort sous ton aile profonde;

Tu fais à tous l'aumône de l'amour :

Toutes les soifs viennent boire à ton onde,

Tout ce qui pleure et se dérobe au jour,

Toutes les faims et tous les maux du monde.

Moi seul je veille et ne vois dans ce monde Que ma douleur qui n'ait point de séjour

Où s'abriter sur ta rive profonde

Et s'endormir sous tes yeux loin du jour ;

Je vais toujours cherchant au bord de l'onde

Le sang du beau pied blessé de l'amour. 
La mer est sombre où tu naquis, amour,

Pleine des pleurs et des sanglots du monde;

On ne voit plus le gouffre où naît le jour

Luire et frémir sous ta lueur profonde;

Mais dans les cœurs d'homme où tu fais séjour

La douleur monte et baisse comme une onde.

ENVOI.

Fille de l'onde et mère de l'amour,

Du haut séjour plein de ta paix profonde

Sur ce bas monde épands un peu de jour. 


\section{THÉOPHILE GAUTIER.}

Pour mettre une couronne au front d'une chanson,

Il semblait qu'en passant son pied semât des roses,

Et que sa main cueillit comme des fleurs écioses

Les étoiles au fond du ciel en floraison.

Sa parole de marbre et d'or avait le son

Des clairons de l'été chassant les jours moroses;

Comme en Thrace Apollon banni des grands cieux roses,

Il regardait du cœur l'Olympe, sa maison.

Le soleil fut pour lui le soleil du vieux monde,

Et son œil recherchait dans les flots embrasés

Le sillon immortel d'où s'élança sur l'onde 


\section{THEOPHILE GAUTIER.}

Vérus, que la mer molle enivrait de baisers :

Enfin, dieu ressaisi de sa splendeur première,

Il trône, et son sépulcre est bâti de lumière. 
$O D E$.

(LE TOMBEAU DE THEOPHILE GAUTHER,)

Quelle fleur, ô Mort, quel joyau, quel chant, Quel vent, quel rayon de soleil couchant,

Sur ton front penché, sur ta main avide, Sur l'âpre pâleur de ta ievre aride,

Vibre encore et luit?

Ton sein est sans lait, ton oreille est vide, Ton œil plein de nuit.

'Ta bouche est sans souffle et ton front sans ride;

Mais l'éclair voilé d'une flamme humide,

Flamme éclose au cœur d'un ciel fluvieux,

Rallume ta lèvre et remplit tes yeux

De lueurs d'opale ;

$\mathrm{Ta}$ bouche est vermeille et ton front joyeux,

$\mathrm{O}$ toi qui fus pâle. 
Comme aux jours divins la mère des dieux,

Reine au sein fécond, au corps radieux,

Tu surgis au bord de la tombe amère ;

Tu nous apparais, ô Mort, vierge et mère,

Effroi des humains,

Ie divin laurier sur la tête altière

Et la lyre aux mains.

Nous reconnaỉssons, courbés vers la terre,

Que c'est la splendeur de ta face austère

Qui dore la nuit de nos longs malheurs;

Que la vie ailée aux mille couleurs,

Dont tu n'es que l'âme,

Refait par tes mains les prés et les fleurs,

La rose et la femme.

Lune constante! astre ami des douleurs

Qui luis à travers la brume des pleurs !

Quelle famme au fond de ta clarte molle 
Eclate et rougit, nouvelle auréole,

Ton doux front voilé?

Quelle étoile, ouvrant ses ailes, s'envole Du ciel étoilé ?

Pleurant ce rayon de jour qu'on lui vole,

L'homme exècre en vain la Mort triste et folle;

Mais l'astre qui fut à nos yeux si beau,

Là-haut, loin d'ici, dans un ciel nouveau

Plein d'autres étoiles,

Se lève, et pour lui la nuit du tombeau

Entr'ouvre ses voiles.

L'âme est dans le corps comme un jeune oiseau

Dont l'aile s'agite au bord du berceau ;

La mort, déliant cette aile inquiète,

Quand nous écoutons la bouche muette

Qui nous dit adieu,

Fait de l'homme infime et sombre un poëte,

Du poëte un dieu. 
IN OBITUM THEOPHILI POETA.

O Lux Pieridum et laurigeri deliciæ dei,

Vox leni Zephyro lenior, ut veris amans novi

Tollit floridulis implicitum primitiis caput, Ten' ergo abripuit non rediturum, ut redeunt novo Flores vere novi, te quoque mors irrevocabilem? Cur vatem neque te Musa parens, te neque Gratıæ, Nec servare sibi te potuit fidum animi Venus? Quæ nunc ipsa magis vel puero te Cinyreïo, $\mathrm{Te}$ desiderium et flebilibus lumen amoribus, Amissum queritur, sanguineis fusa comam genis. Tantis tu lacrymis digne, comes dulcis Apollini, Carum nomen eris dis superis atque sodalibus Nobis, quîs eadem quæ tibi vivo patuit via Non æquis patet, at te sequimur passibus haud tuis, 
=36 IN OBITUM THEOPHILI POETE.

At mæsto cinerem carmine non illacrymabilem

Tristesque exuvias floribus ac fletibus integris

Unà contegimus, nec citharâ nec sine tibiâ,

Votoque unanimæ vocis Ave dicimus et Vale. 


\section{AD CATULLUM.}

Catulle frater, ut velim comes tibi

Remota per vireta, per cavum nemus

Sacrumque Ditis haud inhospiti specus,

Pedem referre, trans aquam Stygis ducem

Secutus unum et unicum, Catulle, te,

$\mathrm{Ut}$ ora vatis optimi reviserem,

Tui meique vatis ora, quem scio

Venustiorem adîsse vel tuo lacum,

Benigniora semper arva vel tuis,

Ubi serenus accipit suos deus,

Tegitque myrtus implicata laureâ,

Manuque mulcet halituque consecrat

Fovetque blanda mors amabili sinu,

Et ore fama fervido colit viros 
Alitque qualis unus ille par tibi

Britannus unicusque in orbe præstitıt

Amicus ille noster, ille ceteris

Poeta major, omnibusque floribus

Priore Landor inclytum rosâ caput

Revinxit extulitque, quam tuâ manu

Recepit ac refovit integram suâ. 


\section{DEDICATION}

$$
1878 \text {. }
$$

SOME nine years gone, as we dwelt together

In the sweet hushed heat of the south French weather

Ere autumn fell on the vine-tressed hills

Or the season had shed one rose-red feather,

Friend, whose fame is a flame that fills

All eyes it lightens and hearts it thrills

With joy to be born of the blood which bred

From a land that the grey sea girds and chills

The heart and spirit and hand and head

Whose might is as light on a dark day shed,

On a day now dark as a land's decline

Where all the peers of your praise are dead, 
In a land and season of corn and vine

I pledged you a health from a beaker of mine

But halfway filled to the lip's edge yet

With hope for honey and song for wine.

Nine years have risen and eight years set

Since there by the wellspring our hands on it met :

And the pledge of my songs that were then to be,

I could wonder not, friend, though a friend should forget.

For life's lielm rocks to the windward and lee,

And time is as wind, and as waves are we;

And song is as foam that the sea-winds fret,

Though the thought at its heart should be deep as the sea. 


\section{CHATTO \& WINDUS'S POPULAR TWO-SHILLING NOVELS BY THE BEST AUTHORS.}

\section{BOUND IN PICTURB CLOTH, FLAT BACKS.}

BY EDWII LESTER ARNOLD, The Constable of St. Nio oias, BY SIR WALTER BESANT, St. Katherine's by the Tower. The Rebel Queen. BY HAROLD BINDLOSS. Anslie's Ju-ju.

BY McD. BODKIM K.C.

Dore Myrl. Lady Detective. BY DICK DONOYAN,

The Man-hunter.

Tales of Terror.

Vincent Trtll, Detectlve.

Dark Deeds. J Wanted I

The Man from Manchestir.

Mystery of Jamalca Terrace.

BY GEORGE MAHVILLE FEMK.

$\triangle$ Orimson Orime.

BY PAUL BAULOT,

The Red Slirts.

BY MANOR A 6RIFFITHS.

No. 99 ; \&nd Blue Blood. BY BRET HARTE.

Lnck of Roaring Oamp; and Sensat1 on NovelsCondensad. In $\mathrm{H}$ Hollow of the Hills.

A Sappho of Green Springs. Colorel Starbottle' Ollent.

A Protégé of Jack Hamlin's. Bally Dows.

BY MRS, ALEXAKOER,

Mald, Wife, or Widow?

Valerie'a Fate.

Blind Fato.

$\Delta$ Life Interest.

Mons'e Oholce.

BJ Woman's Wit.

\section{BY GRAKT ALLEN,}

Btrange Storiea

Philistia.

Babylon.

The Beckoning Hand.

In All Shrdes.

For Mraimie's Sake.

The Derll's Die.

This Mortal Coil.

The Tents of Shem.

The Great Tsboo.

Damsresq's Daughter.

The Dnohess of Porysland.

Blood-Royal.

Iran Greet's Mastorpiece.

The Scallywag.

At Market Valne.

Under Sealed Ordera.

BY EOWIN LESTER ARNOLD.

Purs the Phoenician.

BY OWEN HALL.

The Track of a Storm.

BY HEADOH HILL.

Zsmbrs, the Detective.

BY FERBUS VUNE,

The Lady from Nowhera.

BY EDMUND MITCHELL.

Plotters of Paris.

The Temple of Desth.

Towards the Eternal Snows.

BY BERTRAM MITFORD.

The Luck of Gerard Ridgoley.

The King's Assegsi.

BY J, E, MUDOOCK.

Maid Marian \& Robin Hood.

BY D, CHRISTIE MURRAY.

His Own Ghost.

Syrlin.

BY OUIDA.

The Waters of Eders.

BY JAMES PAYA.

A Modern Diok Whittington.

BY DORA RUSSELL,

A Oountry Sweetheart.

The Drift of Fate.

BOUND IN PICTURE BOARDS.

BY FRAIKK BARRETT.

A Recoiling Vengeance.

For Love and Honour.

John Ford; \& His Helpmate.

Honest Davie.

$\Delta$ Prodigal's Progress.

Folly Morrison.

Lieutenant Barnabas.

Found Guilty.

Fettered for Life.

Between Life and Death.

The Sin of Olga Zassoulloh.

Little Lady Linton.

Woman of the Irou Broelets.

The Harding Scindal.

$A$ Missing Witness

BY BESART AHD RICE,

Ready-Money Mortiboy.

With Harp and Crown.

This Son of Vulcan.

My Little Girl.

The Case of Mr. Lnoraft.

The Golden Buttertly.

By Celis's Arbour.

The Monks of Thelems.

"Twas in Trafalgar's Bay.

The Seamy Side.

The Ten Years' Tenant.

The Ohaplain of the Fleet.
Br B. R. SIMS.

In Iondon's Heart.

Rogues and Vagrbonds.

BY FRAKK STOCKTOK.

The Young Master of Hyou Hall.

BI SUNDOWMER.

The Tale of the Serpent.

BY SARAK TYTLER,

Oitosenne Jacquelline.

BY ALLEN UPWARD,

The Queen against $O$ wen.

BY FLOREMGE WARDEN,

Joan, the Curate.

BY BYROK WEBBER,

Sport and Spangles.

BY JOHN STRANGE WIRTER.

Oavalry Llfe; and Regimen!s' Legends.

BY LOUIS 2ANGWILL.

A NineteenthCentary Miracle.

\section{BY WALTER BESAHT.} All Sorts \& Conditions of Men. The Csptains' Room.

All in a Garden Falr.

Dorothy Forster.

Unole Jack.

Ohildren of Gibeon.

World went very well then.

Herr Panlas.

For Faith and Freedom.

To Call her Mine.

The Bell of St. Paul's

The Holy Rose.

Armorel of Lyonessa.

St. Katherine's by the Tower.

The Irory Gate.

Verbens Camellia Stephanotis

The Robel Queen.

Beyoud the Dreams ofd varice.

The Rerolt of Man.

In Deacon's Orders.

Tho Master Craftsman.

The Oity of Refuge.

BY AMBROSE BIERCE,

In the didst of Life

BY FREDERICK BOYLE,

Camp Notes. Iarage Life. Chronicles of No-Man's Land.

London: CHATTU \& WINDCS, 111 St. Martin's Lane, W.C. 
BY ROBERT BUCHAKAY. The Sluadow of the Sword. A Child of Nature. God and the Man. A nnan Water.

The New Abelard.

The Martyrdom of Madeline. Iove Me for Kver.

Matt: a Story of a Caravan. Foxglove Manor.

The Master of the Mine.

The Heir of Linne.

Woman and the Man.

Rachel Dene.

Lajy Eilpatrick.

\section{BY BUCHAKAN \& MURRAY.}

The Charlatan.

BY HALL CAINE.

The Shadow of a Orime.

A Son of Hagar.

The Deemster.

BY COMMAYDER GAMERON.

Cruise of the 'Black Prince.'

BY AUSTIN CLARE.

For the Love of a Lass.

BY MRS. ARCHER CLIVE.

Paul Ferroll.

Way Paul Ferroll Killed Wife.

BY MACLAREN COBBAN.

The Cure of Sonls.

The ked Sultan.

\section{BY YILXIE COLLINS.}

Armadale. | After Dark.

A Rogue's Life.

Hide snd Seek.

The Dead Secret.

No Name | Antonina

Basil. Queen of Hearts.

My Miscellanies.

The Woman in White.

The Moonstone.

Man and Wife.

Poor Miss Finch.

Miss or Mrs.?

The New Magdalen.

The Frozen Deep.

The Law and the Iady.

The Two Destinies.

The Haunted Hotel.

The Fallen Leaves.

Jezebel'a Daughter.

The Black Robe.

Heart and Science.

'I say No." | Blind Lore.

The Evil Genius.

Llttle Novels.

The Legacy of Cain.

BY M. J. COLQUHOU..

Every Inch a Soldier.

EY G. EGBERT CRADDOCK.

The Prophet of the Great Smoky Monntains.
BY MORTIMER AND F, GOLLIKS, Sweet Anne Page.

Transmigration.

From Midnight to Midnight.

A Fight with Fortune.

Sweet and Twenty.

Frances.

The Village Comedy.

Yon Play Me False.

Blacksmith and Scholar.

BY MATT GRIM,

Adventures of a Fair Rebel.

BY B, M. CROKER.

Pretty Miss Neville.

Proper Pride. | 'To Let."

A Bird of Passage.

Diana Barrington.

A Family Likeness.

Village Tales and Jungle

Tragedies.

Two Masters. | Mr. Tervis.

The Real Lady Hilda.

Married or Single?

Interference. | A Third Person

BY ALPHONSE OAUDET.

The Evangelist.

BY JAMES DE MILLE,

A Strange Mannscript found In a Oopper Cylinder.

BY DICK DONOYAK,

The Man-hunter.

Caught at Last!

Trucked and Taken.

Who Poisoned Hetty Duncan ?

The Man from Manchester.

A Detective's Trinmphs.

In the Grip of the Law.

Wanted! | Link by Link.

From Information Recelved,

Tracked to Doom.

Suspioion Aroused.

Riddles Read.

Mystery of Jamaica Terrace.

The Ohronicles of Miohsel

Danevitch.

BY MRS, ANMIE EOWARDES.

A Point of Honour.

Archie Lovell. Roxy.

BY EDHARD EGGLESTOH.

BY 6. MANVILLE FENH.

The New Mistress.

Witness to the Deed

The Tiger Lily.

The White Virgin.

BY PERCY FITZGERALO.

Bella Donna I Polly.

The Second Mrs. Tillotson.

Seventy-five Brooke Street.

Never Forgotten.

The Lady of Brantome.

Fatal Zero.

BY PERCY FITZGERALD, \&C. Strange Secrets.
BY R, E, FRANCILLON.

Olympla. I One by Ove.

Queen Cophetua.

A Real Queen.

King or Knave.

Romances of the Law.

Ropes of Sand.

$A$ Dog and his Shadow.

BY HAROLD FREDERIG.

Seth's Brother's Wife.

The Lawton Girl.

PREFACED BY BARTLE FRERE,

Pandurang Harl.

BY CHARLES GIBBON.

Robin Gray.

For Lack of Gold.

What will the World Say?

In Honour Bound.

In Love and War.

For the King. I Fancy Free.

Queen of the Meadow.

In Pastures Green.

The Flower of the Forest.

A Heart'a Problem.

The Braes of Yarrow.

The Golden Shaft.

Of High Degree.

The Dead Heart.

By Mead and Stream.

Heart's Delight.

Loving a Dream.

A Hard Knot. / Blood-Money,

BY WILLIAM GILBERT.

James Duke, Costermonger.

BY ERNEST GLANVILLE.

The Lost Heiress,

The Fossicker.

$\triangle$ Fair Colonist.

BY REV, S, BARING GOULD,

Eve. | Red Splder.

BY ANOREW HALLIDAY.

Every-Day Papers.

BY THOMAS HARDY,

Onder the Greenwood Tree.

BY BRET HARTE.

An Heiress of Red Dog.

The Luck of Roaring Camp

Californian Stories.

Gabriel Conroy.

Flip.

A Phyllis of the Sierras.

A Waif of the Plains.

A Ward of the Golden Gate.

BY JULIAK HAWTHORNE.

Garth. Ellice Quentin.

Dust. Fortane's Fool.

Beatrix Randolph.

Miss Cadogna.

Love-or a Name.

David Poindexter's Disappearance.

The spectre of the Oamera.

London: CHATTO \& WINDUS, 111 St. Martin's Lane, W.C. 


\section{BY SIR ARTHUR HELPS,}

Iran de Blron.

BY 6. A. HENTY:

Rujub, the Juggler.

BY HEADON HILL.

Zambra, the Detective.

BY JOHN HILL,

Treason-Felony.

BY MRS, CASHEL HOEY,

The Lover's Creed.

BY MRS, HUNGERFORD,

In Durance Vile.

A Mraiden sll Forlorn.

A Mental Struggle.

Marvel

A Modern Circe.

Lady Terner's Flight.

The Red-Honse Mysterg.

The Three Graces.

An Unsatigfactory Lover.

Lady Patty.

Nora Oreina.

The Prolessor's Experiment.

A pril's Lady.

Peter's Wife.

BY MRS, ALFRED HUNT,

The Leaden Casket.

Eelt-Condemned.

That Other Person.

\section{BY MARK KERSHAW.}

Colonial Facts and Fictions.

BY R, ASHE KING,

$\triangle$ Drawn Game.

-The Wearing of the Green.

Passion's Slave.

Bell Barry.

BY EDMOND LEPELLETIER.

Yadame Sans-Gêne.

The Lindsays.

BY JOHY LEYS.

BY E. LYNH LIMTON.

Patricia Kemball.

Atonement of Leam Dundas.

Tue World Well Last.

Cnder whlch Iord ?

With a Silken Thread.

The Rebel of the Family.

'Míy Iovel"

Ione.

Paston Carew.

Soring the Wind.

The One Too Many.

Dulcie Everton.

BY HEHRY W. LUCY.

Gideon Flejce.

\section{BY JUSTIK MCCARTHY.}

Dear Lady Díbdain.

The Waterdale Nelghboura.

My Enemy's Dsughter.

A Fair Saxon.

Linley Rochford.

Miss Misanthrope.

Douna Quixote.

The Comet of a Season.

Maid of Athens.

Camlola: Girl with a Fortane.

The Dictator.

Red Diamonds.

The Riddle Ring.

BY HUGH MacCOLL.

IIr. Stranger's Sealed Paoket.

BY GEORGE MACDONALD.

Heatber and Snow.

BY MRS, MACDONELL

Quaker Consins

BY H. H. MALLOCX.

The New Repablic.

BY J. MASTERMAN,

Hall-a-Dozeu Donshters.

BY BRANOER MATTHEWS.

A Secret of the Sea.

BY L. T, MEADE.

$\triangle$ Soldier of Fortune.

\section{BY LEONARD MERRICK.}

The Man who was Grood.

BY MRS, MOLESWORTH.

Hathercourt Rectory.

BY J, E, NUDDOCK.

Stories Weird and Wonderful. The Dead Man's Secret.

From the Bosom of the Deep.

BY D, CHRISTIE MURRAY.

A Life's Atonement.

Joseph's Cost.

Val Strange.

A Y Yodel Fsther.

Coals of Fire.

Heart8.

By the Gste of the Sea.

The Way of the World.

A Bit of Human Nature.

First Person Singular.

Cynic Fortune.

Old Blazer's Hero.

Bob Martin's Little Girl.

Time's Revenges

A Wasted Crime.

In Direst Peril.

Monnt Despair.

A Ospfnl o' Nails.

BY D. GHRISTIE MURRAY AND HENRY HERMAN.

One Traveller Returng

Paul Jones's Alias.

The Bishops' Blble.
BY HUME NISBET.

'Bail Up?'

Dr. Bernard St. Vincent.

BY W. E, NORRIS.

Salnt Ann's. | Billy Bellew.

BY GEORGES OHNET.

Doctor Rameal.

A Iast Love I A Weird Gift. BY MRS, OLIPHANT,

Whiteladies.

The Primrose Path.

Greatest Heiress in England. BY OUIDA.

Held in Bondage.

Strathmore.

Chandos.

Under Two Flags.

Idalia

Cecil Castlemaine's Gaga.

Tricotrin.

Puck.

Folle Farine

A Dog of Flanders.

Pascarèl.

Slgna

In a Winter Oity.

Ariadne.

Moths.

Friendship.

Plpistrello.

Bimbi.

In Maremma

Wanda.

Frescoes.

Princess Nspraxine.

Two Iittle Wooden Shoes.

A Village Commane.

Othmar.

Guilderos.

Rnflino.

Syrlin.

Santa Barbara.

Two Offenders.

Wisdom, Wit, and Psthos.

BY MARGARET AGNES PAUL.

Gentle anỏ Simple. BY JANES PAYR.

Lost Sir Massingberd.

A Perfect Treasure.

Bentinck's Tutor.

Murphy's Master.

A County Family.

At Her Mercy.

A Woman's Vengeance.

Cecil's Tryst.

The Clyffards of Clyffe.

The Family Scspegrace

The Foster Brothers.

The Best of Husbands.

Found Dead.

Walter's Word. | Halves.

Falleu Fortnnes.

What He Cost Her.

Hamorous Stories.

Grendoline's Harvest.

Like Father, Like son.

London: CHATTO \& WINDUS, 111 St. Martin's Lane, W.C. 
JAMES PAYK-continued.

A Martne Residenoe.

Married Beneath Hifm.

Mirk $\triangle$ bbey.

Not Wooed, but Won.

\&200 Reward.

Les Bleck than we're Palnted

By Proxy.

Higb Spirits.

Cnder One Root.

Oarlyon's Year.

A Confldential Agent.

Bome Private Views.

A Grape from a Thorn.

From Exile.

Kit : a Memory.

For Cash Only.

The Canon's Ward.

The Taik of the Town.

Hollday Tasks.

Glow-worm Tales.

The Mystery of Mirbridge

The Burnt Million.

The Word and the Will.

A Prinoe of the Blood.

Bunny Storien.

A Trying Patient.

BY MRS, CAMPBELL PRAED,

The Romance of a Station.

The Soul of Countegs Adrian.

Outlaw and Lawmaker.

Christins Chard.

Mrs. Tregaskiss.

BY RICHARD PRYCE,

Mis Marwell's Affections,

BY CHARLES READE,

It is Never Too Late to Jíend.

Hard Cash.

Peg Woffington.

Ohristie Johnstone.

Griffith Gaunt.

Pat Yourself in His Place.

The Double Marriage.

Love Me Little, LoveMe Long.

Foul Play.

The Oloister and the Hearth.

The Course of True Love.

The Autobiography of a Thief.

A Terrible Temptation.

The Wandering Heir.

A Simpleton.

A Woman-Hater.

Singleheart and Doubleface.

Good Stories of Man and other Animals.

The Jilt.

A. Perilous Secret.

Beadiana.

BY MRS, d, H, RIDDELL,

Her Mother's Darling.

The Uninhabited House.

Welrd Stories.

Falry Water.

Prince Wales's Garden Party. Mysuery in Palace Gardens.

Idite Tales.
BY F, W. ROBINSOH,

Women are Strange.

The Hands of Justice.

The Woman In the Dark.

BY DORA RUSSELL,

$\triangle$ Country Sweetheart.

BY W, CLARK RUSSELL,

Round the Galley Fire. On the Fo'k'sle Head.

In the Middle Watch

$\triangle$ Voyage to the Cape.

$\Delta$ Book for the Hammock.

Mystery of the 'Ocean Star.'

Romance of Jenny Harlowe.

An Ocean Tragedy.

My Shipmate Louise.

Alone on a Wide Wide Sea.

The Phantom Death.

The Good Ship 'Mrobook.'

Is he the Uan? I Heart of Oaz.

The Convict Ship.

The Tale of the Ten.

The Last Entry.

BY ALAH ST, AJBYH,

A Fellow of Trinity.

The Junlor Dean.

The Master of St. Benedict's.

To his Own Master.

Orchard Damerel.

In the Face of the World.

The Tremlett Diamonds.

BY GEORGE AUEUSTUS SALA. Gaslight and Daylight.

BY GEOREE R, SIMS,

The Ring o' Bells.

Mary Jane's Memoirs.

Mary Jane Harried.

Tales of To-day.

Dramas of Iife.

Tinkletop's Orime.

Zeph : a Oircus Story.

My Two Wives.

Memolns of a Landlady.

Scenes from the Suow.

The Ten Commandments.

Dagonet Abroad.

Rogues and Yagabonds.

BY T, $W$, SPEIEHT.

The Ifysteries of Heron Dyke.

The Golden Hoop.

By Devious Wass.

Hood winked. I Back to Life.

The Lond water 'l'ragedy.

Burgo's Romance.

Quittance in Full.

A Husband from the Sea.

BY R, A, STERMDALE,

The Afghan Knife.
BY R. LOUIS STEYERSOL.

New Arabian Nighte.

BY WALTER THORNBURY.

Tales for the Marines.

BY AMTHOAY TROLLOPE.

The Way We Live Now.

Mr. Scarborough's Family.

The Golden Lion of Graupdre

The American Senstor.

Frau Frohmann.

Marion Fay.

Kept in the Dark.

The Land-Leaguere.

BY FRANCES E, TROLLOPE, Anne Furnese.

jlabel's Progress.

Like Ships upon the Sea

BY T, ADOLPHUS TROLLCPE

Diamond Cut Diamond.

\section{BY MARX TWAIK,}

Tom Sawyer.

The Stolen White Elephant.

Pleasure Trip on Continent

The Gilded Age.

Hinkleberry Finn.

Life on the Misslssippi.

Mark Twain's Sketches.

The $£ 1,000,000$ Bank-note.

BY SARAH TYTLER.

Noblesse Oblige.

The Hugrenot Family.

What She Came Through.

Beauty and the Beast.

The Bride's Pass.

Salnt Mungo's City.

Dissppeared.

Lady Bell.

Buried Diamonds.

The Blackhall Ghosta

BY C. C. FRASER-TYTLER. Mistress Jndith.

BY ALLEN UPWARD,

The Queeu against Owen.

BY ARTEMUS WARE,

Artemus Ward Completo.

BY WILLIAM WESTALL,

Trust-Moueg.

BY MRS, F, H, WILLIAMSOH. A Chill Widow.

BY J. S, WIRTER.

Cavalry Life.

Regimental Legends.

BY H. F. HOOD.

Passenger from Scotlend Tard.

Englishmen of the Rue Osin 
ALPHABETICAL CATALOGUE OF BOOKS

IN

GENERAL LITERATURE AND FICTION

PUBLISHED BY

ChatTo \& Windus

i i St. Martin's Lane, Charing Cross

Telegrams

Bookstore, Londor

LONDON, W.C.

Telephone No.

3524 Central

ADAMS (W. DAVENPORT), Books by.

A Dictionary of the Drama: A Guide to the Plays, Playwrights, Players, and Playhouses of the United Kingdom and America, from the Earliest Times to the Present. Vol. I. (A to G). Demy 8 ro, cloth. 10s. 6d. net.-Vol. 11., completing the Work, is in preparation.

Quips and Quiddities. Selected by UV. D. ADAMS. Post 8vo, cloth, 2s. 6d.

AGONY COLUMN (The) of 'The Times,' from 1800 to 1870 . Edited by alice Clay, Post 8vo, cloth, 2s. $6 d$.

ALDEN (W. L.). - Drewitt's Dream. Crown 8vo, cloth, $6 s$.

ALLEN (GRANT), Books by. Moorland Idy11s. Crown $8 v^{\circ}$, cloth, $6 s$. Post-Prandial Phtlosophy. Crown 8vo, art linen, 3 s. $6 d$.

Crown 8vo, cloth, 3s. 6.\%. each; post Evo, illustrated boards, 2s, each.

Babylon. With 12 Illustrations.

Strange Stories.

The Beckoning Hand.

For Maimie's Sake.

Philistia. In all shades.

The Deyil's Dle.

This Mortal Coll.

The Tents of Shem.

The Great Taboo.

Dumaresq's Daughter.

Under Sealed Orders.

The Duchess of Powysland.

Blood Royal.

Iyan Greet's Masterplece.

The Soally wag. With 24 Illustrations. At Market Yalue.

The Tents of Shem. EDITION, medium 8vo, 6 d.

Babylon. Cheap EDIrIon, post 8vo, cluth, 1s. net.

ANDERSON (MARY). - Othello's Occupstion. Crown 8vo, cloth, 3s. $6 d$.

ANTROBUS (C. L.), Novels by. Crown 8vo, cloth, 6s, each.

Quallty Corner. I Wlldersmoor. The Yine of Finyarra.
ALEXANDER (Mrs.), Novels by. Crown 8vo, cloth, 3s. 6\%. each; post 8vo, picture boards, 2s. each.

Yalerle's Fate. Mona's Choice. A Life Interest. Woman's Wit.

Crown 8vo, cloth, 35. 6d. each,

The Cost of her Pride.

A Colden Autumn.

Barbara, Lady's Maid \& Peeress. Mrs. Crichton's Creditor.

A Missing Hero.

A Fight with Fate.

The Step-mother.

Blind Fate. Post $8 \mathrm{vo}$, picture boards, 2s.

ALMAZ (E. F.).-Copper under the Gold, Crown 8ro, cloth, 6s.

APPLETON (G. W.), Novels by. Rash Conclusions. Cr. 8 vo, cl, 3s. 64 . The Lady in Sables. $\mathrm{Cr} .8 \mathrm{vo}, \mathrm{cl}_{.0} 6 \mathrm{~s}$.

ARNOLD (E. L.), Storles by: The Wonderful Adyentures of Phra the Phonician. Crown 8vo, ctoth, with 12 Illustrations by $\mathbf{H}$. $\mathbf{1 1}$. Paget, 35. 6d.: post 8ro, illistraled boards, $2 s$.

The Constable of $8 t$. Nicholas. With a Frontispíce. Crown 8 ro, cloth, 35. 6. ; picture cloth, fat back, $2 s$.

ARTEMUS WARD'S Works. Crown 8vo, cloth, with Portrait, 3s. 6d,: post $8 v^{\circ}$, Illustrated boards, $2 s$.

ASHTON (JOHN), Books by. English Carlcatureand Satire on Napoleon the First. With 115 lilustrations. Crown 8vo, cloth, 7s. 6d.

Social Life in the Relgn of Queen Anne. With 85 Illustrations. Crown Svo, cloth, 3s. $6 d$.

Crown 8 vo, cloth, 6s. each.

Boclal England under the Regency. With 90 lllustrations.

Florizel's Folly: The Story of Georar IV. and Mrs. FITZHERBERT. With 13 lllustrations. 
ART. - For details of three important Series of liacsimiles in Colour of selected Works of The Early Palnters of the Netherlands, of The Early German Palnters, and of Italian Painters of the XVth and XVIth Centuries, sce speclat Prospectus, to be liad upon application.

AUSTEN (JANE), The Works of : The ST, MARTIN'S EDITION in Ten Volumes, each fllustrated with Ten Reproductions after Water-colours by A WALLIS MILLS. With Bibliographical and Biographical Notes by R. BRIMLEY Jonssos. Pust 8vo, cl, 3s. b̆d nel per rol. The Norels will be arranged in the following ordcr, and the lirst volumes will be published in the Spring of 1908 . Vols. 1. and 11. PRIDE AND PREJUDICE: Vols. III. and IV, SENSE AND SENS1. I3ILITY: Vol. V., NORTHANGER ABEEY: Vol. Vi, PERSUASION Vols. VIl. and VIII., ENMA ; Vols. IX. and $\mathrm{X}$, MANSFIELD PARK.

AUTHORS for the POCKET. $16 \mathrm{mo}$. clotin, 2s. nel ea.: lcallier, $3 s$. net ca. The Poclret R. L. S.

The Pocket Thackeray.

The Pocket Charles Dickens.

The Pocket Richard Jefferies:

The Pocket Georgo MacDonald.

The Pocket Emerson.

The Pocket Thomas Hardy.

The Pocket George Eliot.

The Pocket Charies Kingsley.

The Flover of the Mind.

The Pocket Ruskin.

The Pocket Lord Beaconsfield.

BACTERIA, Yeast Fungi, and Allled Species, A Synopsis of. By W. B. Grover, B.A. With 87 lllustrations. Crown 8vo, cloth. 3s. $6 d$.

BARDSLEY (Rev, c. W.).English Surnames: Their Sources and Significations, $\mathrm{Cr}, 8 \mathrm{vo}$, cloth, 7s. 6it.

BARING-GOULD (S.), Novels by. Crown $8 v o$, clolh, $3 s .6 d$. e.3ch ; post $8 v^{\circ}$, illustrated boards, 2s. each; POPULAR EDITrons, mediun 800 , 6d. each.

Red Splder. I Eve.

BARR (AMELIA E.).-Love will Venture in. Cr. $8 \%$, cloth, $3 s .6 d$.

BARR (ROBERT), Stories by. Crown 8vo, cloth. 3s. 6d. each.

In a Steamer Chair. With 2 Illusts.

From YKhose Bourne, \&c. With 47 Illustrations by HAL HURST and olhers.

Revenge! With I2 Hllustrations by LANCELOT SPEED and others.

A Woman Interyenes:

A Prince of Good Felloys. Will, 15 lliustrations by E. J. SULLIVAN.

Crown 8vo, cloth, 6s, each.

The Speculations of John Steele.

whe Unchanging East.
BARRETT (FRANK), Novels by.

Post 8vo, illust. bds.. 2s, ea.; cl., 2s. 6d. ea.

The Sin of Oiga Zassoulioh.

Folly Morrison.

Little Lady Linton.

Honest Dayle. I Found Guilty. John Ford; and His Helpmate.

A Recolling Yengeance.

Lleut. Barnabas.

For Loye and Honour.

Cr. Svo, cloth, 3s. 6d. each; posl 8vo, illust. boards, $2 s$, each ; cloth limp, 2s. $6 d$, each.

Between Life and Death.

Fettered for Life:

A Missing Witness. With S lllus. trations by W. H. NARGETSON.

The Woman of the Iron Bracelets. Tho Harding Scandal.

A Prodigal's progress.

Crown 8vo, cloth, 3s. 6d. each.

Undor a Strange Mask. With ig Illustrations by E. F. JREEVTNALL.

Was She Justified?

The obliging Husband. With coloured Frontispiece.

Crown 8vo, cloth, 6 s. each.

Lady Judas.

The Error of Her Ways.

Fettered for Life. Polular EdITION, medium Svo, 6 ?

B A S K E R VILLE (JOHN) : A Memoir. By Ralph StRats and $k, K$. DENT. With i3 Plates. Large quarto, buckram, 2is, net.

BATH (The) in Diseases of the Skin. By J. L. Miltox. Post 8vo, is.; cloch, is. 6 .

BEACONSFIELD, LORD. By T. 1'. O'CONNOR, M.P. Crown' $85^{\circ}$, eloth. 5.

BECHSTEIN(LUDWIG), and the Brothers GRIMM.-As Pretty as Seven, and other Stories with o8 JIlustrations by RicilTER. Square $80^{\circ}$, cloth. 6s. 6r. ; gilt edecs, 7 . Ku;.

BEDE (CUTHBERT).-Mr. Ver dant Green. With 65 lliustrations. Post Sro, is. net.

BENNETT (ARNOLD), Novels by. Crown $8 \%$, cloth, os. each.

Leonora. I A Great Man.

Teresa of Watling Street. Witl 8 Illustrations by FRANK GILLETT.

Tales of the Five Towns.

Sacred and Profane Loye.

Hugo. | The City of Pleasurc. Crown 8vo, cloth, 3s, 6i, each.

Anna of the Five Towns.

The Gates of Yrath.

The Ghost.

The Grand Babylon Yots?. Crown 8ro, cloth, 3s. 6d.; POPUlar Editiox; medium sro, 6it.

BENNETT (IV. C.).-Songs for Sallors. Pust Sw, cloth, 25. 
BESANT and RICE, Novels by. Cr. 8vo, cloth, 3s. Gd. each ; post 8vo, illust, bds. 2s. each ; cl. limp, 2s, $6 d$. each.

Ready-Money Mortiboy.

The Golden Butterfly.

My Little Girl.

Yith Harp and Crown.

This Son of $Y$ ulcan.

The Monks of Thelema.

By Celia's Arbour.

The Chaplain of the Fleet,

The Seamy Side.

The Case of Mr. Lucraft.

'Twas in Trafaltar's Bay.

The 'Ten Ycars' Tenant.

BESANT (SIr WALTER), Novels by. Crown 8 ro, cloth, 3s. 6 $d$. each; post $8 \mathrm{vo}$, illustrated boards, $2 \mathrm{~s}$. cach; cloth limp, ss. 6d, each.

A11 Borts and Conditions of Men. Wilh 12 Illust ratlons by FRED. BARSARD.

The Captatn's Room, \&c.

All In a Garden Fair. With 6 Illus trations by HARRY FuRNiss.

Dorothy Forster. With Frontispiece.

Uncle Jack, and other Slories.

Children of Gibeon.

The World Went Yery Well Then. IVith 12 llluatrations by A. FORESTIER.

\section{Herr Paulus.}

The Bell of St. Paul's.

For Faith and Freodom. Will Illusts, by A. FORESTIER and F. WADUY.

To Call Her Mine, \&c. With 9 llustrations by A. ForestIEle.

The Holy Rose, \&c, With Frontisplece.

Armorel of Lyonesse. With 12 Illustralions by F. BARNARD.

St. Katherine's by the Xoxyer. ivith 12 Illustrations bv C. GREEN.

Yerbena Camellia Stephanotis.

The Ixory Gate.

The Rebel Queen.

Beyond the Dreams of Axarice. With I2 Illustrations by W. H. HYDE.

In Deacon's Orders, \&c. With Frontis. The Reyolt of Man.

The Master Craftsman.

The City of Refuge. Crown 8 vo. cloth 3s. 6it. each.

A Fountain Sealed.

The Changeling.

The Fourth Generation.

The Orange Girl. With 8 lllustrations by F. PEGRAM.

The Alabaster Box.

The Lady of Lynn. With i2 Illustrations by G. DEMAIN-HAMMOND.

No Other Yay. With I2 lllustrations by C. D. WARD.

Crown 8 vo, picture clolh, flat back, 25. each. St. Katherlne's by the Tower.

The Rebel Queen.

LAKGE TYPE, FINE PAPER EDITIONS, pot! $8 v o$, clolh, gilt top, $2 s$. net cach; leather, gilt edges, 35 . net each.

London.

Yestminster.

Sir Richard Whittington.

Gaspard de Coligny.

All Sorts and Conditions of Men.l
BESANT (Sir Walter)-continued.

POPUlaR EDITIONS. inedium 8:0, $6 d$. each.

III Sorts and Conditions of Men.

The Golden Eutterfly.

Ready-Money Mortiboy.

The Chaplain of the Fleet.

The Monks of Thelema.

The Orange Girl.

For Faith and Freedom.

Children of Glbeon.

Dorothy Forster.

Demy 8vo, cloth, 7s. 6d. each.

London. IVilli 125 lilustrations.

Yestminster. Vith Elching by F.S. IV ALKER, and i 30 llluslrations.

South London. With Elching by li. S. WALliER, and Is 8 Illustrations.

East London. With Etching by F. S. IVALKLE, and 56 Illusirations by I'HIL MAY, L. RAVEN IIILL, and J. PEXNELI.

Jerusalem. HY WALTER BESANT and E. H. PAI.AHE. Wilh Map and 12 Illusts. Crown 850 , buckram, 6 s, each.

As We Are and As WY May Be. Essays and Historiettes.

The Eulogy of Richard Jefferies.

Crown 8vo, clotb, 3s. 6d. each.

Fifty Years Ago. With i 44 Illusts.

Gaspard de Colligny. With a Portrait.

Sir Richard Whittington.

The Charm, and other Drawing-ronn Plays. With 50 lllustrations by CHRIS HAMMOND. \&c.

Art of Fiction. Fcap. 8 vo, cloth, is. net. BEWICK (THOMAS) and His Puplis. By Austin DoBson. With 95 Illusirations. Square 8vo, cloth, $3 s .6 d$.

BIBLIOTHECA ROMANICA : $A$ series of the Classics of the Romance (French, Italian, Spanish, and Portuguese) Languages: the Origiual 'Text. with Notes and Introductions in the original language. Small $8 v 0,8 d$.

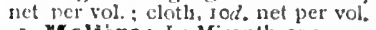

I. Moliere: Le Misanthrope.

2. Moliere: Les femmes savantes.

3. Corneille: Le Cid.

4. Descartes: Discours de la méthorle.

5-G. Dante: Divina Commedia I.: Inferno.

7. Boccaccio: Decameron: Prima yiornata.

8. Calderon : La vida es sucño.

9. Restif de la Bretonne: L'an 2000.

so. Camões: Os Lusiadas : Canto I., 11 .

Ir. Racine: Athalie.

12-15. Petrarca : Rerum vulgarium fragnenta.

16-17. Dante: Divina Commedia II.: Purgalorio.

18-28. Tillier: Mon oncle Benjamin.

21-22. Boccaccio: Decameron: Seconda griornata.

23-24. Beaumarchais: Le Barbier de Sèville.

25. Camoes: Os Lusizdas: Canto III., 
BIBLIOTHECA ROMANICA-

(continued).

26-28. Alfred de Musset : Comédies et Proverbes: Là Nuit vénitienne: André del Sarto; Les Caprices de Marianne: Fantasio; On ne badine pas avec l'amour.

29. Cornellle: Horace.

30-31. Dante: Divina Commedia 111 . Paradiso.

32-34. Preyost: Manon Lescaut.

35-36. CEuyres de Maitro Françols Yillon.

37-39. Guillem de Castro: Las Mice. dades del Cid, I., II.

40. Dante: La Vita Nuova.

41-44. Ceryantes: Cinco Novelas ejemplarcs.

45. Camões: Os Lusiadas: Canto V., Vi., vil.

46. Mollère: L'Avare.

47. Petrarca: I Trionfi.

48-49. Boccacclo: Decameron: Terza giornala.

5o. Corneille: Cinna.

BIERCE (AMBROSE).-In the Midst of Life. Crown 8vo, cloth, 3s. $5 d$.; post 8 vo, illustrated boards, $2 s$.

BILL NYE'S Comic History of the United States. IVith 146 Illusts. by F. OPPER. Crown 8 vo, cioth, 3s. $6 d$.

BINDLOSS (HAROLD), Novels by. Crown 8vo, cloth, 6s. each.

The Concession-Hunters.

The Mistress of Bonayenture.

Dayentry's Daughter.

A Sower of Wheat. Cr. 8 vo, cl., 3 s. $6 d$.

Ainslie's Ju.Ju. Crown 8vo, cloth, 3s. $6 d$.; picture cloth, flat back, $2 s$.

BLAKE (WILLIAM), The PoetIcal Works of. Edited by E. J. ELLIS. In 2 Vols., each with Photogravure Frontispiece, small demy $8 v o$, buckram, 12s. net; haif-ieather, I5s. net

Tho Real Blake : A Portrait Biography by E. J. ELLIS. With 13 Illustrations, Demy Svo. buckram, i2s. net.

Willam Biake: A Critical Study by A. C. Swinberse. With a Portrait. Crown $8 r^{\circ}$, buckram, 6s. net.

Wllliam Blake: Etchings from his Works (8 Steel Plates and 2 Lithographs) by W. H. Scotr. Colombier folio, halfcloth, r2s. 6i.net.

BLUNDELL'S Worthies, 1604 1904. By M. L. Banks, M.A. With 10 Illustrats. Demy 8vo, cloth, 7s. $6 d$. net.

Boccaccio. - The Decameron. With a Portrait. Pott 8 vo, cloth, gill top, $2 s$. net ; leather, gilt edges, 3s. nel.
BODKIN (Mc.D., K.C.), Books by. Dora Myrl, the Lady Detectiye. Cr. 8ro, cl., $3 s .6 d$.: picture cl, that back, 2s.

Crown 8ro, cloth. $3 s .6 d$. each.

Ghillelagh and Shamrook.

Patsey the Omadaun.

BOURGET (PAUL).-A Living Lle. Translated by JoHN DE VILliERS. Crown $8 v 0$, cloth, 3s. $6 d$.

BOYD.-A Versailles Christmas tIde. By MIARY STUART BOYD. With 53 Illusts, by A.S. BOYD. Fcap. 4 to, cl.. 6 s.

BOYLE (F.), Works by. Post $8 \% 0$, illustrated boards, 2s. each.

Chronicles of No-Man's Land.

Camp Notes. | Sayage Life.

BRAND (JOHN)._-Observations on Popular Antiquities. With the Addilions of Sir HENRY EL.LIs. Crown 8vo. cloth, 3s. 6 d.

BRAYSHAW (J. DODSWORTH). -Slum Sllhouettes : Stories of London Life. Crown 8vo, cloth. 3s. 6 d.

BREWER'S (Rev. Dr.) Dictionarles. Crown $8 v o$, cloth, 3s. $6 \pi$, each.

Thereader's Handbook of Famous Names in Fiction, Allusions, References, Proyerbs, Plots, Storles, and Poems.

A Dictionary of Miraoles: Initative, Realistic, and Dogmatic.

BREWSTER (SIr DAVID), Works by. Post $8 r^{\circ}$, cloth, $4 s .6 a$. each. More Worids than One: Creed of Philosopher, Hope of Cliristian. Plates.

The Martyrs of Solence: Galileo, TYCHO BRAHE, and KEPI.ER.

Letters on Natural Maglo. With numerous Illustrations.

BRIGHT (FLORENCE).-A Girl Capitalist. Crown 8vo cloth, 6 s.

BRILLAT =SAVARIN. - Gastronomy as a Flne Art. Translated by R. E. ANDERso:. Post 8vo, half.cl., 2s.

BRYDEN (H. A.).-An Exiled Scot. With Frontispiece by J. S. Cromptos, R.1. Crown 8vo, cloll, 3s. 6 d.

BRYDGES (HAROLD). - Uncle Sam at Home. WVith gr lllusts. Post 8 vo, illust, boards. $2 s$. : cloth limp, $2 s .6 d$.

BURGESS (GELETT) and WILL IRWIN. - The Plcaroons: A San Francisco Night's Eotertainment. Crown 8vo. cloth. 3s. 6 d.

BURNS (ROBERT).--The Cot ter's Saturday Night. Wilh Illustrations by A.S. BOY D. Fcap. 4 lo, cl., $6 s$, net.

BURTON (ROBERT). - The Anatomy of Melancholy. With a Photogravure Frontispiecc. Demy 8 ro, cloth, 7 s. $6 d$. 
BUCHANAN (ROBERT), Poems and Novels by.

The Complete Poetloal Works of Robert Buohanan. 2 Vols., crown 8 vo, buckram. with Portralt Frontisplece to each volume, I2s.

Crown 8vo, clolh, $3 s .6 d$. each: post 8 vo, illustrated boards, 25 . each.

The Shadow of the Sword.

$\bar{A}$ Child of Nature.

God and the Man. With II Illustra. tions by F. BARNARD.

Lady Kilpatrick.

The Marty rdom of Madeline.

Loye Me for Eyer.

Annan Water. I Foxgloyo Manor. The Ney Abelard. | Rachel Dene. Matt: A Story of a Caravan.

The Master of the Mine.

The Heir of Linne.

Woman and the Man.

Crown 8 vo, c!olh, 3s. Gd. each.

Red and White Heather.

Andromeda.

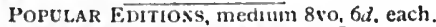

The Shadow of the Sword.

God and the Man.

Foxglove Manor.

The Charlatan. By ROBERT BuCHANA. and HENRY MURRAY. Crown 8vo, cloth, with Frontispiec 2 by T. H. RoBInsos, 3.s. $6 d$.; post 8 vo, illnstrated boards, $2 s$.

CAINE (HALL), Novels by.

Crown $8 \mathrm{vo}$, cloth. $3 s$. 6d. each; post $8 \mathrm{vo}$. illustrated boards, $2 s$. each; clotls limp, 2s. 6d. each.

The Shadow of a Crime.

A Son of Hagar. | The Deemster.

Also LIBRARY EDITIONS of the three novels, crowı $8 \%$, cloth. $6 s$, each ; CIIEAP POPU. LAR EDITIONS, medium 8vo,portrait cover, 68. each: and the FIXE PAPER EDITION of The Deemster, pott 8 vo, cloth, gilt top, 2s. net : leather, gill edges, 3s. net.

CAMERON (V. LOVETT). - The Cruise of the 'Black Prince' Privateer. Cr. 8vo, cloth, with 2 Illus trations by P. Ml ACNAB, 3s. 6d. ; post 8 vo, picture boards, 2. .

CAMPBELL (A. GODRIC). Fleur-de-Camp: a Daughter of France. Crown svo, cloth. 6s.

CAPTAIN COIGNET, Soldier of the Empire. Edited by LOREDAN LARCHEY, aud Translated by Mrs. CAREY. With soo lllusts. Cr.8vo, cloth, 3e.6d.

CARLYLE (THOMAS).-On the Cholce of Books. Post 8 vo. clnth Is. $6 d$.

CARROLL (LEWIS). - Alice in Wonderland. With 12 Coloured and many Line Illustrations by MILLICENT SOWERBY. Large crown 8vo, clolh gill, 5s. net. (Published on Oct. I, by special arrangement with Messrs, Macmilian \& Co.)
CARRUTH (HAYDEN). - The Ad. ventures of Jones. With 17 lllustrat'ns. Fcap. 8vo, picture cover, is. : cloth, is. $6 d$.

CHAMBERS (ROBERT W.), Stories of Parls Llie by.

The King in Yellow. Crown 8vo, cloth, 3s. $6 d$.: fcap. 8vo, clotlı linup, $2 s .6 d$.

In the Quarter. Fcap. 8vo, cloth, 2s.6

CHAPMAN'S (GEORGE) Works. Vol. I.. Plays Complete, including the Doubtful Ones. - Vol. I1.. Pocms and Minor Translations, with Essay by A. C. SwINBLRNE, - Vol. 111.. Translations of the Illad and Odyssey. Three Vols., crown 8vo. cloth, 3s. 6d. each.

CHAUCER for Children: A Golden Key, By Mrs, H. R. HAWEIS, With 8 Coloured Plates and 30 IVoodcuts. Crown 4 lo. cloth, 3s. 6d.

Chaucer for Schools. With the Story of his Times and his IVork. By Mrs. H. R. HAwEIS, Demy 8 vo, cloth, $2 s .6 d$.

CHESNEY (WEATHERBY). The Cable-man. Crown $8 \% 0$, cloth, $6 \mathrm{c}$.

CHESS, The Laws and Practice of. WVill an Analysis of the Openings. by Howard STAUxTON, Edited by R. B. WormaLD, Crown 8vo, cloth, 5s.

The Minor Tactics of Chess: A Treatise on the Deployment of the Forces in obedicnce to Strategic Principle. by F. K. Yousg and E. C. HowELL. Fcap 8vo, cloth, 2s. 6 d.

The Hastings Chess rournament. The Authorised Account of the 230 Games played Aug.-Sept., 1895. WVith Annotations by PILLSBURY, LASKER, TARRASCH, STEINITZ, SCIIFFERS, TEICIMANN, BARDELEBEN BLACKBURNE, GUNSBERG, TIXSLEY, MASON, and AZBIN : Biographical Sketches, and 22 Portraits. Edited by H. F. CHESIIRE. Crown 8vo, cloth. 5s.

CHILD=LOVER'S CALENDAR ('THE). With Col'd Illusts. by AMeliA BAL ERLÉ. $16 \mathrm{mo}$, coloured boards, is. net.

CLARE (AUSTIN), Stories by.

For the Love of a Lass. Post 8 vo, illustrated boards. $2 s$.

By the Rise of the Riyer. Crown $8 v o$, cloth. 3s. 6 d.

Crown svo, cloth, os, each.

The Tideway.

Randal of Randalholme.

CLIVE (Mrs. ARCHER), Novels by. Post 8 vo. cloth. $3 s .6 d$. each; illus. trated boards, 2s. each.

paul Ferroll.

Why Paul Ferroll Killed his Wife. CLODD (EDWARD). - Myths

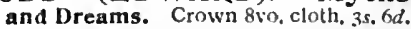
COLLINS (J. CHURTON, M.A.), Books by. Cr. 8 vo, cloth. 3s. 6d, each. Illustrations of Tennyson.

Jonathan Swift. 
COBIA N (J. MA C LAREN), Novels by.

Tho Cure of Souls. Post 8ro, illustraled boards, $2 s$.

The Red Sultan. Crown svo, cloth, 3s. Gr.; p post $8 r o$, illustrated boards, $2 s$.

The Burden of Isabel. Crown svo, cloth, 35. 6i.

COLLINS (MORTIMER and FRANCES), Novels by Cr.sro, cl. 3s. 6\% each: post 8vo, illustd. bds., 2s. each. From Midnight to Midnight.

You Play me Faise.

Blacksmith and Scholar.

The Yillage Conedy.

Frances.

l'ost $85^{\circ}$, illustraled boards, $2 s$, each.

Transinigration.

A Fight with Fortune.

Sweet Anne Page.

Sweet and Twenty.

COLMAN'S (GEORGE) Humorous Works: 'Broad Grins,' 'I Nightgown and Slippers,' \&c. With Life and Frontis. Crown 8vo, cl. 3s. 6d.

\section{COLOUR $=$ BOOKS.}

Large foolscap 4 to, clollı, 20 s, net each.

* Sxitzerland: The Country and its Peoplo. By ClAREXCE ROOk. With 56llitustrations in Three Colours by Mrs. TANES / ARDINE, and 24 in TwO Tints.

The Colour of London. Isy kev. W. J. LOFTIE, F.S.A. Witl Introduction by I. H. SPIELNA.x, H.S.A., and Illustrations in Three Colours and Sepia by Yoshio Makiino.

- Tho Colour of Paris. Ly several Frexcil ALTHORs, Jllustrated in Three Culours and Sepia by the Japanese arlist, Yosulo MALkiso. [Preparing

Cairo, Jerusalem, and Damascus. By D. S, MARGoliot'TI, Lit.D, WVith lliustrations in Three Colours by W. S. S. TYRWUITT, R.B.A., and REGINALD LAYRATT, A.R.IV.S.

Tho Rhine. By H. J. MACKINDER. Vith Illusirations in Three Colours by Mrs. JAMES JARDINE, and Two MIaps.

* Essisi of St. Francis. By Mrs. ROBERT GOFF, With lntroduction by I. KERR LAWSON, 1lustrations in Tluree Colours by Colonel R. Govk, and Reproduclions of the clief Franciscan Paintings.

cDeyonshire: its Moorlaring Streams, and Coasts. By Lady ROSALIND NORTHICOTE. With Illustralions in Three Colours by F. J. IVIDGERY.

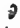

[Preparing

I arge foo:scap 4 to, eloth, jos. 6\%. net each.

Yonice. BY BERYL DE SÉLINCOURT and MAY STURGE-HENDERSOX. With 30 Illus trations in Three Colours by REGINALD J3ARRATT, A.R.IVS.

Lisbon and Cintra: with some Account of other Cities ard Sites in Portugal. By A.C. 1xchBOLD. VIith 30 lllustrations in Three Colours by STANt.ry I.ICtBOI.D.

[N $\boldsymbol{N}_{0}$
COLOUR-BOOKS-intinued.

From the Foreland to Renzance: Ports and Harbours of the South Coast. By Clive Hollaki. With numerous Illustrations in Three Colours by MAURICE RANDALL.

* * Prospectuses of these Books, titith details also in regard to SPECIAL COPIES on pure rag raper of those marked , may be had.

COLLINS (WILKIE), Novels by. $\mathrm{Cr} .8 \mathrm{ro}, \mathrm{cl}, 35.6 \mathrm{~d}$. each; post $8 v 0$, picture boards, $2 s$. each ; cl. limp. 2s, 6d. each.

Antonina. | Basil. | Hideand Seek The Yoman in Yhite.

The Moonstone. I Man and W1fe: The Dead Secrot. | After Dark. The Queen of Hearts.

INo Namg | My Miscellantes,

Armadale. Poor Miss Finch. Miss or Mrs.? I Tho Black Robe. The New Magdaten.

Frozen Deep.| $A$ Rogue's Lifo.

The Law and the Lady.

The Tyo Destinies.

The Haunted Hotel.

The Fallen Leayes.

Jezebel's Daughter.

Heart and Science. 'I Say No.'

The Eyil Genius. I Litie Noyels. The Legacy of Cain. | Blind Love. Popular EDitions, mediun 8vo, 6d, eacl. The Woman in White.

Moonstone. I The New Mardalen. The Dead Secret. | No Name.

Man and $\boldsymbol{X}$ ife

Whe Woman in White. LARGE TVPE, FINL PAPER EDITION. Pott 8vo, cloth, gill top, $2 s$, net : leather, gilt edges, $3 s$. net.

The Frozen Deep. LARGE TYPE EDIT. Fcap. svo, cl., Is. net ; leather, Is. $6 d$. net.

COLQUHOUN (M. J.).-Every Inch a Soldier. Crown 8vo, clotl, $3 s .62 . ;$ post $8 v 0$, illustrated boards, 25 .

COLT-BREAKING, Hints on. By V. M. Hutchison. Cr. Svo, cl., 3s. $6 \%$.

COLTON (ARTHUR). - The Belted Seas. Crown 8vo, cloth, 3s. 6\%.

COMPENSATION ACT (THE), 1906: Who pays, to whom, to what, and when it is appilicable. By A, CleneNt Edwaris, M.P. Croviı $8 v 0$, is. net; cloth. is. 6d. net.

COMPTON (HERBERT), Novels by. The Inimitable Mrs, Massingham. Crown 8vo, cloth, 3s. 6d. Crown sio, eloth, 6s, each.

The Wiful Yay.

The Queen can do no Wrong.

To Defeat the Ends of Justico.

COOPER (E. H.), Novels by.

Geoffory Hamilton. Crown svo, cloth, $35.6 d$.

The Marquis. Crown $5 r o$, clolh, $6 s$. CORNISH (J.F.).-Sour Grapes. Crown 8\%o, clolh, $6 s$. 
C O R N W A L L. P o p u I a r Romances of the West of England: The Drolls, 'Iraditions, aud Superstitions of Old Cornwall. Collected by ROBERT IIUNT, F.K.S. With two Piates by GeOrge Cruiksirank. Cr.8vo, cl, 7 s. Gl.

COURT (The) of the Tuileries, 1852 to IS70. By LE PETIT HOMME. Roce. With a Frontispiece. Crowll 8vo, cloth, 7s. 6d. wet.

COVENT GARDEN THEATRE, Tie Annals of, from 1732 to 1897 . By HEXRY SAlE WYYDHAM. With 45 lllustrations. 'Two Vols, demv Sro, cl, 2Is. net

CRADDOCK (C. EGBERT), by.

The Prophet of the Great Smoky Mountains. Crown $8 v o$, cloth, $3 s$. 6it.: post $8 v 0$, lltustrated boards, $2 s$.

fis Yanished Star. Cr 8 vo, cl, $3 s .6 \%$. The Windfall. Crown 8vn, cloth, 6s.

CRESSWELL (HENRY). - A Lady of Misrule. Crown 8vo, cloth G.s.

CRIM (MATT).-Adventures of a Fair Rebel. Crown $8 \mathrm{vo}$, cluth, $3 \mathrm{~s} .6 \mathrm{t}$, ; post 8 vo, illustrated boards, $2 s$.

CROCKETT (S. R.) and others. Tales of our coast. By $S$. $R$. Crocket, Gilbert Parker, harold FREDERIC, 'Q.,' and W.CIARK RL'SSELL With 13 Iltustrattons by FrANk BRANGwys. Crown 8vo, eloth. 3s. 6 .

CROKER (Mrs. B. M.), Nove!s by. Crown 8vo, cloth, 35. Go. each post $8 \mathrm{vo}$, illustrated boards, $2 s$. each cloth limp. 2s. 6it, each.

Pretty Miss Nevilie.

A Bird of Passage. Mr. Jeryis. Dlana Barrington.

Two Masters.

A Family Likeness.

A Third Person. | Proper Prldc. Yillage Tales \& J unglo Tragodies. The Real Lady FIllda.

Married o: Single?

Crown 8\%o, cloth, 3s. 6, each.

In the Kingdona or Kerry:

Miss Balmaine's past.

Jason. | Beyond the Paie.

Terence: With 6 Illusts, by $S$. P'AGET.

The Cat's-paw. With i2 Illustritions by liRED PEGRM.

Tho Spanish Neckiace. With 8 Illustrations by F. I'Jera.I.

Crown 8vo, cloth, 3s. 6d. each : post 8vo, cloth limp, 2s. 6d, each.

Infatuation. Some one Else.

'To Let.' Post 8vo, picture boards, 25. cioth limp, $2 s, 6 d$.

Poptiar EDItIoNs, nedium 8vo, 6d. each. Diana Barrington.

Pretty Miss Nevilic.

$\boldsymbol{x}$ Bird of Passage.

Beyond the Pale.

A Family Ltkeness.
CRUIKSHANK'S COMIC AL-

MANACK. Complete in Two SERIES. The FIRST from I835 to 1843; the SECOND, from 1844 to 1853 . A Gathering of the Eest Humour of THACKERAY, HOOD, ALBERT SMITI, \&c. With numerous Steel Engravings and Woodcuts by Cruikshanis, LANDELIS, \&c. Two Vois., crown 8vo, cloth, 7s. 6d. each.

The Life of George Cruikshank. By BLANCHARD JERROLD. With 84 IIIl1strations and a Bibliography, Crown $80^{\circ}$, cloth. 3s. 6d.

CUMMING (C. F. GORDON), Works by. Demy svo, cloth, 6s. each

In the Hebrides. Witt 24 lliustrations. In the Hitmalayas and on tho Indlan Plains. With 42 lliustrations.

Two Happy Years in Ceylon. With 23 flltustrations.

Yia Corn yrall to Egypt. Frontis,

CUSSANS (JOHN E.).-A Hand= book of Heraidry; including instructions for Tracing Pedisrees, Deciphering Ancient MISS., \&c. With 408 Woolcuts and 2 Colrri. Plates, Crown 8vo, cloth, 65.

CYCLING, HUMOURS OF. By JEROME K JEROME, H. G. WELLS, BARRY PaIN, C. ROOK, PETT Ridge, J. F. Sull1VAN, \&c. With Illusts. Cr. 8vo, cl., 1s. nct.

DAUDET (ALPHONSE). - The Evangellst; or, Port Salvation. Transtited by C. If. ARELZER. Cr. Svo, cioth. 3s.6d. ; post 8vo. illustrated bds. 25.

DANBY (FRANK).-A Coquette in Crape. Foolscap 8 vo, cloth, 1s, net.

DAVENANT (FRANCIS).-Hints for Parents on the choice of a Profession for their Sons when Starting in Life. Crown $80 \%$, is. $6 d$.

DAVIDSON (HUGH COLEMAN). -Mr. Sadler's Daughters. Crown 8 vo, cloth, 3 s. $6 d$.

DAVIES (Dr. N. E. YORKE-), Works by. Cr. 8vo, Is. ea.: ci.. Is. $6 d_{\text {. ct. }}$ Ono Thousand Medical Maxims and Surgical Hints.

Nursery Hints: A Mother's Guide.

The Dietetic Cure of Obesity (Foods for the Fat). With Cliapters on the Treatment of Gout by Diet.

Alds to Long Life. Crown $8 \mathrm{vo}, 2 s$. ; cloth, $2 s .6 d$.

DAVIES' (Sir JOHN) Complete Poetlcal Works. Edited with Notes, by Rev. A. B. GROSART, D.D. Two Vols., crown $8 v 0$, cloth, 3s. $6 d$. each.

DEFOE (DANIEL). - Robinson Crusoe. With 37 lilusts, by GEORGe CRUIKSHANK, LARGK TYPE, FINE PAPFR EDition. Pott 8 ro, cloth, grit torn, 2s. net; ieather, giit edges, 3 s. net. 
DEAKIN (DOROTHEA), Stories by. Crown $8 \mathrm{vo}$, cloth, 3s. $6 d$. cach.

The Poet and the plerrot.

The Prinoess \& the Kitchen-maid.

DE GUERIN (MAURICE), The Journal of. OWith a Memoir by SAINTE. BEUVE. Fcap. 8vo, half-cloth, 2s, $6 d$.

DE MAISTRE (XAVIER).-A Journey Round my Room. Transl. HE.RY ATTWELl. Post S'o, ctoth, 2s, 6.t.

DEMILLE (JAMES).-AStrange Manuscript found in a Copper cyllnder. Crown 8vo, cloth, with 19 Jllustrations by GILBERT GALL, 3s. 6d. post 8\%o, illustrated boards, 25.

DEVONSHIRE SCENERY, The History of, by ARTHER W. CLAYDEN, II.A. With Illus. Demy 8vo.cl. . 10s 6d. net.

Devonshire: Its Moorlands, Streams and Coasts. By Lady ROSALIND NORTHCOTE. With Iltustra. tions in Three Colours by F. J. WIDGkRY. Large fcp. 4to, ctotls, 20s. net: a few Speclal Copies, with mounted plates. bound in parchment, 42s. [Preparing

DEIVAR (T. R.). - A Ramble Round the Globe. With 220 Jllustra. tiuns. Crown 8vo, cloth, 7s. $6 d$.

DICKENS (CHARLES), The Speeches of. Edited and Annotated hy K. H. SHEPHERD, With a Portrait. Pott 8 ro, cloth, 2 s, net; leather, $3 s$. net.

The Pocket Charles Dickens: being Favourtle Passages chosen by ALFRED H. HYATT. $16 \mathrm{mo}$, cloth, gilt lop. 2s, nel teather, gilt top, 3 s. net.

\section{UICTIONARIES.}

The Reader's Handbook of Famous Names in Fiction, Alluslons, References, Proyerbs, Plots, stories, and Poems. By Rev, E. C. BREWER, LL.D. Crown 8 so, ctoth. 3s. $6 d$.

A Dictionary of Miracles, Imitative, Realistic, and Dogmauc. By Rev. E. C. BREWER, LL.D Crown 8vo, cloth, 35. 6d.

Familiar Allusions. Dy Willias A. and CHARLES G. WheEler. Demy 8vo, cloth, 7s. 6d. net.

Familiar Short Sayings of Great Men. With Historicaland Exptanatory Notes by Samuel A. Be.it, A.M. Crown 8vo, ctoth, 7s. $6 d$.

The Blang Dictionary: Etymological, Historicat, and Anecdotal. Crown 8vo, cloth, 6s. 6d.

Words, Facts, and Phrases: A Dictionary of Curious, Quaint, and Outof-the-Way Matters. By EliEzer EDWARDS. Crown 8vo, cloth, 3 s. $6 d$.

DILKE (SIr CHARLES, M.P.). -The British Empire. Crown 8vo, buckram. 3s. 6 d.

UOBSON (W. T.).-Poetical Ingenuities and Eccentricities. Pos! 8 so, cloth, 2s. $6 d$.
DOBSON (AUSTIN), Works by. Thomas Bewick and his Pupils. Vith 95 lilusts. Sq. 8vo, cloth, 3s, $d d$.

Crown 8vo, buckram, 6s, each,

Four Frenchwomen, With Four Portraits.

Eighteenth Century Yignettes. in Three Series, each 6s, : also FisisPAPER EDITIONS of the THREE SERIES, pott 8vo, cloth, 2s. net each; leather, 3s. net each.

A Paladin of Philanthropy, and other Papers. With 2 lllusirations. Side-walk Studies. With 5 itlusts.

\section{DONOVAN (DICK), Detective} Stories by. Post svo. illustrated boards, 2s. each : clolh, 2s. $6 d$ each.

Caught at Last.

In the Grip of the Lax:

Link by Link.

From Information Recelyed,

Susplcion Aroused.

Ridales Read.

Tracked to Doom:

Crown 8vo, $\mathrm{ct}, 35$. od each ; picture $\mathrm{cl}$, fal back, 2s. each; post 8 vo. illustrated boards, 25 . each; cloth limp. 2s. $6 d$ eact.

The Man from Manchester.

The Mystery of Jamaica Terrace. Crown 8ro. ctoln, 3s. Od. each.

Deacon Brodie : or, Behind the Mask,

Tyler Tatlock, Private Detective. Cr. 8ro, ct., 3s. Od. ca. "pict. cl.. Hat bk'? 2s. ea. The Records of Yincent Trili. Tales of Terror.

Crown \&vo, cloth, 3s. Od. each ; posl $8 \% 0$, illustrated boards, 2s. each; cloth timp, 2s. 6 d each

Chronicles ol Michaol Daneyitch. A Detectiye's Triumphs.

Tracked and Taken.

Who Poisoned Hetty Duncan?

Crown 8vo, picture cloth, flat back, 2s. each : post $8 v 0$, illustrated boards, 2s. each; cloth limp, 2s. $6 d$. each.

Wanted 1

The Man.Hunter.

Dark Deeds. Crown 8yo, cloth limp, 2s. $6:$. ; picture clolh, flat back, $2 s$.

DOWLING (RICHARD). - OId Corcoran's Money, Cr. 8vo, cl. 3 s. $6 d$.

DRAMATISTS, THE OLD. Edited by Col. Crivisghas. Cr. 8 ro, ctoth, with Portraits, 3s. 6d. per Vol.

Ben Jonson's Works. With Noles, Critical and Explanatory, and a Biographical Memoir by WILliaM GIFFORD. Three Vols.

Chapman's Works. Three Vols. Vol, J. contains the Plays complete; Vol, II, Poems and Minor Translations, with an Essay by A. C. SWINBURNe; Vol. 111., Translations of the Iliad and Odyssey. Marlowe's Works. One Vol.

Massinger's Plays. From GtFFord's Text. Une Vol. 
DOYLE (A. CONAN). - The Firm of Girdlestone. Crown 8rn. cloth. 3.5. $6 d$.

\section{DUMPY BOOKS}

(The) for Chlidren. Rny. $32 \mathrm{mo}$ cloth. it. net e.

1. The Flamp, The Ameltorator, and The Scnool-boy's Apprentice. By F. V. Lucas.

2. Mrs. Turner's Cautionary Storles.

3. The Bad Family. By Mrs FFNWICK.

4. The Story of Little Black Sambo. HY HELEN BANNERMAN. illustrated in colours.

5. The Bountiful Lady. By Thovas Сови.

7. A Flower Book. lllustraled in colours by NELLIE Jienson.

8. The Pink Knight. IBy J. R. MoN SkLL. Illustrated in colours.

9. Tho Littlo Clown. By Tiomas CoBk.

10. A Horse Book. By MarY Tourtel lllustrated in colours.

11. Litcle People: an Alphabet. By HENRY MATFR and T. IV. H. CROSLAND llluslrated in colours.

12. $\boldsymbol{A}$ Dog Book. By Ethet, BickNet. With P'ictures in colours by CARTON MOORE PARK.

13. The Adventures of Samuel and Sellna. By JEA. C. ARCHER. Illuslrated in colnurs.

14. The Little Girl Lost. By Eleator RAPER.

15. Dollies. By RrChard Huster Illustrated in colours by RCTH COBB.

16. The Bad Mrs. Ginger. By Howok C. APlleins. lllustrated in colours.

17. Peter Piper's Practical Princlples. lliustrated in colours.

18. Litte White Barbara. El.pavnR MARCi1 Ilystrated iu colours

20. Towlocks and his wooden Horse. Hy ALICE M. APlikroN Illus, in colnurs by lHONOR C. APlLF.TON.

21. Three Little Foxes. By MARy TOURTEL. lllustrated in colours.

22. The Old Man's Bag. By T. W. H. CROSLAND. lllus. hv J.R. MONSELL

23. Three Littlo Goblins. By M G. TAGGART. lllustrated in colzurs.

27. Dumpy Proverbs. By HoNOR C. Applitos. Illustrated in colours.

25. More Dollies. By RICHARD HL: TER. Illus, in colours hy ReTH COBB.

26. Littlo Yellow Wang-10. Bj M. C. HEt.L. Illustrated in colours.

27. Plain Jane. TexibyG M.GeOrGe. Illusirated in colowse by G. M. C. FRS.

28. The Sooty Man. BY E. B. MACKISNON and EDEN COYBEF. lllus

29. Fishywinkle. By JEAxC. ARCHER. Illustrated in colours.

30. Rosalina. Iltustrated in colours by JEAS C. ARCIIR.

31. Sammy and the Snarlywink. lilusiraled in colours by LENA and NoRMAN ALLT.

33. Irene's Christmas Party. By IICIARD HE.TtER lius, by RUTUCOBB.
DUMPY BOOKS-continued.

34. The Littlo Soldier Book. By JkSSIE POPE. 11Justrated in colours by HENRY MAYRR.

35. The Dutch Doll's Ditties. By C. AUBREY MOORE.

36. Ten Littlo Nigger Boys. By NORA CASF.

37. Humpty Dumpty's Little Son. By HELEN R. CROSS.

DUNCAN ISARA JEANNETTE, Books by. Cr. 8ro, cloth, 75. 6d. each.

A Social Departure. With IrI illustrations by F. H. TowiseND.

An American Girl in London. With 80 Illustrations by $F$. 11. Towssriss.

The Simple Adventures of a Memsahib. With 37 llistrations. Crown 8vo, cloth, 35. od, cach.

A Daughter of To-Day.

Yernon's Aunt. With 47 llistrations. DUTT (ROMESH C.).-England and India: Progress during One Hundred Years. Crown 8 roo, cloth, 2.s.

DYSON (EDWARD). - In the Roaring Filties. Crown sw. cloth. fie.

EARLY ENGLISH POETS. Fdited by Rev, A. 13, Grosart, D.D. Crown 8vo, cloth, 35. 64. per Volume.

Fletcher's (Giles) Poems. One Vol. Dayles' (SIr John) Complete Poetical Works. Two Vols.

EDWARDES (Mrs. ANNIE), Novels by.

A Point of Honour. Post 8\%o, illustrated boards, 25.

Archle Loyell. Crown 8vo, cloth, 3s. 6 . : post 8vo, illustrated boards, 25.

A Plaster Saint. Cr. 8 vo, cloth, 3s. $6 d$.

EDWARDS (ELIEZER). Words, Facts, and rhrases: A Dictionarv of Curious, Quaint, and Out-of-thc-Vay Matters. Crown 8 vo, cloth, 3s, $6 d$.

EGERTON (Rev. J. C.).Sussex Folk and Sussex Wsys. With Four lllusts. Crown 8vo, cloth, 5s.

EGGLESTON (EDWARD). Roxy. Post 8*o, illustrated boards, 25.

ELBÉ (LOUIS). - Future Life in the Light of Ancient Wisdom and Modera Science. Crown 8 ro., cloth, 65, net.

ENGLISHMAN (An) in Paris: Recollections of Louis l'hilippe and the Empire. Crown 8vo, cloth. 3s. 6 d.

ENGLISHMAN'S HOUSE, The : A Practical Guicle for Selectingor Building a llouse. By C. J. RICHARDSON. With Coloured Frontispiece and 534 Illustralions. Crown 8vo, cloth. 3s. 6d.

EYES, Our: How to Preserve Them. liy Joux Browsixg. Crowa $8 v 0$, cloth, 5 . 
FAMILIAR ALLUSIONS: Nis- FI cellaneous Information, including celebrated Statues, Palntiugs, Palices, Country Seats, Ruins, Churches, Ships, Streets, Clubs, Natural Curiosities, \&c. By WV. A. and C. G. WhEELER. Demy Sro, cloth, 7s, 6it. net.

FAMILIAR SHORT SAYINGS of Great Men. By S. A. BENT, A.M. Crown 8vo, cloth, 7s. $6 d$.

FARADAY (MICHAEL), Works by, Post $8 v 0$, cloth, 4s. 6t. each.

Tho Chomical History of a Candle: Lectures delivered before i |uvenile Audience. Edited by WiLlia Clookis, F.C.S. With numerous llists.

On the Yarlous Forces of Nature, and thoir Relations to each other. Edited by IVILLIAM CROOKES, F.C.S. With Illustrations.

FARRER (J. ANSON).-War: Three Essays. Crown 8ro, cloth, is. $6 d$.

FENN (G. MANVILLE), Novels by. Crown sro, cloth, 3s. 6d. cach: post svo, illustrated boards, 2s, each.

The New Mistress.

yitness to the Deed.

The Tiger Lily.

The White Virgin.

Crown 8 ro, cloth, $3 s, 6 d$. each.

A Woman Worth Winning.

Cursed by a Fortuno.

The Case of Ailsa Gray.

Com modore Junk.

Black Blood.

Double Cunning.

A Fluttered Doyecote.

King of the Castle.

The Master of the Ceremonies.

The Story of Antony Grace.

The Man with a Shadow.

One Mald's Mischier.

Thls Man's Wife.

The Bag of Diamonds, and Three Blts of Paste.

Rumning Amok.

Crown 8vo, cloth, 6s, each.

Black Shadows.

The Cankerworm.

So Like a IVoman.

A Crimson Crime. Crown 8vo, cloth, 3s. 6d. ; picture cloth, flat back. 2s.

FICTION, a Catalogue of, with Descriptions and Reviews of nearly TWELVE HUXDRED NOVELS, will be sent free by CHATTO \& VINDCS upon application.

FIN = BEC. The Cupboard Papers. The Art of Liring and Dining. Post 8vo, cloth. 25. 6u.

FIREWORK - MAKING, The Complete Art of ; or, The Pyrotechnist's Ireasury. By Thosidy likNisit. With 267 Illustrations, Cr. 8vo, cloth, 3s. 6\%.
FITZGERALD (PERCY), by.

Wittlo Essays: Passages from the Letters of Charles LAMB. Post 8vo, cloth, 2s. 6 \%.

Fatal Zero. Crown Svo, cloth, 3s. Gi.; posl sro, ilitustrated boards, 25 .

Post Sro, illustrated bcards, 2s. each.

Bolla Donna. | Polly.

The Lady of Brantome.

Noyer Forgotten.

The Second Mrs. Tillotson.

Seventy-fire Brooke Street.

The Life of Laurence Sterno. With a Portrait. Crown 8vo, cloth, 6s.

FLA M M ARION (CAMILLE), Works by.

Popular nstronomy. Translated by f. ELLARD GORE, F.R.A.S. With Three Plates and 288 lllustraticns, A Nkw EnITION, will an Appendix giving the results of Recent Discoverics. Medium Svo, cloth, 10s. $6 \%$.

Thunder and cightning. Translated by WALTER MIOSTYN. Will lliustrations. Crown Ero, cloth, 6s. net.

FLETCHER'S (GILES, B.D.) Complete Poems: Christ's Victorie in Ilearcn, Victorie on Earth, Triumph over Deach; with Minor Pocms. Notes by Rev. A. B. Grosart. Cr. 8vo,cl, 3s. $6 d$.

FLORENCE PRESS BOOKS.For information as to this important Series, printed from a new type designed by HirBert P. HORNE, and now first cngraved and cast, see special Prospectus.

FORBES (Hon. Mrs. WALTER). -Dumb. Crown 8vo cleth. $3 s .6 d$.

FRANCILLON (R. E.), Novels by. Crown 8 ro, cloth, $3 s .6 d$. each; post Svo, illustrated boards, $2 s$, each.

One by Ono 1 A Feal Queen. A Dog and his Shadow.

Ropes of Sand. With Illustrations.

Post Svo, illustrated boards, 2s. each.

Queen Cophetua. | Olympla. Romances of the Lax.

King or Knaye?

Jack Doyle's Daughter. Crown 8vo, cloth, $3 s$. $6 d$.

FREDERIC (HAROLD), Novels by. Post 8vo, cloth. 3s. 6a. cach; illustrated boards, $2 s$. each.

Eeth's Brother's WIifo.

The Lawton Girl.

FRY'S (HERBERT) Royal Guide to the London Charities. lidited by Jorrs Lasis. Publislied Anmully. Crown 8vo, cloth, is. 6 t. 
GARDENING BOOKS. Post 8\%o, Is. each ; cloth, 15, 6d. each.

A Year's Work in Garcien and Greenhouse. By GeORGk GLEXNY.

Household Horticulture. I3y Tos and JANE JERROLD. lllustrated.

The Garden that Paid the Rent. By 'Iosi JERROLD.

Our Kitchen Garden. By TOM Jerrold * Post $8 \mathrm{v}^{\circ}$, cloth, is net.

Sir WIIllam Temple's Essay on Gardens; togetherwith other Cirolean Lissays on Gardens, Edited, with Jotes and introduction, by A, Formes SIEvE. KIX(3, F.S.A. With 6 Illustrations. Small $8 v 0$, cloth or boards, is. 6d. net ; quarter vellum, 25. $6 d$. net; ihree-quarter vellum, 55. net.

GAULOT (PAUL), Books by.

Tho Rod Shirts: A Tale of "The Terror. Translated by JOIN IDE VILLIERS. Crown 8 ro, cloth, with Fronlispiece by STANLEY WOOD, 35.61.; picture cloth, flat back, 25 .

Crow!s 8vo, cloth, 6s. each.

Loye and Loyers of the past. Translated by C. LAROCHE. M.A.

A Conspiracy under the Terror. Iranslated by C. LAROCHE, M.A. With 11lustrations and Fucsimiles,

GERARD (DOROTHEA).-A Queen of Curds and Cream, Crown svo, cloth. 3s. 64 .

GERMAN POPULAR STORIES. Collected by the Brothers GRIms and Translated by EDGAR TAYLOR. Wilh Intfoduction by JOHN RUSKIs, and 22 Steel Plates after GEORGE CRCIKSHANK, Square Svo, clotl gilt. 6s.

GIBBON (CHARLES), Novels by. Crown 8vo, cloth, 35. 6.t. each; post 8 vo, illustrated boards, 2s. each.

Robin Gray.

The dolden Shaft.

The Flower of the Foriest.

The Braes of Yarrow.

or High Degree,

Queen of the Meadow.

post 8vo, illustratcd boards, 25. cach.

The Dead Heart.

For Lack of Gold.

What Will the World Say?

For the Klng. I A Hard Knot.

In Pastures Green.

In Loye and $Y$ ar.

A Heart's Problem.

By Mead and Stream.

Fancy Free. | Loying a Dream,

In Honour Bound.

Heart's Delight. | Blood-Money.

G I B N E (SOMERVILLE). Sentenced I Crown 8vo, cloth. Is.6d.

GIBSON (L. S.), Novels by. Crown 8vo, cloth, 6s, each.

The Freemasons, | Burnt Splces.
GILBERT (WILLIAM).-James Duke, Costermonger, Post $8 v^{\circ}$, illus. trated boards, $2 s$.

GILBERT'S (W. S.) Original Plays. In 3 Series, post 8 ro, 2s. 6d. each.

The likST SERIES contains: The Wicked World - Pygmalion and Galatea Charily-The Princess-The Palace of Truth-Trlal by Jury-Iolanthe.

The SECOND SERIES conlains: Broken Hearts - Engaged - Sweethearts -Gretchen - Dan'l Druce-Tom Cobb - H.M.S. 'I'inafore'-The SorcererThe Pirates of Penzance.

The TuIRD SERIES contains: Comedy and Tragedy - Foggerty's Fairy - Kosewcrantz and Guildenstern-PatiencePrincess Ida-The Mikado-Ruddigore -The Yeomen of the Guard-The Gondoliers-The Mountebanks-Utopia.

Elght Original Comio Operas written by W. S. GileERT. Two series, demy 8vo, cloth, 25.6d. each.

The FIRST SERIES contains: The Sorcerer - H.M.S. 'Pinafore'- The Pirates of Penzance - Iolanthe - Patience - Princess Ida-The Mikado-Trial by Jury.

The SECOND SERIES contains: The Gondoliers-The Grand Duke-The Ycomen of the Guard-His Exceltency-Utopia, Limited-Ruddigore-The Mountebanks - Haste lo the Vedding.

The Gilbert and Sulliyan Birth. day Book: Quotations for Every Day in the Year. Compiled by $\Lambda$. WATSOS. Roval $16 \mathrm{mo}$, clnth. 2s. $6 \mathrm{~d}$.

GISSING (ALGERNON), Novels by. Crown 8 \%o, cloth, sill top. 6 s. cacts. A Secret of the North Sea.

hnitters in the Sun.

The XXealth of Mallerstang.

An Angel's Portion.

Ealiol Garth.

The Dreams of Simon Usher. Crown 8vo, cloth, 3s. $6 d$.

GLANVILLE (ERNEST), Novels by. Crown 8 vo, cloth, 3s. 6\%. eacls : post 8vo, lllustrated boards, 2s, each.

The Lost Heiress. With 2 Illustrations by HUME NISBET.

The Fossicker: A Romance of Mashonaland. 'Two lilusts, by Huse NiseEr.

A Fair Colonist. With lirentispiece.

The Golden Rock. With Frontispiece by STANLEY WOOOD, Cr. 8vo, cloth, 35. $6 l$.

Tales from the Yeld. With 12 lilustrations. Crown 8vo, cloth, 3s. 6d.

Max Thornton. With 8 llusirations by J. S, CROMIPTON, R.I. Large crown 8 vo. clolh, gilt edges, 5s. F

GLENNY (GEORGE).-A Year's Work in Garden and Greenhouse: Practical $\Lambda$ dvice as to Flower, Fruit, and Frame Garden. Post 8vo, 15.: cl.. 1s. $6 d$.

GODWIN (WILLIAM):- Lives of the Necromancers. Post $8 \mathrm{ro}, \mathrm{cl}, 25$. 
OOLDEN TREASURY

Thought, The: A Dictionary of Quotations from the Best Authors. By THEODORE TAYLOR. Cr. 8ro, cl., 3s. 6d.

GOODMAN (E. J.)-The Fate of Herbert IVayne. Cr. 8vo. cl.. 3s. 6l.

GORDON (SAMUEL). - The Ferry of Fate: a Tale of Russlan Jewry. Crown 8vo, cloth, 6s.

GORE (J. ELLARD, F.R.A.S.). - The Stellar Heavens: an Introduction to the Study of the Stars and Niebula. Crown sinn sinth, 2s. net. Crowir ave. Hert, wa. cach.

Studles in Astronomy. With 8 plates.

Astronomical Essays, Historical and Descriptive. With 6 plates.

GRACE (ALFRED A.).-Tales of a Dying Race. Cr. 8vo, cl., 3s. $6 d$.

GREEKS AND ROMANS, The LIfe of the, described from Antique Mlonuments. By ERxST GUHL and WV. KONER. Edited by Dr, F. HUEFFER. With 545 Illusts. Demy 8vo, cl., 7s. $6 d$.

GREEN (ANNA KATHARINE), Novels by. Crown 8 vo, cloth, 6s. each. The Millionalre Baby.

The Amethyst Box.

The Yoman in the Alcoye.

GREENWOOD (JAMES).-The Prisoner in the Dock. Crown 8vo, cloth, 3s. 6d.

GREY (Sir GEORGE). - The Romance of a Proconsul. By James MILNE. Crown 8vo, buckram, $6 s$.

GRIFFITH (CECIL).-Corinthia Marazion. Crown 8vo, cloth, $3 s$. $6 x$.

GRIFFITHS (Major A.).-No. 99, and Blue Blood. Crown 8vo. ctoth, 2s.

GUNTER (A. CLAVERING).-A Florida Enchantment. Crown 8vo, cloth, 3.s. 6.\%.

GUTTENBERG (VIOLET), Novels by. Crown 8 ro, cloth, 6s. each. Neither Jey nor Greek.

The Power of the Palmist.

- OYP. - CLOCLO. Translated by NORA M. STATHAM. Cr. $8 \mathrm{vo}$, cl., $35.6 d$.

HABBERTON (JOHN).-Helen's Bables. With Coloured Frontispiece and to Jifustration by Eva Roos. Fcap. 4 to. cloth. $6 s$.

HAIR, The: Its Treatment in Health, Weakness, and Dlscase. Transiated from the German of Dr. J. Pisces. Crown 8vo, Is.; cloth, is. $6 d$.
HAKE (Dr. T. GORDON), Poems

by. Crown $8{ }^{\circ}$, cloth, 6s, each.

New symbols.

Legends of the Morrow.

The Serpent Play.

Malden Ecstasy. Small 4 to, cloth, 8 s.

HALL. (Mrs. S. C.).-Sketches of Irlsh Character. With Illustrations on Steel and Wood by CRUIKSHANK, M ACLISE, GILBERT, and HARVEY. Demy 8 vo, cloth, 7 s. $6 d$.

\section{HALL (OWEN), Novels by.}

The Track of a Storm. Crown 8vo, picture cloth, flat back, $2 s$.

Jetsam. Crown 8vo, ctoth, 3s. $6 d$.

Eureka.

Crown 8vo, cloth, 6s, each.

H A L L I D A Y (A N D R E W).Every-day Papers. Post $\delta$ vo, iltustrated boards, $2 s$.

HAMILTON (COSMO), Stories by.

The Glamour of the Impossible; and Through a Keyhole. Crown 8 vo, cloth, 3s. $6 d$.

Nature's Yagabond, \&c. Crown 8vo, cloth, $6 s$.

\section{HANDWRITING, The Philo-} sophy of. With over 100 Facsimiles. By LoN Felix de Salamasca, Post 8vo, half-cloth, 2s. $6 d$.

HARDY (IZA DUFFUS), Novels by. Crown 8 vo, cloth, $6 s$, each.

The Lesser Exil.

Man, Woman, and Fate.

A Butterfly.

HARDY (THOMAS). - Under the Greenwood Tree. Post 8vo, cloth, 3s. 6d.; itlustrated boards, 2s, ; cloth limp, 2s. $6 d$. Also the FiNe PAPER EDITION, pott $8 \mathrm{vo}$, cloth, gilt top, 2s. net : leather, gilt edges, 38. net ; and the CHEAP EDITION, medium 8 vo, $6 d$.

HARKINS (E. F.).-The Schemers. Crown 8 vo, cloth, $6 s$.

HARRIS (JOEL CHANDLER), Books by.

Uncle Remus. With 9 Coloured and 50 other Illustrations by J. A. SHEPHERD. Pott $8 \mathrm{vo}$, cloth gitt, $6 s$.

Nights with Uncle Remus. With 8 Coloured and 50 other Illustrations by J. A. SHEPHERD, Imperial r6mo, cloth:, $6 s$. 
HARTE'S (BRET) Collected Works. LIBRARY EDITION, in Ten Volumes, crown 8 vo, cloth, 6s. each.

Vol. I. Complete POETICAL aND DRANATIC WORKS. With Porl.

II. THE Li'CK OF ROARING CAMPBOHEMIAN PAPERS-AMERICAN LEGENDS.

III. TALES OF TII ARgonautsEASTERN SKETCHES,

IV. GABRIEL CONROY.

V. STORIES - CONDENSED NOVELS,

VI. TALES OF THE PACIFIC SLOPE.

VII. TAlesof the Pacific SlOPE-II. With Portrait by JohN PETTIE.

VIII. TALES OF PINE AND CYPRESS.

1X. BUCKEYE AND CIAPPAKRL.

X. TAles of Traik aNd TOWN.

Bret Harte's Cholce Works in Prose and Verse. With Portrait and 40 Illustrations, Crown 8vo, cloth, 3s. 6et.

Bret Harte's Poetical Works, including Sosie Later Verses, Cruin 8 vo, buckram, $4 s .6 d$.

In a Hollow of the Hills. Crown $8 \mathrm{vo}$, picture cloth, flat back, $2 s$.

Condensed Noyels. ( $T$ wo Series i.s One Volume.) Pott 8vo, cloth, gilt top, $2 s$. net; lealher, gill edges, $3 s$. net.

Crown 8vo, cloth, 6s. each.

On the Old Trall.

Under the Redwoods.

From Bandhill to PIne.

Storles in Light and Shadow.

Mr. Jack Hamlin's Mediation.

Tront's Trust.

Crown $85^{\circ}$, cloth, $3 s .6 \%$. each : post $8 v 0$, illustraled boards, 25 . each.

Gabriel Conroy.

A Yalf of the Pialns. With 60 Illus trations by STANLEY L. WOOD.

A Ward of the Golden Oate. With 59 Illustrations by STANLEY L. WOOD.

Crown $8 v 0$, cloth, $3 s .6 d$ each.

Susy. Will 2 Illusts, by J. A. Christre.

The Bell-Ringer of Angel's, \&c. With 39 lliusts, by DCDLEY HARDY, \&c.

Clarence: A Story of the American War. With 8 Illustrations by A. JULE GoODMAx.

Barker's Luck. \&c. With 39 Illustrations by A. ForeSTIER, PAUL HARDY, \&C.

Deyll's Ford, \&c. With Frontisplece.

The Crusade of the 'Excelsior.' With Frontis, by J. BERAARD PARTRIDGE

Three Partners; or, The BIg Strike on Heavy Tree HIII. With 8 lllustrations by $\}$. Gurich.

Tales of Trall and Town. With rrontispiece by G. P. JACOMB-HOOD.

Condensed Noyels. New Series.

Crown 8vo, cloth, 3s. 6d. each; picture cloth, flat back, 2s. each.

A Sappho of Green Sprlngs.

Colonel Starbottle's Cllent.

A Protegéo of Jack Hamiln's. With numerous lllustrations.

Bally Dows, \&c. With 47 Ilustrations by W. D. Atstoxd and others.
HARTE (BRET)-continued.

Post 8vo, jllustrated boards, 2s. each.

The Luck of Roaring Camp, and Sensation Noyels Condensed.

(Also in picture cloth at same price.)

An Helress of Red Dog.

The Luck of Roaring Camp. Callfornian Btorles.

Post $8 v^{\circ}$, illus. bds, 2s. each; cloth, 25. 6i, each. Fllp. I Phyllis of the Sierras.

Maruja. Crown 8vo, cluth, 35.6 . ; pos! $8 v 0$, picture boards, 2 s. . cloth limp, $2 s .6 d$.

HAWEIS (MrS. H. R.), Books by. The Art of Beauty. Wilh Coloured Frontis. and of lllusts. Sq. $8 \mathrm{r}$, cloth, $6 \mathrm{~s}$.

The Art of Decoration. With Coloured Frontispiece and 74 Illustrations. Square 8vo, cloth, 6 s.

The Art of Dress. With 32 Illustrations. Post $8 v 0,1 s$. : cloth, Is. $6 d$.

Chaucer for Schools. With Frontispiece. Demy 8vo, cloth, 2s. $6 d$.

Chaucer for Chlldren. With 8 Coloured Plates and 30 Woodcuts. Crown 4 to, cloth, 3s. $6 d$.

HAWEIS (Rev. H. R.),-American Humorists: WASHISGTON IRVING, OlIVER WeXdell HOLMES, JANES RUSSEll lowell, ARteyiUs IVARD, MARK TWAIN, and BRET HARTE. Crown 8vo, cloth, 6 s.

HA W T ORNE (J ULIAN), Novels by. Crown 8vo. cloth, 3s. 6d. cach; post 8 vo.illustrated boards, 25 , eacil. Garth. | Ellice Quentin.

Fortune's Fool. I Duse. Four Illusts. Beatrix Randolph. With Four Illus!s. D. Polndexter's Disappearanoo. The Spectre of the Camera.

Crown $8 \% 0$, cioth. 3s, 6d. each.

Sebastian 8 trome.

Loye-or a Name.

MIss Cadogna. rost $\gamma$ vo, illustrated boards, 2s.

HEALY (CHRIS), Books by. Crown 8vo. cloth. 6s. each.

Confessions of a Journalist.

Heirs of Reuben.

Mara.

The Endless Heritage. Crown 8ro, cloth, 3s, 6d.

HELPS (Sir ARTHUR), Books by. Post 8 vo, cloth, 25, 6d. each.

Anfmals and their Masters. Soclal Pressuro.

Iyan de Biron. Crown 8vo, cloth 35. 6 d.: post 8 vo, illustrated boards, 25.

HENTY (G. A.), Novels by.

Rujub, the Juggler. Deny 8 vo, cloth, with 8 Illustrations by S. L. Kood. 5 s, : post 8vo, clolh, 3s. 6d.; illust, boards, $2 s$.

Crown 8 yo, cloth, 3s, 6ut each.

The Queen's Cup.

Dorothy's Double.

Colonel Thorndyko's Secret. 
HENDERSON (ISAAC).-Agatha Page. Crown 8vo, cloth, 3s.6d.

HERMAN (HENRY). - A Leading Lady. Post $8 \mathrm{~s} 0$, cluth, 2s. 6r?.

HILL (HEADON). - Zambra the Detectlve. Crown 8\%o, cloth, 3s. 6i.: picture cloth, flat back, 25.

IILL (JOHN), Works by.

Treason-Felony. Post Sro, idustrated boards, $2 s$.

The Common Anoestor. Crown Sro, clolh, 3s. 6.l.

HINKSON (H. A.), Novels by. Crown Sso, cloth, 6s. each.

Ran Fitzgerald. | Silk and Steol.

HOEY (MrS. CASHEL). - The Lover's Creed. Crontin, Sto, cloth, $3 s .6$. : p post Sro, illustrated boards, $2 s$.

HOFFMANN (PROFESSOR).KIng Koko. A Jagic Story. With 25 Illustrations. Crown $8 r^{\circ}$,cloth, Is. net

HOLIDAY, Where to go for a. By E. P. SHOLI, Sir H. NAXWELl, JOH. VIATSON, JANE BARLOW, MARY LOVET Cambrox, Justix H. MCCarthy, PaUl LANGE, J. W'. GRAHAM, J. H. SALTER, PHobe Alle.N, S. J. BECKETT, L. RIVERS VIxk, and C, F. Gordon Cumms. Crown 8 vo, cloth, is. $6 \%$.

HOLMES (OLIVER WENDELL), Books by.

The A tocrat of the BreakfastTable. IJJustratcd by J. GORDON 'THONisos. Post 8vo, clolh limp, 2s. 6d. Also the Frie PAPER EnTrion, pott $80^{\circ}$, cloth, gilt top, 2s, net.; leather, gilt edges 3s. net. A nother Edition, post $8 \mathrm{vo}$, cloth,2s.

The $F u$ tocrat of the BreakfastTable and The Professor at the Breakfast-Table. In one vol., post svo, half-cloth, 2 s.

HOOD'S (THOMAS) Choice Works in Prose and Verse. Witt] Life of the Author, Portrait, and 200 Illustralions. Crown 8vo, cloth, 3s. $6 d$.

HOOK'S (THEODORE) Choice Humorous Works; including his Ludicrous Adventures, Bons Mots, Puns, Hoaxes. With Life and Frontispiece. Crown 8vo, cloth, $3 s .6 d$.

HOPKINS (TIGiHE), Novels by.

For Freedom. Crown $8 \mathrm{~s}^{\circ}$, cloth, $6 s$. Crown 8vo, cloth, $3 s, 6 d$. each.

'Tyixt Love and Duty.

The Incomplete Adyenturer.

The Nugents of Carriconna.

Nell Haffenden. Itilh 8 llinstrations.

HORNE (R. HENGIST).-Orion. with Portrail. Crown svo, cloth, $7 s$.
HORNIMAN (ROY), Novels by

Crown $8 v 0$, cloth, 6s. each.

Bellamy the Magnificent.

Lord Cammarleigh's Secret.

Israel Rank. Crown Svo, cloth, 3s. 6d.

HORNUNG (E. W.), Novels by.

The Shadow of the Rope. Crown Sro, cloth, 3s. Gd.

Crown 8vo, cloth, os, each.

Stingaree. | $\bar{A}$ Thief in the Night

HUGO (VICTOR). - The Outlaw of Iceland. Translated by Sir GiLeErT CAMPBELL. Crown Svo, cloth, 3s. 6el.

HUME (FERGUS), Novels by.

Tho Lady From Nowhere. Cr. 8vo, cloth, 3s. 6d.: picture cloth, flat back, $2 s$.

The Millonaire Mystery. Crown $8 \% 0$. cloth, 3s. 6 ?

The Wheeling Light. Crown 3ro, clolh, silt top. os.

HUNGERFORD (Mrs.), Novels by. Crown $8 v 0$, cloth, 3s. 6d. each : post $8 v 0$, illustrated boards, 2s. euch: cloth linup, 2s. $6 i$. each.

The Professor's Experiment.

Nora Creina.

Lady Yerner's Flight.

Lady Patty. | Peter's YXifo.

The Red-House Mystery.

An Unsatisfactory Loxcr.

April's Laay.

A Maiden All Forlorn.

The Three Graces.

A Mental Struǵle.

Maryel. $\quad$ A Modern Circe.

In Durance Ylle.

Crown svo, cloth, 3s. 6d, each.

Fn Fnxious Moment.

A Point of Conscience.

The Coming of Chloe. | Loyice.

HUNT'S (LEIGH) Essays: A Tale for a Chimney Corner, \&c. Ed. by E. Ollier. Post 8 vo, hali-cl. $2 s$.

HUNT (MrS. ALFRED), Novels by. Crown 8 vo, cloth, 3s. 6d. each; post 8 vo, illustrated boards, $2 s$, each.

The Leaden Casket.

Self-Condemned.

That Other Person.

Mrs. Jullet. Crown 8vo, cloth, 35. $6 d$.

HUTCHINSON (W. M.) - Hints on Colt-Breaking. With 25 Illustraltions. Crown $8 v^{\circ}$, cloth, 3s. 6d.

HYATT (A. H.).-The Charm of London: An Anthology. Pott 8vo, cloth, gilt top, 2s. net ; lcather, gilt ediges, 3 s. net.

INDOOR PAUPERS. BY ONE OF Try.r. Crown Sro, 1s.; cloth, Is. fid. 
INMAN (HERBERT) and HARTLEY ASPDEN. - The Tear of Kalee. Crown 8ro, cloth, gilt top, 6 s.

INNKEEPER'S HANDBOOK (The) and Licensed Victualler's Manual. By J. TRElOR-DNIIES. Crown 8vo, cloth, 25 .

IRISH WIT AND HUMOUR, Songs of. Edited by A. PERcelal GRAves. Post 8vo, cloth. 2s. 6t?.

JAMES (C. T. C. ) - A Romance of the Queen's Hounds. Post 8 ro, cloth limp, 1s.6i.

JAMES (G. W.). - Scraggles: The Story of a Sparrow. With $\theta$ Illustrations. Posi 8 vo, cloth, 25. 6d.

JAMESON (WILLIA M). - My Dead Self. Post 8vo, cloth, $2 s .6 d$.

JAPP (Dr. A. H.)-Dramatic Plctures. Crown 8vo, cloth, 5 .

JEFFERIES (RICHARD), by.

The Open A Ir. Post $8 v^{\circ}$, cloth, 2s. 6.i. LARGE TYIE, FINE PAPER EDITION, poti 8 vo, cloth, gilt top, $2 s$. net ; leather, gilt edges, $3 s$. net. Also in prefaration, a New Edition, with I2 Illustrations in Colours by RuTH DoLlMAx. Square $8 \mathrm{vo}$, cloth, $5 \mathrm{~s}$. net.

The Life of the Fields. Past $8 \mathrm{so}^{\circ}$ cloth, 2s.6d. ; LARGE TYYK, FINE, PAPER EDIrION, pott $8 \% 0$, cloth, gilt top, 2s. net leather, gilt edges, 3s. net. Also in $\mathrm{fl}^{\mathrm{e}}$ faration, a Jew Ldition, with 12 Illustrations in Colours by M. H.CLARKE. Square 8 ro, cloth. $5 s$, net.

Nature near London. Crown 8vo, buckram, 6s. : post 8 vo, cl., 2s. 6d. - LARGE TIPE, FIXE PAPER EUITION, pott $8 \mathrm{vo}, \mathrm{cl}$. gilt top, 25 , net ; leather. gilt edges, 3s.net.

The Pocket Richard Jefferies: being Passages chosen from the Nature Writings of JEFFEIRIES by ALFRED $H$. HYATT, I6mo, cloth, gilt top, $2 s$. net.; leather, gilt top. 3.s. net.

The Eulogy of Rlchard Jefferies. By Sir IVALTRR BEsaNT. Cr. 8vo, cl.6s.

JENNINGS (H. J.).-Curiosities of Criticism. Post 8 vo, clotb, 2s. 6 d.

JEROME (JEROME K.).-Stageland. With 6 \& IMustrations by J. BERNARD Partridge. Fcap. 4 to, 1 s.

JERROLD \$(DOUGLAS). - The Barber's Chalr; and The Hedgehog Letters. Host 8 vo, half-cloth. 2 s.

JERROLD (TOM), Works by. Post 8vo, 1s. each ; cloth, Is. $6 d$. each.

The Garden that Paid the Rent. fousehold Horticulture.

Our Kitchen Garden: The Plants We Grow, and Ilow lle Crob l'hem. Post s:o, cluth, Is. net.
JOHNSTON (R.).-The Peril of an Empire. Crown 8 ro, clotb, 65 .

JONES (WILLIAM, F.S.A.), Books by. Cr. 8vo, cloth, 3s.6r. each.

Finger-Ring Lore: Historical, Legendary, and Anecdotat. With wumerous Illustrations.

Crowns and Coronations. With 91 Illustrations.

JONSON'S (BEN) Works. With Notes and Biograplical Memoir by WILLIAM GIFFORD. Edited by Colonel CcNsisghan, Three Vols., crown Syo, cloth, 3s. 6d. each.

JOSEPHUS, The complete Works of. Translated by WiLLIAa Whistox, Containing "The Antiquities of the Jews,' and 'The Wars of the Jex's.' Vith 52 lliustrations and Maps. Two Vols., demy 8 ro, balf-cloth, I25. $6 d$.

KEATING (JOSEPH).-Maurice. Crown 8vo, eloth, 65 .

KEMPT (ROBERT).-Pencil and Palette : Chapters on Art and Artists. Post 8vo, cloth, 25. $6 d$.

KERSHAW (MARK).-Colonial Facts and Fictions: Humorous Sketches. Post $8 v^{\circ}$, illustrated boards, 2s. ; cloth, $2 s .6 d$.

KING (LEONARD W., M.A.).A History of Babylonia and Assyria from the Earliest Times until the Perslan Canquest. With Maps, llans, and Illustrations after all the principal Nonuments of the Period. In 3 volumes, royal 8 vo, buckram. Each volume separately, $18 s$, net ; or per set of 3 volumes, if subscribed for before the issue of Yol. In $f 2125.6 d$, net.

Vol, 1,- A History of Sumer and Akkad: An account of the Primitive Inhabitants of Babylonia from the Earliest Times to B.C, 2000.

[Spring, 1908.

11. A History of Babylon from the First Dynasty, about B.C. 2000, until the Conquest by Cyrus, 13.C. 539 .

iPrefaring.

I11. - A History of Assyria from the Eariiest Period until the Fall of Ninereh before the Medcs, B.C. 606.

[Preparing.

KING (R. ASHE), Novels by. Post 8ro, illustrated boards. 25.

"The Wearing of the Green." Passion's Slaye. Bell Barry.

A Drayn Game. Crown 8vo, cloth. 3s. 6t.; post 8\%o, illustrated boards, $2 s$. 
KING'S CLASSICS (The). General Fditor, Professor 1. Gollaxc7. Litt.D. Printed on laid paper, $36 \mathrm{mo}$ each with Frontispiece, gilt top. Quar. ter bound grey boards or red cloth. 3s. 6u. net each; quarter vellum, cloth sides, 2s. 6d. net each; three-quarter rellum, 53, net each.

Volumes now in course of fublicalion:

35. Wine, Women, and Song: Mediacval Lalln Students "Songs. Trans lated into English, with an Introduction, by JOHN ADDINGTON SYMONDS, IVith Frontispiece.

36, 37. Georfe Pettle's Petlte Pal laco of Pettie his pleasure. 2 vols.

38. Yalpole's Castle of Otranto. By Sir IVALTER ScolT. IVilh Introduction and Preface by Miss Spergron

39. The Royal Poets of England Original Poems by English Kings and otber Royal and Noble Persons, collected and edited by W. BALEV KEMPLING.

40. SIr Thomas More's Utopla. Edited by IROBRRT STEELF, F.S.A.

41.tChaucer's Legend of Good Women. In Wodern English, with Notes and Introduction by Professor IV. IV. SkEAT.

42. Syift's Battle of the Books. Edited, with Notes and Introduction, by A. GuthiElgh.

43. Sir William Temple's Essay on Gardens, with other Carolean Essays on Cardens. Edited, with Notes and Introduction, by A. Forbes SIETEKING, F.S.A.

44. The Four Last Things, by Sir THOMAS MORE: together with $A$ Spiritual Consolation and other Treatlses, by JOHN FisHer, Bishop of Rochestcr. Edited by DANiEl. O'CONNOR.

45. The Song of Roland. Translated irom the old French by Mrs. CROSLAND. With Introduction by Prof. BRANDIN.

46. Dante's Yita Nuoya. The Italian text, with DANTE G, ROSSETrI's translation on the opposite page. With Introduction and Notes by Prof. $\mathrm{H}$. OELSNER.

47.tChaucer's Prologue and Minor Poems. In modern English, with Notes and Introduction by Prof W. WV. SkFAT.

\section{Chaucer's Parllament} Birds and House of Fame or medern English, with Notes and Intro duction by Prof. WV. IV. SkEAT.

49. Mra. Gaskell's Cranford. With Introduction by R. BRIsLEY JOHxsON,

50. Pearl. An English Poem of the Fourteenth Century. Edited, with a Modern Rendering and an Introduction,
KING'S CLASSICS (The)-continued.

51, 52. King's Letters. Volumes 111. and IV. Newly ediled from the nrigina!s bY ROBERT STEKLE. F.S.A.

53. The Engllsh Correspondence of Saint Boniface. Translated and edited, with an Introductory Sketch of the Lite of St. Boniface, by E. J. KYLIE, M.A.

54, 55. The Essays of Ella. Edited, with Notes. Introduction, $\& c_{*}$, by THOMAS SEcCOMBE, M. A.

Summary List of other Volumes in the Serics, for details of which sce Siccial Prospecaus.

1. The Love of Books (The Philobililion).

*. Six Dramas of Calderon (Filzierald s Trabslstion). (Double vol.i

3. Chronicle of Jocelin of Brakelond.

4. The Life of sir Thomag More.

5. Wikon Basilike.

6. Kings' Jetters : Alfred to the coming of the Tudors.

i. Kings' Letters: From the Tudors to the Love Letters of Henry VIII.

8. +Chaucer's Knigbt's Taie (Prof. SKFAT).

9. +Chaucer's Man of Law's T'ale (Pruf.Skgat).

1\%. +Chancer's Prioress's Tale (Pruf. Skinat).

11. The Romance of Fulke Fitzwarine.

12. Tlie Story of Cuyjd and Psjclue.

13. Evelsn's cife of Mrargaret Godolplin.

I4. Rnrly Lires of Dante.

ij. The Falstaff Leiters.

i6. Polonius. By EDward FitzGerald.

i7. Mediaval Lore.

18. The Vision of Piers the Plowiran (Prof. SKEAT).

19 The (iuli's Hornbook.

:0. *Tlue Nun's Jiule, or Ancren Riwle. (Double vol.).

21. The Memoirs of Rohert Cary, Earl of Mon. nouth.

22. Early lives of Char lemagne.

23. Cicero's 'Friendshir,' 'Old Age, and "Scipio' Drean."

it *Wordsworth's Prelude. (Donble val.)

95. The Defence of Guenevare.

\%6. 2E. Bromping's Men and Wumen.

$2 x$. Poe's Poens.

39. Slizkespeare's Sonvets.

30. fienrge Eliot's Silns Marner.

31. Goldsmith's vicar of Wakefield.

32. Charles Rezde's Pes Woftington.

33. The Household of Sir Thomas More.

31. Sapplo: One Hundred Lyrlcs. By Buiss CAKYA.

- Numbers 2. 20, snd 24 are Double Volumes and Double Price.

+ Tbe Clinucer Vols. may also be had in stift paper covers at 18 . eavil.

KING'S

(The).

The Mirrour of Yertue in Worldly Greatnes, or The Life of BIn Thomas More, Knight. By his son-in-law, WILLIAM ROPLR. IOs. $6 d$. net. (Seven copies of this volume alone remain, and are not to be sold apart from sets.)

Eikon Basillke, the Portraicture of His Sacred Majestie ln $\mathrm{hls}$ Bolltudes and Sufferings. Edited by EDWARD ALMACK, F.S.A. fI is. net.

Shakespeare's Oyid, belng Arthur Golding's Translation of the Metamorphoses. Fdited by VV. H. D. ROUSE, Lilt.D. fit I1s. 6h, atet. 
KING'S LIBRARY

(The)-continued.

The Percy Folio of Old English Ballads and Romances. Edited by the GENERAL EDITOK. In four volumes at $f 445$. the set. (Volunies I. and II. issued; III. at Press; $1 \mathrm{~V}$. in Preparation.)

- Not8.-Seven comflete sets of the above folios temain for sale. Price, fer set, $\$ 717$ s. 6 d $n i t$.

\section{KING'S LIBRARY QUARTOS} (The).

The Alchemist. By BEN Josson. Edited by 11. C. HART, 5s. net ; Japarese vellum, fil is. net.

The Gull's Hornbook. By THOMAS DEKKER. Edited by K. B. MCKERROW 5. net : Japanese vellum, Jos, 6d. net.

The Begfar's Opera. By JoH. Gav. Ediled by HaMiltos MACLKOD. 5 s. net : Japanese vellum, 10s. $\%$. net.

KIPLING PRIMER (A). Including Biographical and Critical Chapters. an Index to Mr. Kipling's principal Writings, and Bibliographies. By F. L Kxowles, With Two Portrails. Crown 8 vo, cloth, 3s. 6d.

KN IGHT (WILLIA M a nd EDWARD : - The Patient's Vade Mecum : How to Get Most Benefit from Medical Advice. Crown 8*o. cloth, is. 6 d.

LAMB'S (CHARLES) Complete Works in Prose and Verse, including - Poetry for Children ' and 'Prince Dorus.' Edited by R. H. SIIEPHERD, With 2 Portraits and Facsimile of the " Essay on Roast Pig." Crown 8vo (both Series), cloth, 3s. 6.d.

The Essays of Ella (both Series). Post Sro, halt-cloth, 2s. -Also the FINE PAPER EDitios, polt $8 v 0$, cloth, gilt top, $2 s$, net leather, silt edges, $3 s$. net.

Little Essays: Sketches and Characters by CHARLES LAMB, selected from his 1.etters by Percy Fitzgerald. Posi $8 \mathrm{vo}$, cloth, 2s. $6 d$.

Tho Dramatic Essays of Charles Lamb. With lntroduction and Notes by BRANDER MaTrHews, and steel-plate Portrait. Feap. 8vo, hatf-cloth, 2s. 6d:

LAMBERT (GEORGE). - The President of Boravla. Crown 8 vo. cloth, 3s. $6 d$.

LANDOR (WALTER SAVAGE). - Citation and Examination William Shakespeare, \&c., befors Sir Thomas Lucy: toucbing Deer-stealing soth Septetmber. 1582 : and $A$ Confer ence of Master Edmund Spenser with the Earl of Essex, touch ing the stite of Ireland, 1595. Fcap, Sm. hals.Roxburghe, 2s, 6\%t.
LANE (EDWARD IVILLIAM). -The Thousand and One Nlghts, commonly cailed in England The Arablan NIghts' Entertainments. Translated from the Arabic and jllustrated by many hundred Engras:ings from Desigus by HARVEY. Edlted by E.S. POOLE. With Preface by Stanley LANE-POOI.E. 3 Vols., 8m, cl., 22s. $6 d$.

LARWOOD (JACOB), Books by. Anecdotes of the Clergy. Post $8 \mathrm{vo}$, hall-cloth, $2 s$.

Theatrical Anecdotes. Posl $8 \mathrm{ro}$ cloth, 2s. 6 \%

Humour of the Law. Post 8vo. cl., $2 s$.

LEES (D. NEVILE).-Tuscan Feasts and Tuscan Frlends. With 12 lilustrations. Large crown 8 vo, cloth, 5s. net.

LEHMANN (R. C.). - Harry Fludyer at Cambridge, and Conversational Hints for Young Shooters. Cruwn 8vo, is.: cloth. 1s. 6d.

LEIGH (HENRY S.).-Carols of Cockayne. Crown 8vo, buckram, 5s.

LELAND (C. G.).-A Manual of Mending and Repairing. With Diagrams. Crown 8vo, cloth. 5 s.

LEPELLETIER (EDMOND). Madame Sans-Géne. Translated by JOHN DE VILliers. Post $8 \mathrm{vo}$, cloth, 3s. 6d.; illustrated boards. 2s. ; POPCLAR EDition, medium 8 ro, $6 d$.

LESPINASSE, JULIE DE. By the Marquis DE SÉGle. Authorised English Version, with a Portrait. Demy $8 \mathrm{vo}$, cloth. 7s. Gi. net.

LEYS (JOHN K.), Novels by.

The Lindsays. Post $8 \% 0$, illust, bds., $2 s$. A Sore Temptation. Cr. $8 \mathrm{vo}, \mathrm{cl} .6 \mathrm{~s}$.

LILBURN (ADAM). - A Tragedy in Marble. Crown 8vo, cloth, 3s.6 6 .

LINDSAY (HARRY), Novels by. Crown $8 v 0$, cloth. 3s. 6d. each.

Rhoda Roberts. | The Jacoblte.

Crown 8vo. cloth, 6s. each.

Judah Pyecroft, Puritan.

The Story of Leah.

LORIMER (NORMA).-The Pagan Woman. Crowin 8vo, cloth, 6r.

LUCAS (E. V.), Books by. A Book of Yerses for Children. With Coloured Title-page. Crown 8vo, cloth, 6s.

Three Hundred Games and Pastlmes. Ly E. V, LtCAS and EIIZABETIt Licas. Pott 4 to, cloth, $6 s$, net.

LUCY (HENRY W.).-Gideon Fleyce. Crown 8vo, cloth, 35. 6d.; post $8 r o$, ilfustrated boards, $2 s$. 
LINTON (E. LYNN), Works by. An Octaxe of Frionds. Crewn 8vo, cloth. $3 s .6 d$.

Crown 8vo, cloth, 3s. 6d. cach ; post 8vo, illustrated boards, $2 s$. each.

Patricia Kembali. Ione.

The A tonement of Leam Dundas. The Worid Yell Lost. 12 Illusts.

The One Too Many.

Under whlch Lord? Wilh 12 Illusts.

'Iny Loye.' I Sowing tho Wind.

Paston Carew. I Dulcio Eyerton.

With a Silken Thread.

The Rebel of the Fanily.

Post 8*0, cloth, 2s. 6d, each.

Witch Stories.

Ourselyes: Essays on Women.

Sowing the Wind. CHEAP EDITON, post $8 v^{\circ}$, cloth. 15 . net.

Patricia Kemball. Popclar EdiJJON, medium sin, fid.

MACAULAY (LORD).-The this. tory of England. LARGe TrPe, IiNE Paper Edition, in 5 vols. pott $8 \mathrm{ro}^{\circ}$ cloth, gilt top, 2s. net per vol.; leather. gilt edges, 3s, net per vol.

M A C O L L (H U G H).-Mr. Stranger's Sealed Packet. Post 8 so, illustrated boirds $2 . s$.

McCARTHY (JUSTIN), Books by.

The Reign of Queen Anne. Two Vols.. demy 8vo, cloth, 12s. each.

A History of the Four Georges and of William the Fourth. Four vols., demy $8 v 0$, cloth, I2s. each.

A History of Our Owr Times from the Accession of Queen Victoria to the General Election of 1880. LIBRARY EDITION, Four Vols., demy $8 \mathrm{vo}$, eloth, 12s. each.-Also the POPULaR EDIrIoN. in Four Vols., crown 8vo, cloth, 6s. each. -And the JUBILEE EDITION, with an Appendix of Events to the end of 1886 , in 2 Vols., demy $8 \% 0$, cloth, $7 s .6 d$. each.

A History of Our Oxy Times, Vol.V., from i 880 to the Diamond Jubilee Demy 8vo, cloth, I2s.: crown Svo, cloth $6 s$.

A History of Our Own Times, Vols. VI. and VIL.. from 1897 to Accession of Edward VII. 2 Vols., demy 8vo, cl.. $24 . s$.

A Short History of Our Oxn Times, from the Accession of Qiteen Victoria to the Accession of King Edward VII. . NEW EDITION, revised and cnlarged Crown 8vo, cloth gill top, 6s.-Also (shortly) the Popular Esirion, enlarged, post 8vo, clolb, 2s. $5 d$.; and the CIIEAP EDITION (to the year I880) medium 8 vo, $6 d$.

Large TyPe, Fine PAPER Editions.

Polt $8 \mathrm{vo}$, cloth, gilt top, $2 s$. net per vol.; leather, gilt edges, $3 s$. net per vol.

The Reign of Queen Anno, in I Vol.

A History of the Four Georges and of William IY., in 2 vols.

A History of Our Own Times from Accession of $Q$. Victoria to 1897 , in 3 Vols.
McCARTHY (JUSTIN)-conimued.

Crown 8vo, cloth, 3s. 6d. cach ; post 8vo, pict. boards, 2s. each; cloth limp, 2s, 6d.each. The Waterdalo Neighbours My Enemy's Daughter.

A Fair Saxon. Linley Rochiord. DearLady Disdain. | The Dictator. Miss Misanthrope. With 12 Illusts.

Donna Quixote. With I 2 Illustrations. The Colmet of a Season.

Mald of Athens. WVill 12 Iltustrations. Camiola.

Red Diamonds. I The Riddle Ring. Crown sro, cloth, 3s. 6d. each.

The Threo Disgraces. | Mononia.

'The Right Honourable.' By Justis MICCAKIIY and MIRS. CAMIBELL PRAED. Crown 8vo, cloth. $6 s$.

McCARTHY (J. H.), Works by.

The French Reyolution. (Constituent Assembly, I789-9r.) four Vols., demy 8vo, cloth, 12s. each.

An outline of the History of Ireland. Crown 8vo, is. ; cloth, 1.s. $6 d$.

Ireland Since the Union-17981886. Crown 8vo, clolth, $6 s$.

Hafizin London. $8 v^{\circ}$, fold cloth. $3 s .6 d$.

Our Sensation Novel. Crown 8vo, Is. ; cloth, is. $6 d$.

Doom: An Atlantic Episode. Crown 8vo, Is. Dolly: A Sketch. Crown 8vo, is.

Lily Lass. Crown 8vo. ir, : cloth, is. 6d.

A London Legend. Cr. 8vo, cloth. 3s. $6 d$. MACDONALD (Dr. GEORGE), Books by.

Works of Fancy and Imagination Ten Vols., I 6 mo, cloth, giit, in case, $21 s$. ; or separately, Grolier cloth, $2 s .6 d$. each. Also a NEW Issue in $16 \mathrm{mo}$, eloth, gilt top, 2s. net per Vol.; leather, gilt top, 3 s. net per Vol.

Vol. I. VIITHIN AND IVITHOUT - THE HIDDEN LIFE.

"

II. THE DISCIPLE - THE GOSPEL WONEN-BOOI: OF SONNETSOrgan SONGS.

n III. VIOLIN SONGS-SONGS OF THE DAYS AND NIGHTS-A BOOK OF DREAMIS-ROADSIDE POEMS -POLMS FOR ChildreN.

IV. Parables - BalladS - Scotcil

V. \& VI. Phantastes. [SONGS,

VII. TIE POR'TENT.

VIII. The light Princess - Tue GIaNT'S HearT-SHadows.

" IX. Cross Purposes-Golden Key CARASOYN-LITTLEDAYLJGHT.

n X. THE CRUEL PAINTER-THE WOW O'RIVVEN-THE CASTLE-THE BROKEN SWORDS-THE GRAY W'OLF-UNCLE CORNELIUS.

Poetical Yorks of George MacDonald. 2 Vols., cr. 8 vo, buckram, I $2 s$. $\pi$ Threefold Cord. Post $8 \mathrm{vo}$, cloth, 5 s. Heather and Snow. Crown 8 vo, cloth, 3s. 6 . ; post $8 \mathrm{vo}$, illustrated boards, $2 s$.

Uilith. Crown 8vo, cloth, $6 s$.

The Pocket George MacDonald: Passages Chosen by A. H, Hratr. I6mo, clotld gilt, $2 s$, net; lealher gi t, 35 , net. 
MACDONELL. Quaker Cousins. Post 8vo, boardis, 2s.

MACGREGOR (ROBERT). Pastimes and Players: Notes on Popular Games. Post 8vo, cloth, 2s, 6d.

\section{MACHRAY (ROBERT), Novels} by. Crown swo. cloth. 6 s. eacl.

A Blow over the Heart. The Mystery of Lincoln's Inn. The Prilyate Detective.

Her Honour. Crown $8 \%$, cloth, 3 s. $6 d$. MACKAY (Dr. CHAS.).-Interludes and Undertones. Cr.8vo,ctoth, $6 \mathrm{~s}$.

M A K K Y (WILLIAM). - A Mender of Nets. Crown 8 vo, ctolli, $6 s$.

MACKENNA (S. J.) and J. A. U'SHEA. - Brave Men In Actlon: Stories of the British Ftag. With 8 Illustrations by STANLEY L. WoOd. Small demy 8 ro, cloth, gilt edges, $5 s$.

MACKENZIE (IV. A.).-The Drexel Dream. Crown 8vo, cloth, 6s

MACLISE Portrait Gallery (The) of Illustrious Literary Characters : 85 Portraits by DANIEL MACLISE; with Menjoirs by VILliaM BaTks, B.A. Crown 8vo, cloth, 3s. 6 d.

MACMICHAEL (J. HOLDEN).The Story of Charing Cross and its Neighbourhood. With 3 Jllustrations. Denuy svo, cloth, 75. 6a. net.

MACQUOID (Mrs.), Works by, illustrated by T. R. MAcovold. Square Svo, cloth, 6s. each.

In the Ardennes. With so Illustrations,

Plctures and Legends from Normandy-and Brittany. 34 llitusts.

Through Normandy. With 22 lllusts.

$\bar{\Lambda}$ bout Yorkshire. With 67 lllusts.

MAGIC LANTERN, The, and its Mangement. Hy $T$. C. HEPIVORTi. IVitl 10 lllusts. Cr. 8ro, Is. ; ctoth, 1s. (xd.

MAGINA CHARTA : A Facsimile of the Original, $3 \mathrm{ft}$. by $2 \mathrm{ft}$.. with Arms and Seals embtazoned in Gold and Colours, $5 s$.

MALLOCK (W. H.), Works by.

The New Republic. Post 8ro, cloth, 3s. 6.1 ; illustrated boirds, $2 s$.

The New Paul and Yirginia. Posl 8 ro, cloth, 2s. 6 d.

Poems. Small 4to, parchment, 8s.

Is Lite Worth Living? Crows $8 \mathrm{vo}$ buchran, $6 s$.

MALLORY (Sir THOMAS).Mlort d'Arthur, Selections from, cdited by B. M. Rasking. Post 8 ro, cloth, 2s.
MARGUERITTE (PAUL and VICTOR), Novels by.

The Disaster. Translated by F. LEES. Crowu sro, cloth. $3 s .6 d$.

Crown 8ro, cloth, 6s, each.

The Commune. Translated by F. LeEs and $R$. B. DougLs.

Yanity. Translated by K. S. WEST. Witt Portrait Fronlispece.

MARIE DE MEDICIS and the Court of France In the XVIlth Century. Translated from the French of LOUIS BATIFFOL by MIARY KING. With a Portrait. Demy 8vo, cloth. 75. Gd. net.

MARLOWE'S Works, including his Translations. Ediled with Notes hy Col. Cuningham. Cr. 8vo, cloth, 3s. Gi.

MARS H (R I C H A R D). - A Spoller of Mien. Cr. 8 vo, cloth, 3s. $6 . t$.

MASSINGER'S Plays. From the Text of WILIIAM GiFrord. Edited by Col. Cusinguila. Cr. 8vo, cluth, 3s. G!!

MASTERMAN (J.).-Half - a = dozen Daughters. Post 8 vo, bis., 2 s.

MAYFAIR LIBRARY (THE). Post 8vo, cloth limp, 2s. 6d. per rol.

A Journey Round My Room. By XAVIER DE MAJSTRE.

Quips and ouiddities. Selected by V. DAVENPORT ADAMS.

The Agony Column of "The Times," irom 1800 to I870.

Poetlcal Ingenulties and Eccentricities. Edited by W. T. Dorson.

Cupboard Papers. By Fix-13EC.

Songs of Irish Wit and Humour. Edited by A. PKRCEVAL Giraves.

Animals and their Masters. By Sir ARTHUR HELPS.

Soclal Pressure. By Sir A. HELPs,

Curiositles of Criticism. By HeNRY J. J Fxinisg.

Pencil and Palette. By R. KBMPT.

Ourselyes. By E. Lrix Lixrox.

The Autocrat of the Breakfast. Table. Hy U. W. HoLMEs. IIIUs.

Little Essays: Selected from LAMn's LETTERS bY PERCY FITZGERALD.

Theatrical Anecdotes. By JACOB LARWOOD.

Witch Storles, 13y E. LYxx LixTox, Pastimes and Players. By RoIERT MICGREGOR.

The New Paul and Yirginla. Iy WV. H. MALLOCK.

Puck on Pegasus. By H. CirolmoxDELEY.PENIELL.

Pegasus Ro-Saddled. By H. Citot. MONDELEY-PENXELL. Illustrated by $\mathrm{G}$. DU MAURIER.

The Muses of Mayfalr. Edited by H. CHOLNONDFLEY-YEN.XEL.

By Stream and Sea. By IVILLIAM SExior. 
MATTHEWS

(BRANDER).-A Secret of the Sea. Post $8 \%$, illustrated boards, 2s.; cloth, $2 s .6 d$.

M A X O'RELL, B ooks by. Crown 8vo, cloth. 3s. 6d. encls.

Her Royal Highness Woman.

Between Ourselves.

Rambles in Yomanland.

MEADE (L. T.), Novels by.

A Soldier of Fortune. Crown $8 \mathrm{ro}$ cloth, $3 s .6 d$.; post $8 v^{\circ}$, illus!. boards, $2 s$.

Crown 8 ro, cloth, $3 s .6$, each.

The Yolce of the Charmer.

In an Iron Grip. The Siren.

Dr. Rumsey's Patient.

On the Brink of a Chasm.

The Yay of a Yoman.

A Bon of Ishmael.

An Adyenturess. | Rosebury.

The Blue Diamond.

A Stumble by the Yay.

This Troublesome YYorld.

MEDICI SERIES (The) of Reproductions ln Colour from the Oid Masters. For information in regard to this important Series, see Illustrates? Prospectuses to be had upon application

\section{MEDIEVAL LIBRARY}

New). Small crowu $8 \%$ pure paper, half-cloth, 5s. net per vol. ; leather, $7 s .6 d$. net per vol.

1. The Book of the Duke of True Loyers. Translated from the Middle French of CHRISTINe DE PISAN, with Notes and introciuction by ALICE KEsI' WELCH. Woodcut Title and 6 Photogravures.

2. Of the Tumbler of our Lady and other Miracles. Translated from the Middle French of GaUTrke Dk CoINCI, with Notes and Introduction by Alice KesIP WELCH. Woodeut Titlepage and 7 Photogravures.

3. The Lady of Yergl. Translated from the Middle French (which is also given) by ALICE KEMP WELCII, wjth Introduction by Dr. L. BRANDIN. Wood cut Titlepage and 5 Photogravures.

4. The Book of the Diytne Con solation of Saint Angela da Foligno. Translated from the ltalian by MARY C. Stregman. Woodcut Title and reproductions of the origina? IVoodcuts.

MELBA: A Biography, By Elvin Tracey. IVill a Chapter on the Art of Singing by MADAMr. Ml ELBA. and numerous lllustrations. Deny 8 vo cloth, I6s. net.

MERRICK (HOPE). - When a Girl's Engaged. Cr. 8vo, cloth, 3s. $6 \mathrm{~d}$.
MERRICK (LEONARD), Novels

by.

The Man who was Good. Crown 8 ro, cl., 3s. 6 d. ; post 8 ro, illust. bds., $2 s$.

Crown 8 vo, cloth, 35. 6d. each.

Cynthia. | This Stafe of Fools.

MEYNELL (A L ICE).-The Flower of the Mind: a Cholce among the Best Poems. In $16 \mathrm{mo}$, cloth, gilt, 2s, net: leather, 3 s. net.

MILLER (MrS. F. FENWICK). -Physiology for the Young: The Hou se of Life. Illusts. Post 8 vo,cl., 2s.6 $a^{\prime}$.

MINTO (WM.).-Was She Good or Bad? Crown 8vo, cloth, is. $6 d$.

MITCHELL (EDM.), Novels by. Crown 8vo, cloth, 3s. 6d. each.

The Lone Star Rush. With 8 llists. Only a Nigfer.

The Belforts of Culben.

Crown 8vo, picture cloth, flat backs, 2s, each.

Plotters of Paris.

The Temple of Death.

Towards tho Eternal Snows.

MITFORD (BERTRAM), Novels by. Crown sio, cloth. 3s, 6d. each.

Renshaw Fanning's Quest.

Triumph of Hilary Blachland.

Haylland's Chum.

Crown $8 v 0$, cloth, $3 s .6 d$. each; picture cloth, flat back, 2s, each.

The Luck of Gerard Ridgeley.

The King's Assegal. With 6 lilusts.

The Cun-Runner. Cr. 8 vo, cl., 3s, 6l.; Cheap Edition, medium 8vo., $6 d$.

Marley Greenoak's Charge. Crown $8 \mathrm{ro}$, cloth, $6 \mathrm{~s}$.

MOLESWORTH (MrS.). Hathercourt Rectory. Crown 8vo, cloth, $35.6 d$. ; post 8 vo, illust. boards, $2 s$.

MOLIERE: A Biography. By H. C. Chatfiel.d-Taylor. With Introduction by Prof. T. F. Crane, and 10 lllustrations by JOB. Royal 8 vo, cloth, 10s, 6d, net.

MONCRIEFF (W. D. SCOTT-).The Abdlcation: A Drama. With 7 Etchings, Imperial 4to, buckram, $21 s$.

MOORE (THOMAS), Works by. The Eplcurean; and Alciphron. Post svo, balf-cloth, 25 .

Prose and Yerse: including Suppressed Passages from the MENIOIRS OF LORD BYRON. Edited by R. H. SHEPHERD. IVith Portrait. Crown 8vo, cloth, 7s. $6 d$.

MURRAY (HENRY), Novels by. Post 8vo, cloth, 2s. 6il. each.

A Came of Bluff.

A Song of Sixpence. 
MUDDOCK (J. E.), Stories by. Crown 8vo, cloth, 3s. Gd. each.

Basile the Jester.

Young Lochinvar.

The Golden Idol.

Post 8vo, illustrated boards, 2s. each.

The Dead Man's Secret.

From the Bosom of the Deep.

Stories Weird and Wonderful. Post $8 \mathrm{ro}$, illust. boards, 25. : c'oth, 2s. $6 t$.

Maid Marian and Robin Hood. With 12 Illustrations by STANLEY L WOOD. Crown 8ro, cloth, 3s, 6xl.; picture cloth flat back, $2 s$.

MURRA Y (D. CHRISTIE), Novels by. Crown 8 ro, cloth, 3s. Oat. each; post 8vo, illustrated boards, 2s, each. A Life's A tonement.

Joseph's Coat. With i 2 Illustrations. Coals of Fire. With 3 Illustrations.

Val Strange, I A Yasted Crime. A Capful o' Nalls.

The Way of the World.

Mount Despair. | $A$ Model Father.

Old Blazer's Hero.

By the Gate of the Sea.

A Bit of Human Nature.

First Person Singular.

Bob Martin's Little Girl.

Time's Reyenges.

Cynic Fortune. | In Direst Peril.

Crown 8vo, clolh, 3s, 6d, each.

This Little World.

A Race for Millions.

The Church of Humanity.

Tales in Prose and Yerse.

Despair's Last Journey.

Y.C.: A Chronicle of Castle Barfield.

Yerona's Father. Crown 8vo, cloth, $6 s$.

His Own Ghost. Crown 8 vo, cloth, 3s. Gd.: picture cluth. flat back, $2 s$.

Joseph's Coat. Popclar Eiltion, medium Svo. Gd.

Bob Martin's Littlo Girl. CHeap EinitioN. post 8 vo, cloth, is. net.

MURRAY (D. CHRISTIE) and HENRY HERMAN, Novels by. Crown 8ro, cloth, 3s. 6 d. each; post 8 vo, illustrated boards, $2 s$, each.

One Trayeller Returns.

The Blshops' Bible.

PaulJones's Alias. With Illustrations by A. FORESTIKR and G. Nicol.et.

MY FIRST BOOK. By WALTER BESANT, JAMES PAYN, W. CLARK RUSSELL, GRANT ALIEN, HaLl CaINE, GEORGE R. SIMS, RUdYARD KIPIING, A. CoNa.i DOYLE, M. E. BRaDdON, F. IV. RoBINSON, H. RIDER HAGgakd, R. M. B.ALlaNtYNe, I. ZANGWill, MORLEY ROBERTS, D. CHRISTIE MURRAY', MARIE CORElli, J. K. Jerome, JOHN STRANGE WINTER, BRET HARTE, 'Q.,' ROBERT BLCHANAN, and R. L. STEVEN. son. With Prefatory Story by JEROME K. Jerosie, and 185 Illustrations. Demy $8 v o$, art linen, 3s. 6at.
MORROW (W. C.).-Bohemian Paris of To-Day. With 106 lllusts. by EDOUaRd Cucuel. Small demy 8 vo,cl.,6s.

NEWBOLT (HENRY), - Taken from the Enemy. $\mathrm{Fcp} .8 \mathrm{vo}$, pic. cov.. Is.

NISBET (HUME), Books by.

'Ball Up!' Crown 8vo, cloth, 3s. 6l. post 8vo, illustrated boards, 2s. : Popular Edition. medium 8 vo, $6 d$.

Dr. Bernard St. YIncent. Post $8 \%$ illustrated boards, $2 s$.

Lessons in Art. Witl 2 ! lllustrations. Crown 8vo, cloth, 2s. 6d.

NORDAU (MAX).-Morganatic : A Romance. Translaled by Elzabeitir LEF. Crown 8\%o, cloth, gilt top, 6s.

NORRIS (W. E.), Novels by. Crown 8vo, cloth. 3s. 6d. each ; post 8 vo, illustrated boards, 2s. each.

Baint Ann's. | Billy Bellew.

Miss Wentworth's Idea. Crown 8 ro, cloth, 3s. 6d.

OUIDA, Novels by. Crown 8vo, cloth, 3s. $6 d$. each; post 8 vo, illustrated boards, 2s. each.

Tricotrin. A Dof of Flanders.

Rufino. Cecil Castlemaine's Othmar. Oage.

Frescoes. Princess Napraxine.

Kanda. Held in Bondage.

Ariadne. Under Tyo Flags.

Pascarel. Folle-Farine.

Chandos. Tyo Wooden Shoes. Moths. A Yillage Commune.

Puck. In a winter city.

dalla. Santa Barbara.

Bimbi. In Marenima.

Signa. Strathmore.

Frlendship. Piplstrello.

Gullderoy. Tyo Offeziers. Crown $8 v 0$, cloth, $35.6 d$, each,

A Rainy June. I The Massarenes.

Popular Editioss. medium 8vo, 6d. ealia.

Under Two Flag's.

Held in Bondage.

Strathmore.

The Massarenes.

Friendship.

Idalia.

Syriln. Crown $8 v 0$, clolh, 3s. 6d.; post $8 \mathrm{vo}$, picture cloth, flat back, 2s.; illustrated boards, $2 s$.

Two Little Wooden Shoes. LARGE TYPE EDITIOS. Fcap. 8vo, cloth, is, net ; leather, is. Gd. net,

The Yaters of Edera. Crown 8vo, cloth, 3s. 61 .: piclure cloth, flat back, $2 s$.

Santa Barbara. ChEap EdITION, post $8 v o$, cloth. Is, net.

Yisdom, $\mathbf{Y}$ it, and Pathos, selected from the Works of OvIDA by F. SYDNEY MIORRIS. Post 8ro. cloth, 5s.-CHEAP EDITION, illustrated boards, 2s. 
OHNET (GEORGES), Novels by.

Doctor Rameau. PostSvo, illustrated boarcis, 25 .

A Weird Gift. Crown $8 v 0$, cloth, $3 s, 6 d$. : post sro, illustrated boardi, 2 s.

A Last Loye. Post 8 \%o. Illust, bds., as. Crown 8vo, cloth, 3s. 6 , each.

Loye's Depths.

The Money-maker.

The Yoman of Mystery.

Crown Svo, cloth, 0s. each.

The Path of Glory.

Tho Conqueress. Translated by $\mathrm{F}$. ROTHIVELL.

OLIPHANT (MIrs.), Novels by. Post Evo, illustrated boards, zs. each.

The Primrose Path.

The Greatest Helress in England.

Whiteladies, Crown swo, cloth, with I 2 Illustrations, $35,6 d$. : post $8 v 0$, bds., $2 s$.

The Sorceress. Crown $8 v 0$, cloth, $3 s .6 d$.

OSBOURNE (LLOYD), Stories by. Crown svo, cloth, 3 s. Gd, each.

The Motormaniacs.

Threo Speeds Forward. Will Illustrations.

O'SHAUGHNESSY (ARTHUR), Poems by.

Musio \& Moonlight. Fcp. 8vo. cl., 7s.6i. Lays of France. Cr. $8 \%$, cloth, IOs. $6 . l$.

PAIN (BARRY).-Eliza's Husband. Fcap., 8to, is.: cloth, Is. Gd.

PALMER (W. T.), Books by. Crown Svo, clolh, wilh Frontis., 6s, each.

Lake Country Rambles.

In Lakeland Dells and Folis.

PANDURANG HARI; or, Memolrs of a Hindoo. Vith Preface by Sir BARTLE FRERE, Post $8 \%$, illustrated boards, $2 s$.

PARADISE (The) or Garden of the Holy Fathers: Histories of the Anchorites, Recluses, Canobiles, Monks, and Ascetic Fathers of the Deserts of Egypt, belween about A.D 250 and 400 . Translated from the Svriac, with an Introduction, by E. A. WALLIS BCDGE, Litt.D. With 2 Fronlispieccs. 2 vols. large crown 8vo. buckram, I5s. net.

PARIS SALON, The Illustrated Catalogue of the. With about 300 illusirations. Published annually. Dy 8vo, is.

'ASCAL'S Provincial Letters. With Introduction and Notes by $T$. M'CirIE, D.D. Post 8vo, half-cloth, $2 s$.

PASTON LETTERS (The), $1422=$ 1509. Edited, with lutroduction and Notes, by Jasirs GairdNer. Six Vols., demy 8 vo, Jinen, gilt top, 6.3 iss. the set.'

PAUL (MARGARETA).-Gentle and Simple. Crown $8 \mathrm{vo}$, cloth, 3s. $6 d$.; post $8 v 0$, illustrated boards, $2 s$.
PAYN (JAMES), Novels by. Crown 8vo, cloth, 3s. 6\%. each; post 8vo. illusirated boards, 2s. each.

Lost Sir Massingberd.

The Cly ffards of Clyffe.

A County Family.

Less Black than Yo'ro Painted. By Proxy. High bpirits. | Sunny Stories. A Confidential Agent.

A Grapo from a Thorn. 12 llusts. The Family Scapegrace.

Holiday Tasks. I At Her Mercy.

The Taik of the Town. I 2 llus!s.

The Mystery of Mirbridge.

The Word and the Yi11.

The Burnt Million.

A Trying Patient.

Posl Svo, illustrated boards, 2s, each.

Humorous Stortes, | From Exile. The Foster Brothers.

Married Beneath Him.

Bentinck's Tutor.

YXalter's Word. Fallen Fortunes.

A Perfect Treasure.

Like Father, Like Son.

A Woman's Yengeance.

Carlyon's Year. | Cecil's Tryst. Murphy's Master.

Some Private Yieys.

Found Dead. | Mirk Abbey. Grendoline's Haryest.

A Marine Residence.

The Canon's Yard.

Not Yooed, But Yyon.

Two Mundred Pounds Reward.

The Best of Husbands.

Halyes. | What He Cost Her. Kit: A Memory. U Under One Roof. Glow-Worm Tales.

A Prince of the Blood.

A I Jodern Dick Yhittington. Crown 8vo, cloth, with Portrait of Author, 3s. 6i.; picture cloth, fiat back, 2 s.

The Burnt Million. CHEAP EDITION,

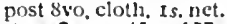

Notes from the 'News.' Crown 8vo, cloth. Is. $6 d$.

foptlar Editioss, medium $8 v o, 6 d$. each.

Lost Sir Massingbord.

Yalter's Yord.

PAYNE (WILL). - Jerry the Dreamer. Crown $8 v^{\circ}$, cloth. 3s. $6 d$.

PENNELL = ELMHIRST (Cap * tain E.).-The Best of the Fun. With 8 Coloured lisustrations and 48 others. Medium 8vo, cloth. 6s. net.

PENNELL (H. CHOLMONDELEY), Works by. Post $8 v o, c l, 2 s, 6 d . c a$, Puck on Pegasus. IVith lllustratuns. Pegasus Re-Saddled. With ro Fullpage lllustrations by $G$. DU MAtrier.

The Muses of Mayfair: Vers de Société. Selected by H. C. PENNELL.

PENNY (F. E.), Novels by. Crown 8vo, cloth, 6 s. each.

The Sanyast. | Dilys.

CasteandCreed. TheTea-Planter. The Ineyltabio Law. 

PERRIN (ALICE), Novels by.

The Yaters of Destruction.

Red Records.

Crown 8vo, cloth, 35.6 . cach.

A Free Solltude. I East of Suez.

PETER PAN KEEPSAKE (The).

The Story retold for Children by DANIEL

O'CoNxor. With numerous Illustrations. Crown 4 to, is. net.

PHELPS (E. S.).-Jack the Fisherman. Illustrated by $C$. W. LEED. Crown 8 in, cloth, is, 6d.

PHIL MAY'S Sketch-Book: 54 Cartoons. Cruwn folio, cloth. 2s. (yt.

PHIPSON (Dr. T. L.), Books by. Crown 8vo, cloth, 5 s. each.

Famous yiolinists and Yiolins.

The Confessions of a Ylolinist.

Yoice and Yiolin.

PILKINGTON (L. L.).-Mallen. der's Mistake. Crown 8 vo, cloth. $6 s$.

PLANCHE (J.R.), Works by.

The Pursuivant of Arms. lith 6 Plates and 200 lllustrations. Crown Sro, cloth, 7s. fol.

Songs and Poems. Ediled by Mrs. MACKARNESS, Crown 8\%o, cloth, 6s.

PLUTARCH'S Lives of IIIUS= trious Men. With Life of PLLTARCH by $J$. and IV. LANGHORNE, and Portraits. Two Vols., 8ro, half-cloth, 105. 6d.

POE'S (EDGAR ALLAN) Choice Works: Poems, Stories, Essays. With an lutroduction by ChakLs HAUDEI-AIRE. Crown Svo, cloth, 35, 6d.

POLLOCK(W.H.).-The Charm, and Other Drawing-Room Plays. By Sir IVALTER BESAXT and WALTER H. POLLOCK, With 5o Illustrations. Crown 8vo, cloth, 3s. $6 d$.

PRAED (MIrS. CAMPBELL), Novels by. Post 8ro, llits, boards, 2s. ea.

The Romance of a Station.

The Soul of Countess Idrian.

Crown svo, cloth, 3s, 6d, cach; post 8vo, illustrated boards, 25, cach.

Outlay and Lawmaker.

Cliristina Chard.

Mrs. Tregaskiss. Wilh 8 Illustrations,

$$
\text { Crown } 8 v 0 \text {, cloth, 3s. 6a. each. }
$$

Nulma.

Madame Izan.

'As a Watch in tho Night.'

Christina chard. CHrap EDITION. post sris. cloth, is, net.

The Lost Earl of Ellan. Crown siv, eloth, 6.s.

PRICK (E. C.). - Valentina. Crown swo, cinth. 3s. 6ot.

PRYCE (RICHAKD). - Miss Maxwell's Affections. Crown 8\%0, cl. $35.64 . ;$ post $8 v o$, illust. boards, $2 s$.
PROCTOR (RICHARD A.), Works by. Crow'n $8 \mathrm{vo}$, cloth. 3s. 6 , each, Easy Etar Lessons. VWith Star Maps for every Niglıt in the Ycar.

Flowers of the $\mathbf{S k y}$. With 55 lllusts.

Famillar Science studies.

Mysteries of Time and Space.

The Universe of Suns.

Baturn and its System. With I3 Steel Plates. Demy rvo, cloth, 6s.

Wages and Wants of Sclence YYorkers. Crown $8 v 0,15$. 61 ,

KAMBOSSON (J.). - Popular Astronomy. Translated by C. IB. Pitalax. YVith 10 Colnurcd Plates and 63 IVondcuta, Crown Rv.. rinth ze roi

RAPPUPUKI (A. \., M.A.).The Curse ot the Romanovs : A Study of the Reigns of Tsars Paul I. and Alexander 1. of Russia, 17,6-1825. With

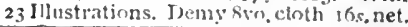

READE'S (CHARLES) Novels. Collected LIBRARY EDItTox, in Seventeen Volumes, crown 8vo, cloth, 3s. 62 each.

Pegs Wofrington: and Christio Johnstone.

Hard Cash.

The Cloister and the Hearth. With a Preface by Sir WALTER BESANT.

'It is Neyer Too Late to Mend.'

The Course of True Love Never Did Run Smooth; and Singleheart and Doubleface.

The Autoblography of a Thief: Jack of all Trades; A Hero and a Martyr; The Yandering Heir. Love Me Little, Loye Me Long.

The Double Marriage.

Grifth Gaunt.

Foul Play.

Put Yourself in HIs Place.

A Terrible Temptation.

A Simpleton.

A Yoman-Hater.

The Jilt: and Good Stories of Man and other Animals.

A Perilous Secret.

Readiana: and Blble Characters.

Also in Twenty-one Volumes, post $8 \% 0$, illustraied boards, 2s, each.

Peg Xoffington. | A Simpleton. Christie Johnstone.

'It is Neyer Too Lato to Mend.'

The Course of True Loye Never Did Run Smooth.

Autobiography of a Thief; Jack of all Trades; James Lambert.

Loye Me LittIe, Loyo Me Long.

The Double Marriage.

The Cloister and the Hearth.

A Terrible Temptation.

Hard Cash. | Readiana.

Foul Play. | Griffth Gaunt. Put Yourself in HIs Place.

The $\mathrm{K}$ andering Helr.

A Yoman-Hater.

Singlehcart and Doubleface.

Good Stories of Man, Nc.

The Jilt; and other stories.

A Perilous Secret. 
READE (CHARLES)-continued.

LARGE TYPE, FINE PAPER EDITIONS.

Pott $8 \% 0$, cloth, gilt top, 25. net each : leather gill edges. 3.r. net each.

The Cloister and the Hearth. Wil 32 Illustrations by M. B. Hewerdist.

'It is Neyer Too Late to Mend.'

Poptlar Editioxs, medium 8vo, 62. each.

The Clolster and the Hezrth.

'It is Neyer Too Late to Mend.'

Foul Play. Hard Cash.

Peg Woffington; and Christle Johnstone.

Griffith Gaunt.

Puc Yourseif in His Place.

A Terrible Temptation.

The Double Marriage.

Loye Mo Littio, Loye Mo Long.

Fcap. 8vo, half-Roxburghe, 2s.62t. each.

Christie Johnstone. With frontis Peg Woffington.

The Wandering Heir. LARGE, TYPF EDITIox, fcap.sro, cloth, is. net ; leather 1s. 6 d. net.

The clolster and the Hearth. EDITION DE LUXE, with I 6 Photogravur, and $8_{4}$ half-tone Illustrations by MAT B. Hewernine. Small 4 to, cloth, 6s. net

Bible Characters. Fcap. 8vo, is.

Selections from the Works of Charles Reade. Edited by Irs. A IRELAND. Post 8vo, clolh, 2s. $6 d$.

RICHARDSON (FRANK), Novels by. Crown 8vo, cloth, 3s. 6r. each.

The Man who Lost his Past. Witl 5o Illustrations by TOsI BRowNE, R.I.

The Bayswater Miracle.

Crown 8vo, cloth. 6s, each.

The King"s Counsel.

Bemi-Soclety.

There and Back.

RIDDELL (Mrs.), Novels by.

A Rich Man's Daughter. Crown 8 vo, cloth, 3s. 64 .

Weird Stories. Crown svo, cloth $35.6 d$.; post $8 \% 0$, picture boards, 2 s.

Pcst 8vo, illustrated boards, 2s. each.

The Uninhablted House.

Prince of Wales's Garden Party.

The Mystery in Palace Gardens.

Falry Yater. I Idle Tales.

Her Mother's Darling.

RIMMER (ALFRED).-Rambles Round Eton and Marrow. With 52 Illustrations, Square 8vo, cloth. 3s. $6 d$.

ROBINSON (F. W.), Novels by.

Women are Strange. Post 8\%o, illustrated boards, $2 s$.

The Hands of Justice. Crown $8 \mathrm{vo}$, ctolh. 3s. 6d.: post $8 v 0$, illust. bds., $2 s$.

The Woman in the Dark. Crown $8 v^{\circ} 0$, clolh, 3s. $6 d, ;$ posi $8 v^{\circ}$, illust, bds, $3 s_{\text {. }}$
RIVES (AMELIE), Stories by.

Crown 8 ro, cloth, $35.6 d$. each.

Barbara Dering.

Meriel : A Love story.

R.OLFE (FR.), Novels by. Crown 8vo, cloth. 6s. each.

Hadrian the Seyenth.

Don Tarquinio.

ROLL OF BATTLE ABBEY, THE: A List of Principal warriors who came from Normandy with William the Conqueror, 1066 in Gold and Cnlnurs si.

ROSENGARTEN(A.).-A Hand. book of Architectural Styles. Translated by W. COLLETT-SANDARS. With 630 Illustrations. Cr. 8vo, clolh, 7s. $6 d$.

ROSS (ALBERT).-A Sugar Princess. Crown 8vo, cloth. 3s. 6d.

ROWLEY (Hon. HUGH). Post $8 v o$, cloth, $2 s .6, t$. each.

Puniana: or. Thoughts Wise and Otherwise: a Collection of the Best Riddles, Conundrums, Jokes, Sells, \&c., wilh numcrous Illustrations.

More Punlana. Wilh numerous Illusls.

R OW S E L L (MAR Y C.), Monsieur de Paris. Crown $8 \%$, clnth, $3 s .6 \%$.

RUSSELL (W. CLARK). Novels by. Crown $8 \mathrm{vn}$, cloth. 6s. each.

Overdue. | Wrong side Out.

Crown $8 v 0$, cloth, 3s. 6d. each : post 8vo, .llustrated boards. 2s. each : cloth. 2s. 6d. each.

Round the Galley-Fire.

In the Middle Watch.

On the Fo'k'sle Head.

A Yoyage to the Cape.

A Book for the Hammock.

The Mystery of the 'Ocean Star.'

The Romance of Jenny Harlowe.

The Tale of the Ten.

An Ocean Tragedy.

My Shipmate Louise.

Alone on a Yide Ylde Sea.

The Good Ship. Mohock.'

The Phantom Death.

Is He the Man? | Heart of Oak. The Conylict Ship.

The Last Entry.

Crown $8 \mathbf{x}^{\circ}$, clolh, 3s. 6d, each.

A Tale of Two Tunnels.

The Death Ship.

The Ship: Her Story. With so Illuslrations by H. C. SePpIxGs IVRIGHT. Small 4 to, cloth. $6 s$.

The 'Pretty Polly.' IVith 12 Illuslra. tions by $G$. E. ROBERTSON. Large crown $8 v 0$, cloth, gilt edges, $5 s$.

The Convict Shlp. POPULAR EDITION; uedium $8 \% 0,6 d$. 
RUNCIMAN (JAS.), Stories by. Schools and Scholars. Post 8vo, cloth, 2s. $6 d$.

Skippers and Shellbackg, Crown $8 v 0$, cloth, 3s. 6d.

RUSSELL (DORA), Novels by.

A Country $\mathbf{s}$ weetheart. Crown svo, picture cloth. Hat back, 25.

The Drift of Fate. Crown Svo, cloth, 3s. 6d.: piclure cloth, flat back, $2 s$.

RUSSELL (Rev. JOHN) and his Out-of-duor Life. By E. WV. L. DAVIES. W'ith Illustrations coloured by hand. Royal svo, cloth, I6s. net.

RUSSELL (HERBERT).--True Blue. Crown 8vo, clotlı, 3s. 6ut.

RUSSIAN BASTILLE, THE (The Fortress of Schlucssclburg). By T. P. YouvatsIIEV. Translated by A. S. RAProport. M.A. With numerous lilustrations. Demy 8vo, cloth, 7s. 6d. net.

IPrefaring.

SAINT AUBYN (ALAN), Novels by. Crown 8vo, cloth, 3s. 6i, each; post $8 v 0$ illustraled boards, $2 s$, cach.

A Fellow of Trinity. With a Note bY OLIVER WENDELL HOLMES.

The Junior Dean.

Orchard Damerel.

The Master of St. Benedict's.

In the Face of the World.

To Hls Own Master.

The Tremlett Dlamonds.

Crown $8 v o$, cloth, 3s. 6d, each.

The Yooing of May.

Fortune's Cate.

A Traglc Honeymoon.

Gallantry Bower.

A Proctor's Yooing.

Bonnie Maǵgie Lauder.

Mrs. Dunbar's Secret.

Mary Unyin. With $\times$ Illustratione.

SAINT JOHN (BAYLE). - A Levantine Family. Cr. 8vo. cl.. 3s. 6 d.

SALA (G. A.).-Gaslight and Dayllght. Post 8 vo, illustrated boards, 2s.

SA LMON (A. L.).-Lit erary Rambles in the West of England. With a Frontispiece. Cr. $8 \% 0, \mathrm{cl}_{n}$ os. net.

SCOTLAND YARD, Past \& Present By Ex-Chief-Inspector Cavanagir. Post 8vo, illustrated boards, 25 . : cloth, 2s. $\epsilon d$.

SERGEANT (ADELINE), NoveIs by. Crown $8 \% 0$, cloth, 35, 6d. each.

Under False Pretences.

Dr. Endicott's Experiment.

The Missing Ellzabeth. Crown 8 ro, sluth, os.
SECRET OUT SERIES (The).

Crown 8vo, cloth, with numerous

lilustrations, 4s. 6d. each.

The Secret Out: One Thousand Tricke with Drawing-room or While Magic. By W. H. CKEMEI?. IVIth 300 Engravings.

The Art of Amuging: A Collectlon of Graceful Arts, Ganes, Tricks, Puzz!es, and Charades, By FKa.k BeLLEW' With 300 Illustrations.

Hanky - Panky : Very Easy Tricks, Very bifticult Tricks, White Magic, Sleight of Hand. Edited by IV. H. CNESER. With 200 Illustrations.

The Magician's Oyn Book: Per formances with Cups and Balıs, Eges, Hals. Handkerchiefs, \&c. Edited by IV. H. CREMER. With 200 Illustratlons,

The Complete Art of Fireyork. Making: or, The Pyrotechnist's Trcasury. By THONAS KeNTISII. Vith 267 Itlustrations, $35.6 d$.

ST. MARTIN'S LIBRARY (The). In pocket size, cloth, gill top, 2s. net per Vol. ; leather. gill edges, 3s. net per Vcl. By SiR WALTER Jitsaxt.

London.

Westminster.

Fll gorts and Conditions of Men.

Sir Richard Yhittington.

Gaspard de Collgny.

By HALL CAJNE.

Tho Deemster.

By W11.kie Col.LiNs.

The Yoman in Yhite.

By DANJEL DElOE:

Robinson Crusoe. With 37 ithustrations by G. CRUIKSHANK.

BY ChARLES DICKENS.

Speeches. With Portrall.

By ALsti: DOBSON.

EIghteonth Century Yignettes. inree Series, each lllustrated.

By THOMAS HARDY.

Under the Greenwood Tree. BY BRET HARTE.

Condensed Noyels.

By Oliver Westell Holirf.

The $\overline{\text { Iutocrat }}$ of the Breakfast.

Table. Illustrated by J. G. Тноміs .

Compiled bv A. H. HYATT.

The Charm of London: An Anthology. By RICHARD JEFFERIES.

The Life of the Fields.

The Open Air.

Nature near London.

By CHARLES LAMB.

The Essays of Ella.

By LORD MACALLAY.

History of England, in 5 Volumes.

By JustiN MCCARTII:

The Reign of Queen Anne, in I Vol.

A History of the Four Georges and of Yilliam IY., in 2 Vols.

A History of Our Orn Times from Accession of $Q$. Victoria to 1897 , in 3 Vols. 
ST. MARTIN'S I.IBRARY-continuc!. 13y GEORGE MACDONALD.

Yorks of Fancyand Inigination, in 10 Vols. (For List, see p. 18.)

By CHARLES RENDE.

Tho Cloister and the Hearth. With 32 Illustratious by M. B. H EW ERDINE.

'It is Never Too Late to Mend." BY ROBERT LOUIS STEVENSON.

An inland Yoyage.

Trayels with a Donkey.

Memories and Portzalts.

Yirginibus Puerisque.

Men and Books.

Nex Arabian Nights.

Across the Plains. | Merry Men. Collected Poems.

\section{By 11. A. TMXE}

History of English Literature, in 4 Vols. Witls 32 Portraits.

By MARK TWAIx.-Sketches.

By IVALTON and Cottox:

The Complete $\mathbf{A}$ ingler.

\section{SEELEY (E. L.), Books by.}

Stories of the Italian Artists from Yasar1. Large crown 8ro buckram, with 8 Four-Colour Plates and 24 lis Half-tone, $75.6 d$. net. EDITiON Dk LUXE, demy Svo, with additional Coloured Mates, and with otlier plates in Two Tints, parchment, I5s. net; vellum, 20s. net: norocco, 30s, net.

Artists of the Italian Renaissance: their Stories, as set forth by VASARI, RIDOIFI, LANZI, and the CIIRONICLERS, Large crown $8 \mathrm{vo}$, buckram, with 8 Four-Colour Plates and 24 in Half-tone, 7s. 6،. net. EDITION DELUXE, deny 8ro, with additional Coloured Plates, and with other plates in Two Tints, parchment, I5s. net ; vellum, 20s. net; morocco, 30s. net.

SENIOR (IVM.).-By Stream

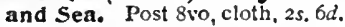

SEYMOUR (CYRIL), Novels by. Crown 8vo, cloth, 6s. each.

The Maglc of To-Morrow.

comet Chaos.

SHA KE SPEARE LIBRARY (The). PART I

\section{THE OLD-SPELLING} SHAKESPEARE.

In Furty Volumes, demy 8 vo. cloth, 2s.6xl. net per vol.; or Library Edition (sold only in sets), pure rag paper, halfparchment, $\mathbf{s}$, net per vot. To be issued at short intervals.

The Works of William Silakespeare with the spelling of the Quarto or the Folio as the basis of the Text, and all changes marked in heary type. Edited, with brief Introductions and Notes, by F. J. Furnival, M.A., D. Litt. The COMEDIES will be issued first, followed by the HISTORIES, TRAGEDIES, and POEMS.
SHAKESPEARE L,IBRARY-cont.

PART II.

THE SHAKESPEARE CLASSICS. Small crown 8 ro, quarter-bound antique grey boards, $2 s .6 d$. net per vot.; whole gold-brown velvet persian, $4 s$. net per vol. : atso 500 speciat sets on larger paper, half parchment, gilt tops (sold in sets only), 5s. net. per vol, Each volu:ue with Frontispiece.

1. Lodge's 'Rosalynde': the original of Shakespeare's 'As You Like It." Edited by IV. W. GREG, $31 . A$.

2. Greene's 'Pandosto,'or'Dorastus and Fawnia': the original of Shairespeare's 'YIintor's Tale:' Edited by l'. G. Thonlas.

3. Brooke's Poem of 'Romeus and Jullet': the original of Shakespeare's 'Romeo and Jullet. Edited by $P$. A. DAxivl. Modernised and re-edited by J. J. Mexio.

4. 'The Troublesome Reign of King John': the Play revyritten by Shakespeare as 'KIng John.' Edited by F. J. FurNiVALL, D.Liti.

5.6. 'The History of Hamlet': Vith other Documents illustrative of the sources of Shakspeare's Play, and an Introductory Stuay of the LEGEND OF HaMlet by Prof. I. Gollaxicz.

7. 'The Play of King Leir and His Three Daughters': the old play on the subjoot of King Lear. Edited by SIDAFY LEE, D.Litt.

8. "The Taming of a Shrew': Being the old play used by Shakespeare in 'The Taming of 'The Shrew,' Vdited by Professor F.S. BOAS.

9. The Sources and Analogues of 'A Midsummer Night's Dream.'

10. The Famous Ylotories of Henry' $\mathbf{y}$.'

11. 'The Menæchmi': the original of Shakespeare's 'Comedy of Errors.' The Elizabethan Trinsla. tion.

12. 'Promos and Cassandra': the source of "Measure for Measure.'

\section{PAR I III.}

\section{THE LAMB SHAKESPEARツ} FOR YOUNG PEOPLE.

With lltustrations and Music. Based on MARI AND CHARLES LAMIB's TALES FROM SHAKESPEARE, an attempt being made to insert skilfully within the setting of prose those scenes and passages from the Plays with which the young reader should early become acquainted. Imperial $16 \mathrm{mo}$, cloth, is. $6 d$. net per vol, ; leather, 2s. 6d. net per vol.; Special School Edition, linen, $\$ d$, net per vol. 'THE TEMPIST' nay also be had in a 
SHAKESPEARE LIBRARY-cont. Special Gift Edition, without the music, cloth, 1s. $6 d$. net ; leather, 2s. $6 d$. net.

I. The Tempest. Illustrated by HeLEx STRATTON.

11. As You Like It. Illustrated by L. E. WRIGHT.

1II. A Midsummer Night's Dream. Iilustrated by HELEN STRATTO:.

IV. The Merchant of Yentce.

v. KIng Henry $\mathbf{y}$.

Vi. Twelfth Night.

Vii. A Life of Shakespeare for the Young.

\section{PART IV}

SHAKESPEARE'S ENGLAND.

Part IV. will embody a series of volumes illustrative of the life, thought and letters of England in the time of Sisakespeare. The first volumes are-

Robert Laneham's Letter, describing part of the Entertainment given to Queen Elizabeth at Kenilworth Castle in 1575. With Introduction by Dr. FERNIVALL. Demy 8vo, cloth, 5s, net.

The Rogues and Yagabonds of Shakespeare's Youth : reprints of Awdeley's 'Praternitye of Vacabondes,' Harman's 'Caveat for Common Cursetors,' Parson Haben's or Hyberdyne's 'sermon in Praise of Thieves and Thievery;' \&c. With many wodcuts. Ediled, with Introtuction, by EDWARD Viles and Dr. Fl'rNivale, Denyy 8 ro, cloth, 5 s, net.

Shakespeare's Holinshed : a reprint of all the passages in Holinshed's 'Chronicle' of which use was made in Shakespeare's Historical Plays, with Notes and Index. Edited by $W$. G. Boswell StoNe. Royal 8vo, cloth, jos 64. net.

The Book of Ellzabethan Yerse. Chosen and Edited, with Notes. Index of Authors, Biographical Index of Authors. and Index of lirst lines, bv IVILLIaM STANLEY BRAITHWaITE. With Frontispiece and Vignetie. Small crown \&vo, cloth, 6s. net: nolished calf, I 2s. fid. net.

Tho Shakespeare Allusion Book. Reprints of all known references to Shakespeare and his works before the slose of the seventeenth century, collected by Dr. IxGLrBß, Miss L. TOLLutw Sintul, Dr. Flentvali, and arranged in chronological order. Two vols. rov. 8 vo.

Harrison's Description of England. Part IV. Cniform with Parts 1.-111. as issued by the New Shakspere Society. (250 copies only.) 17s. 6d. net.

Shakespeare the Boy: The Home and School Life, Games and Sports, Manners, Customs, and Folk-lore of the Time, By W. J. ROLFE. With 42 Illustrations. Cruwn 8ro, cloth, 35, 6d.

Shakespeare's Sweetheart: a Romance. By S.IPAH HI. STERLING. With 6 Culoured Illustrations by C. E. PECK. Square $8 \mathrm{ro}$, cloth, 65 .
SHERIDAN'S (RICHARD BRINSLEY) Complete Works. Crown 8vo, cloth, 3s. 6d.

The Riyals, The School for Scandal, sc. Post \$vo, half-cloll, $2 s$.

Sheridan's Comedies: TheRiyals ald The $\mathbf{5 c h o o l}$ for Scandal. Fdited by BRANDER MaTTHEW's. With Illustratlons. Demy 8vo, buckram, $12 s, 6 d$.

SHIEL (M. P.), Novels by.

The Purple Cloud. Cr. 8 *o, cloth, $35.6,1$. Unto the Third Generation. Cr.8vo cloth. 6 s.

SIGNBOARDS: Their History, in. cluding Famous Taverns and Remarkable Characters. BY JACOB LARWOOD and J. C. HotTEN. With 95 Illustrations. Crown 8 vo, cloth, $3 s .6 d$.

SIMS (GEORGE R.), Books by. For Life-and After. Cr. $80^{\circ}, \mathrm{cl}, 6 s$.

Pos! \&vo, illustrated boards, 2s, each; cloth limp. 2s. 6i. each.

The Ring o' Bells.

Tinkletop's Crime. | Zeph. Dramas of Life. With 60 Illustrations. My Two Wiyes. I Tales of To-day. Memolrs of a Landiady.

Scenes from the Show.

The Ten Commandments.

Crown Evo, picture cover, is. each; cloth, Is. $6 d$, each.

The Dagonet Reciter and Reader. The Case of George Candlemas.

Dagonet Dittles. Lifo We Lixe. Young Mrs. Caudle.

Li Ting of London.

Crown 8vo, cloth, 3s. 6.t. each: post Sro, picture boards, $2 s$. each; cloth, $2 s .62$. each.

Mary Jane's Memolrs.

Mary Jane Married.

Dagonet $\mathbf{A}$ broad.

Rogues and Yagabonds.

Crown 8 ro, cloth, 3s, Gd. each.

Once upon a Christmas Time. With 8 Illustrations by CHAS. GREEx, R.I.

In Londion's Heart.

A Blind Marriage.

Without the Limolight.

The Small-part Lady.

Blographs of Babylon.

His Wife's Reyenge.

The Mystery of Mary Anne, \&c.

Among My Autographs. 7o Facsims,

Picture cloth, fiat back, 2s, each.

Rogues and Yaǵabonds.

In London's Heart.

Popelar Editioss, medium Sro, $6 d$, each.

Mary Jane's Memolrs.

Roǵces and Yagabonds.

How the Poor Live; and Horrible London. Crown $8 v^{\circ}$, leatherette, is. Dajonet Dramas. Crown $8 v 0,1 s$. 
SHARP (WILLIAM)-Children of To-morrow. Crown 8vo, cloth. 3s. $6 d$.

SHELLEY'S Complete WORKS in Verse and Prose. Edited by $R$. IIERNE SHEPIIERD, Five Vo!s, crown $8 \mathrm{ro}$, cloth, 3s. $6 \mathrm{~d}$. each.

Poetlcal Yorks, in Three Vols.:

Vol. I. Margaret Nicholson; Shelley's Correspondence with Stockdale; Wandering Jew: Queen Mab; Alastor: Resalind ano Helen ; Prometheus Unbound : Adonais.

Vol. II. Laon and Cythna: The Ceuci; Iulian and Maddalo : Swellfoot the Tyrant: The Witch of Atlas; Epipsychidion : Hellas. Vol. III. Posthumous Poens: The Masque of Anarchy; and other Pieccs.

Prose Works, in Two Vols. :

Vol. I. Zastrozzi; St. Irvyne; Dublin and Marlow Pamphlets; Refutation of Deism:

Letters to Leigh Hunt : Minor Writings.

Vol. II. Essays: Letters from Abroad

Translations and Fragments : a Biography

SHERARD (R. H.).-Rogues. Crown 8vo, cloth, I.s. $6 d$.

SHERWOOD (MARGARET). DAPHNE : a Pastoral. With Coloured Frontispicce. Crown 8ro, cloth 3s. $6 d$

SISTER DORA. By M, LONSDALE. Demy 8 vo, $4 d$.; cloth, $6 d$.

SLANG DICTIONARY (The): Historical and Anecdotal. Cr. 8vo. cl..6r. 6d

SMITH (J. MOYR), Books by.

The Prince of Argolis. With 13 Illustrations. Post $8 v^{\circ}$. cloth, 3s. fit.

The Wooing of the Water Witch With Itlustrations. Post 8vo, cloth. 6s.

SNAZELLEPARILLA. Decanted by G.S. EDWARDS. With 66 lllustratione Crown $8 v 0$, cloth, $3 s .6 \%$.

SOCIETY IN LONDON. Crown 8 vo, Is.; cloth, Is. $6 d$.

SOMERSET (Lord HENRY).Songs of Adieu. 4to, Jap. vellum, 6s

SOWERBY (M. and G.), Children's Books by.

Bumbletoes: $t$ lueir Adventures witl Belindla and the Butions Boy, picture in 12 Coloured Scenes and is other Illustrations by MILLICENT Sowrrby With Yerses by GITHa SowERBY. Simal crown $8 \mathrm{vo}$, decorated boards, Is. 6ll, net.

Childhood: Twelve Days from onil Youth. Pictured in Colours by MILLI, CENT SOWERBY. and written in Verse by Githa SOWEREY. Crown 4 to, decorated boards, 3s. $6 d$. net.

SPENSER for Children. By M. H TOwRY. With Coloured Illustrations by

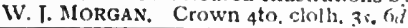

SPETTIGUE (H. H.). - The Heritage of Eve. Cr. Svo, cloth, $6 s$.
SPEIGHT (T. W.), Novels by.

Post 8vo, illustrated boards, 2s. each.

The Mysteries of Heron Dyke.

By Deylous Yays.

Hoodyinked; \& Sandycroft Mystery. IThe Golden Hoop. Back to Life. I Ouittance in Fuil. The Loudwater Tragedy.

Burgo's Romance.

A Husband from the Sea.

Crown 8 vo, cloth. $3 s .6 d$. each.

Her Ladyship. | The Grey Monk: The Master of Trenance.

The Secret of Wyyern Toyers. Doom of Siva. | As it was W ritten The Yob of Fate.

Experiences of Mr. Yerschoyle.

Stepping Blindfold: Cr. 8vo, cloth, 6 . Yife or No Wife.Post 8 vo, cloth, 1s. $6 d$.

SPRIGGE (S. SQUIRE). - An Industrious Chevalier. Cr. 8vo, $6 s$.

STAFFORD (JOHN), Novels by.

Dorls and $I$. Crown $8 v 0$, cloth, 3s. $6 d$. Carlton Priors. Crown 8vo, cloth, $6 s$.

ST A N LEY (WINIFRED). - A Flash of the WIII. Cr. 8vo, ctoth. $6 s$.

STARRY HEAVENS Poetical Birthday Book. Pott 8vo, clnth, 2s. $6 /$.

STEDMAN (E. C.).-Victorian Poets. Crown 8vo. cloth, os.

STEPHENS (RICCARDO).--The Cruciform Mark. Cr. $8 \mathrm{vo}, \mathrm{cl} . .3 s, 6 t$.

STEPHENS (R. NEILSON). Phillp WInwood. Cr. Svo. cl, 3s. $6 d$.

STEPNIAK (S.).-At the Dawn of a New Reign: a Study of Modern Russia, Crown 8vo, cloth. 6 .

STERNDALE (R. ARMITAGE). -The Afghan Knife. Post 8vo, cloth, is. 6 d. : illustrated boards, $2 . s$.

STERNE (LA URENCE). A Sentimental Journey. With 8 . Illustrations by $T$ H. RoBIxson, and a Photogravure Portrait. Crown 8vo, cloth gilt, 3 s. $6 \%$.

The Llfe ot Laurence Sterne. IBy PERCY FITZGerald, With Portrait. Crown 8\%o, cloth, $6 s$.

STEVENSON (BURTON E.)Affairs of State. Crown 8 vo, cluth, 3s. Get.

STOCKTON (FRANK R.).-The Young Master of Hyson Hall, With 36 Illustrations. Crown 8vo, cioth, 3s. 6 t. : picture cloth. flat back, $2 s$.

STODDARD (C. W.), Books by. Port 8ro, cloth, gilt top, 6s. net each. South-Sea IdyIs : Summer Cruising. The Island of Tranquil Delights. 

ST EVENSON (R. LOUIS),

Travels with a Donkey. With a Frontispiece by WALTER CRANE.

An Inland Yoyage. With a Frontispiece by VVALTER CRANE.

Familiar Studies of Men \& Books.

The Silverado Squatters.

The Merry Men.

Under woods: Poems.

Memorles and Portralts.

Yirginibus Puerisque.

Ballads. I Prince Otto.

Across the Plains.

Yelr of Hermiston.

In the South Seas.

Essays of Trayel.

Tales and Fantasies.

Essays in the Art of Yriting.

A Lowden Sabbath Morn. Iliustrated by A. S. BOYD.

Songs of Trayel. Cr. 8vo, buckram, 5 ,

New Arablan Nights. Crown 8ro.

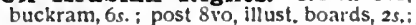
POPULAR EDITION. medium 8vo, $6 d$.

Post svo half-cloth, is. net each; leather, 2s, net each.

Prayers Written at Yallima.

A Christmas Sermon.

TheSulclde Club; and The Rajah's Dlamond. (From NEW ARABLAN Nighes,) With 8 Illustrations by W. J. HexNessy, Crown 8vo, cloth, 3s. 6d.

The Steyenson Reader. Edited by LLOYD OSBOURNE. PUSt $8 \%$, cloth, 2s, $6 d_{\text {. }}$; buckram, gilt tcp. 3s. $6 d$.

The Pocket R.L.S.: Favourile Passages, $16 \mathrm{mo}$. cl., $2 s$, net : leather, $3 s$, net.

LAKGE TYPE, FINE PAPER EDITIONS.

Pott $8{ }^{\circ} 0$, cloth, gilt top, 2s. net each leather. cilt edges, 35. net each.

An Inland Yoyage.

Trayels with a Donkey.

Yirginibus Puerisque.

Familiar Studies of Men \& Books.

New Arabian Nights.

Memories and Portraits.

Across the Plains.

The Merry Men.

Collected Poems of R. L. S.

R. L. Stevenson: A Study, By H, B. BALLDON. With 2 Portraits, Crown 8 vo, buckram, $6 s$,

Recollectlons of R. L. Stevenson in the Paclfic. By ARTHCR JOHxSroxis. With Portrait and Facsinile Letter. Crown 8vo, buckram, 6s, net.

STRUTT (JOSEPH). - The Sports snd Pastlmes of the People of England. With I 40 lllustrations. Crown 8vo, cloth. 3 s. 6 d.

STUART (H.L.)-Weeping C ross. Crown 8vo, cloth, $6 s$.

SUNDOWNER, Stories by.

Told by the Tafirall. Cr. $8 v 0,35,6 d$

The Tale of the Serpent. Crown sio, cloth, flat back, 25 .

STRAUS (RALPH).-The Man Apart. Crown 8vo, clolh, $6 s$.

SUFFRA G ETTE'S LQVELETTERS (A). Crown 8vo, Is, net ; clotl. I . 6d. net.

SULTAN (THE) AND HIS SUBJECTS. By RICHARD DAVEY, With Portrait. Demy 8vo, cloth, 75. 6d. net.

SUTRO (ALFRED). - The Foollsh VIrgins: Fcp. 8 \%o, is.; cl. Is. 6 d.

SWEET (ALEX. E.) and J. ARMOY KNOX.-On a Mexican Mustang Through Texas, from the Gulf to the kio Grande. With 265 Illustrations. Demy 8 ro, cloth. 3 s. $6 d$.

\section{SWINBURNE'S CHARLES) Work.s.}

Selectlons from Mr. Swinburne's Works. Fcap, 8vo, 6s.

Atalanta in Calydon. Crown 8 ro, $6 s$. Chastelard: A Tragedy. Crown 8vo, 75. Poems and Ballads. FIRST SERIES. Crown 8vo. 9.s.

Poems and Ballads. Secono Series. Crown 8vo. 9r.

Poems and Ballads. TIIIRD SERIES. Crown 8vo, $7 s$.

Songs before sunrise. Crown 8 vo, Ios. $6 d$.

Bothwcll : A Tragedy. Crown 8vo, 12s.6.t.

Songs of Two Nations. Crown $8 v, 6 s$.

George Chapman. (In Vol. II. of G. CHAPMAN's Wigrks.) Crown 8vo, 3s. $6 d$.

Essays and Btudies. Crown 8 vo, $12 s$.

Erechtheus: 1 Tragedv. Crown 850,6s.

A Note on Charlotte Bronte. Crown 8 vo, 6s.

A Study of Shakespeare. Crown $8 \mathrm{v}, 8 \mathrm{~s}$.

Songs of the springtides. Crown 8 vo. 6 .

Studies in Song. Crown 8 vo, 7s.

Mary Stuart: A Tragedy. Crown $8 v o, 8 s$.

Tristram of Lyonesse. Crown 8vo, 25 .

A Century of Roundels. Small 4 to, $\varepsilon$.s.

A Midsummer Hollday. $\mathrm{Cr} .8 \mathrm{vo}, 7 \mathrm{~s}$.

Martno Fallero: A Tragedy. Crown 8 ro, $6 s$.

A Study of Ylctor Hugo. $\mathrm{Cr} 8 v 0,6 s$.

Miscellanies. Crown $8 \% 0,125$.

Locrine: A Tragedy. Crown 8vo, 6s.

A Study of Ben Jonson. Cr. $8 v 0,75$,

The Sisters: A Tragedy. Crown 8vo, 65 .

Astrophel, \&c. Crown 8vo, $7 s$.

Studies in Prose and Poetry. Crown svo, 9s.

The Tale of Balen. Crown 8vr. $7^{\circ}$

Rosamund, Queen of the Lom. bards: A Tragedy. Crown 8vo, 65.

A Channel Passage. Crown 8ve. is.

Loyo's Cross-Currents A Yeai's Letters. Crown 8ro, 6s. net.

Yillam Blake. Crown $8 v o, 6 s$. net.

Mr. Sxinburne's Collected Poems. In 6 Vols., crown 8vo, 36 s. net the set.

Mr. Swinburne's Collected Tragedies. In 5 Vo!s., cr.Svo, 3os, net the set. 
SURTEE E

(ROBERT)

Handley Cross; or, Mr. Jorrocks's Hunt. With 79 lllusts, by JOHX LEECH. Post 8ro, picture corer, Is. ; cloth, as.

SWIFT'S (Dean) Choice Works, in Prose and Verse. With Memoir, Portrait, and Facsimiles. $\mathrm{Cr} .8 \mathrm{vo}, \mathrm{cl} ., 3.5,6 d$.

Gulliyer's Traxels, and $A$ Taie of a Tub. Post 8ro, half-cloth, $2 s$.

Jonathan Swift: A Study. By J. CHitRTon Colliss, Cr. Svo, cl.. ss. 6 .

\section{TAINE'S History of English} Literature. Trans. byHENRY VAX LAUN. Four Vols., demy Sro, cl., 30s.-POPUlar EDrriox, Two Vols., crown $8 \mathrm{ro}, \mathrm{cl}$., I5s. FINE PAPER EDtTIOx, in Four Vols., with 32 Portraits, pott Sro, cloth, gilt top, $2 s$, net per vol, ; leather, gilt edges, $3 s$, net per vol.

\section{TALES FOR THE HOMES.}

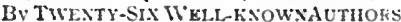
Edited by Rev. J. Marchat, Publishec for the benefit of the BARNARDO MIE MOR1AL Fexd, With 3 Portraits. Crown svo. cloth. 5s. net

TAYLOR (TOM).-Historical

Dramas. Crown 8vo, 1s. each.

' Jeanise Darc.

'TwIXT AXE AND CROW.'.'

'THE FOOL'S REVENGE,"

'ARKWRIGHT'S VIJFE.

'ANXE BOLEYN:"

'PLOT AND PASSION.'

TEMPLE (SIR RICHARD).-AA Blrd's-eye View of Plcturesque Indla, With 32 Illusts. Cr. $8 v^{\circ}$. cl.. 65

THACKERAYANA : Notes and Anecdotes. With numerous Sketches by THACKERAY. Crown 8vo, cloth, 3s. 6t.

Thackeray (The Pocket). Arranged by A. H. HYarT, Jn I6mo, cloth, gil top. 2s. net : leather. gilt top. $3 s$. nel.

THOMAS (ANNIE), Novels by. The Siren's Yleb. Cr. 8 vo, cl., 3s. G.i.

Comrades True. Crown Sso, cloth, 6s.

THOMAS (BERTHA), Novels by.

In a Cathedral City. Cr. Svo, cl., $3 s_{.} 6 d$. Crown $8 \% 0$, cloth, 6s. each.

The Houso on the Scar.

'The Son of the House.

THOMSON'S SEASONS, and The Castle of Indolence. With 48 Illus. trations, Crown 8ro, cloth silt, with Steel Plates, 7 s. 6 d.; post $8 \mathrm{vo}$, half-cloth. 25

THOREAU: His Life and Aims. By A. H. PAGE. With a Portrait. Post 8vo, buckram, $3 s$. $6 d$.

THORNBURY(WALT.), Books by

The Life and Correspondence of J. M. W. Turner. Wjith 8 Coloured Illusts. and 2 Voodeuts. $\mathrm{Cl}, 8 \mathrm{vo}, \mathrm{cl}, 35.6 d$.

Tales for the Marines, Post $8 v^{\circ}$ illuslrated boards, $2 s$.
TIMBS (JOHN), Works by. Crown $8 v^{\circ}$, cloth. $3 s_{.} 6 d$. eacl.

Clubs and Club wife in London. V'ith 4 I Illustrations.

English Eccontrics and Eccentriclties. With 48 Illusirations.

TOMPKINS (HERBERT W.).Marsh-Country Rambles. Vith a Frontispiece. Crown $8 v 0$, cloth, 6 s.

TREETON (ERNEST A.).-The Instigator. Crown sro, clotis, 6e.

TURENNE (RAYMOND).-The Last of the Mammoths, Crown Sro, cloth, 3s. Gul. net.

TWAIN'S (MARK) Books.

Author's Edition de Luxe of the Works of Mark Twain, in 23 Volumes (linited to 600 Numbered Copies), price I2s, 6d. net per Volume. (Can be subscribed for only in Sets.)

UNIFORN LIBRARY EDINION, CrOwn 8\%o, cloth, 3s. $6 \%$, each.

Mark Twain's Llbrary of Humour With ron Illustrations by E. W. Kesibl.

Roughing It: and The Innoconts at Home. With 200 lllustrations by F. A. FRASER.

The Amexican Claimant. With. 81 Illustrations by HAL HirsT and others.

The Adyentures of Tom Sayyer With I1 I Ilustrations.

Tom Sawryer Abroad. With 26 lliustrations by DAN BEARD.

Tom Sawyer, Detectiye, With Port.

Pudd'nhead Wilson. With Portrait and Six Illustrations by LouIS LOEB.

A Tramp Abroad. With 314 Illusts.

The Innocents $\bar{A}$ Troad: or, New Pilgrim's Progress. With 234 Iliusts.

* The Gilded Age. BV Mark Tuval and C. D. WARNER. With 212 Illusts,

The Priluce and tho Pauper. With rgo lilustrations.

* Life on the Mississippi. 300 Illusls.

The Adxentures of Huckleberry Finn. I7t Il!usts. by E. IV KENBLE.

* Yankee at the Court of King Althur. 220 Illusls. hy II.X BEARD.

- The Stolen Yhite Elephant.

The $£ 1,000,000$ Bank-Note.

A Double-barrelled Detectlyo Story: With 7 Illus!rations.

Personal Recollections of Joan of Arc. With I2 Illusts, by F. V. DU MOND.

More Tramps Abroad.

The Man that Corrupted Madley. burg. With Frontispiece.

The Choice Works of Mark Train. With Life, Portrait, and Illustrations.

* The Pooks marked t may be had alsoin post Svo, picture cloth. at $2 s$. each.

Mark Tyain's Sketches, Pott 8ro, cloth, gilt top, $2 s$. net; leather, silt edges. 35 . net: picture boards, $2 s$.

A Tramp Abroad. Cheap Editios,

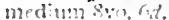


TROLLOPE (ANTHONY), Novels by. Crown 8 vo, cloth, 3s. Gd. each; post $85^{\circ}$, illustrated boards, 2s. eacli,

The Yay Ye Liye Noy.

\section{Frau Frohmann. | Marion Fay.}

The Land-Leaguers.

Pos! 8 ro, illustrated voards, 2s. each.

Kept in the Dark.

The American Senator.

The colden Lion of Granpere.

Mr. Scarborough's Famlly. Crows 8 vo, cloth, 3s. 6\%.

\section{TROLLOPE (FRANCES E.),} Novels by. Crown 8vo, cloth, 3s. 0. . each; posi kyo, illustrated boards, 2s. cach.

Like Ships upon the Sca.

Mabel's Progress. | Anne Furness.

TROLLOPE (T. A.).-Diamond Cut Dlamond. Post 8in. illus, bds., 2s.

TWELLS (JULIA H.).-Et tu, Sejane I Cruwn 8ro. cloth, 6s.

TYTLER (C. C. FRASER-). Mistress Judith. Crown $8 \%$, cloth, 3.s. 6 d.: post $S v($ ). illusirated boards: $2 \mathrm{r}$.

TYTLER (SARAH), Novels by. Crown 8ro, cloth, 3s. Gi. each; post sro, illusirated boards, 2s. each.

Buried Diamonds.

The Blackhall Ghosts.

What Sho Came Through.

Post 8vo, itustrated buitds, 2s, each.

Saint Mungo's City. | Lady Bell. The Huguenot Famlly.

Disappeared. I Noblesse Oblfge.

Beauty and the Beast.

Crown swo, cinth. 35. 61 . each.

The Macdonald Lass.

The Yitch-Yife.

Rachel Cangton.

A Honeymoon's Eclipae.

A Young Dragon.

Crown sio, cloth, os. each.

Three Men of Mark:

In Clarissa's Day.

Sir Dayid's Visitors.

Tho Poet and $\mathrm{H}$ is Guardian $\mathrm{Ang}$ Gl.

Citoyenne Jacqueline. Crown Svo, picture cloih, llat bask, $2 s$.

Tho Bride's Pass. Post 8vo, illus trated boards, 2s.; CHEAP EDIrIox: cloth. 15. net.

UPWARD (ALLEN), Novels by. The Qiveen against owen. Crown

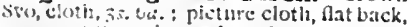
2.. ; posi (ivo, picture bruards, 2.5 .

The Phantori To:pedo-Boats. Crown divo, choth, os.

VANDAM (ALBERT D.).-A Court Tragedy. With 6 Illustrations by J. J3, LAw1s, Crown Sro, closth, 3s. 6d.

VASHTI and ESTHER. BY

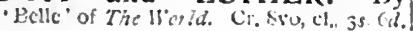

VIZETELLY (ERNEST A.), Books by. Crown 8vo, cloth, 3s.6d.each. The Scorpion.

The Lovor's Prosress.

With Zola in England. 4 Parts.

A Path of Thorns. Cruivn 8vo, cloth, 6 s.

The Kild Marquis: Life and Adventures of Armand Guerry de Naubreuil. Crow Svo. cloth. 6s.

IVALLACE (LEW.).-Ben-Hur: A Tale of the Chrlst. Crowa 8 s' cloth, 3s. isd.

WALLER (S. E.).-Sebastiani's secret. Vith o Jllusls. Cr. Sro. cl.. Gs.

WALTON and COTTON'S Complete Angler. Pott Sro, cloth, gitt, 2.s. nel : leather, gilt edges, 3s. net.

WALT WHITMAN, Poems by. Edited, with Introduction, by W. M. RusSETTl. With Port. Cr. 8vo, buckram, 6s.

WARDEN (FLORENCE), by. Joan, the Curate. Croxn 8 vo, cloth, 3.s. (k.) picture cloth, flat back, 2 .

A Fight to a Finish. Cr. $8 \mathrm{vo}, \mathrm{cl}_{2}, 35.6, \mathrm{l}$.

$$
\text { Crown } 8 \text { so, cloth, 6s. each. }
$$

The Feart of a Girl. With 8 lllusts.

What Cught Sho to Do?

Tom Dayson.

The Younfest Miss Brown.

Lore and Lordship:

The Old Ifouse at the Corner.

My Lady of Whims.

WARMAN (CY).-The Express Messenzer. Crown 8vo, cloth, 35, $6 d$.

WASSERMANN (LILLIAS).The Datfodils. Crown 8vo, cloth, is. 6 d.

WESTALL (WILL.), Novels by.

Trust-Money. Crown $8 r^{\circ}$, cloth, 3s. 4 .: pusi svo, illustrated boards, 25 .

$$
\text { Crown 8vo, cloth, 6s. each. }
$$

The Old Bank.

Dr. Yynne's Reyenge.

The sacred Croscents.

A Yery Queer Bustness.

Crown svo, cloth, 3s. 6ut. each.

A Woman Tempted Him.

For Honour and Life.

Her Two Millions.

Two Pinches of Snufi.

With the Red Eagle.

A Red Bridal. Nigel Fortescue. Ben Clough. Birch Dene.

The old Factory.

Sons of Belial. | Strange Crimos. Her Ladyship's Secret.

The Phantom City.

Ralph Norbreck's Trust.

A Queer Race. | Red Ryyington. Roy of Roy's Court.

A s cuck would haye it.

As a Man Soys.

With the Red Eagle: Porvlar

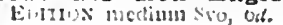


WARRANT to Execute Charles I. A Facsinile, with the 59 Signatures and Seals, $2 s$.

Yarrant to Execute Mary Queen of Scots. Including Queen Ellizabeth's Signature and the Great Seal. 2ヶ.

WEBBER (BYRON).-Sport and Spangles. Crown 8vo, cloth, 2 s.

WERNER (A.).- Chapenga's White Man. Crown 8vo, cloth, 3s, 6d.

IVESTBURY (ATHA). - The Shadow of Hilton Fernbrook. Crown 8vo, cloth. 3s. $6 d$.

WHEELWRIGHT (E. G.).-A Slow A wakenlng. Crown $8 v^{\circ} 0$ cloth. 6 .

WHISHAW (FRED.), Novels by. Crown $8 v o$, cloth, 3s. 6 d. each.

A Forbidden Name.

Many Ways of Loye. With 8 Illusts.

Mazeppa.

Crown 8ro, cloth, 6s, each.

Near the Tsar, near Death.

A Splendid Impostor.

WHITE (GILBERT). - Natural History of Selborne, Post 8 vo, cloth, $2 s$

WHITNEY (HELEN H.).-The Bed-time Book. With Illustrations in Three and Two Colours by Jessie $W$. SuItu. Royal 4to, balf-cloth decorated, 5s, net.

WILDE (LADY).-The Ancient Legends, Charms, and Superstitions of Ireland. Crown 8vo, cloth. 3 s. $6 d$.

WILLIAMS (W. MATTIEU), by.

Science in Short Chapters. Crown $8 v 0$. cloth, $75.6 d$.

The Chemistry of Cookery. Crown 8vo, cloth, 6 s.

A Simple Treatise on Heat. Wilh Illustrations, Crown $8 v o$, cloth, 2s. $6 d$.

WILLIAMSON (MrS. F. H.).-A Child Widow. Post 8vo, illust. bds., 2s.

WILLS (C. J.), Novels by.

An Easy-golng Fellow. Ciown 8vo, cloth, 3s. od.

H1s Dead Past. Crown Rro, cinth, f.r.

WILSON (Dr. ANDKEW), by.

Chapters on Exolution. With 259 lliustrations. Crown 8vo, cloth, 75. $6 d$.

Lelsure-Time Studies. With Illustrations. Crown $8 v 0$, cloth. 6 s.

Studies in Life and Sense. Whth 36 lllustrations. Crown 8vo, cloth. 3s. $6 d$.

Common Accldents, and how to Treat Them. Cr. 8vo, is.; cloth, Is. $6 d$

Glimpses of Nature. With 35 Illustra. tions. Crown $8 \%$, cloth, 3s. $6 i$.
WINTER (JOHN STRANGE), by.

Regimental Legends. Post 8vo, Iilustrated boards, 2s. : cloth, 2s. $6 d$.

Cayalry Life; and Reglmental Legends. Crown 8vo, clorh, 3s. 6d.; piclure cloth, flat back. 25 .

WOMEN OF FLORENCE, dur Ing and prior to the Clnquecento. By Prof. IsIDORO DEL LE:igo. Translated by M. G. SteEgMaxs, With Introduction by Dr. Gildo Bragl, and 2 Coloured Plates and 24 Half-tones, Large crown 8 ro, buckram, $7 s, 6 d$ net.

WOOD (H. F.), Detective Stories by. Post 8 vo. illustrated boards. 25 . each.

Passenger from Scotiand Yard.

The Englishman of the Rue Cain.

WOOLLEY (CELIA PARKER).Rachel Armstrong. Post 8vo,2s. $6 d$.

WRAGGE (CLEMENT L.).The Romance of the South Seas. With 84 Illustrations. Crown $8 \%$, cloth, 7s. 6d. net.

WRIGHT (THOMAS), by.

Caricature History of the Georges; or. Annals of the House of Hanuver. With Frontispiece and over 300 Illustrations. Crown 8vo, cloth, 3s. $6 d$.

History of Caricature and of the Grotesque in Art, Literature, Sculpture, and Painting. Illustrated by F. WV. FAIRHOLT. Crown 8 ro, cloth, 7 s. $6 d$.

ZANGWILL (LOUIS).-A Nineteenth Century Miracle. Crown 8 vo, cloth, 3s. 6d.: picture cloth, flat back, $2 s$.

Z O L A (E M ILE), Novels by. UNIFORII EDITION. Translated or Edited, with Introductions, by ERNEST A. VIZETELLY. Crown $8 v 0$, cloth, 3s, 6d. each.

His Masterplece. / The Joy of Life. Germinal.

The Honour of the Army.

A bbe Mouret's Transgression.

The Fortune of the Rougons.

The Conquest of Plassans.

The Dram-Shop.

The Fat and the Thin. I Money. HIs Excellency. The Dream. The Downfall. Doctor Pascal. Lourdes. Fruitruiness. Rome.

Paris. York. Truth.

Poptlar EDitions, medium 8vo, 6d, each. The Fortune of the Rougons.

The Dram-Shop.| Paris. I Monev. Lourdes. | Rome. The Downfail.

Yith Zola In Fngland. By ERxEst A. Vizetelly. With 4 Portraits. Crown $8 v o$, cloth, 3s. Gd. 




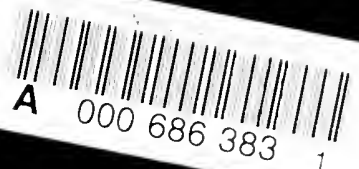


